

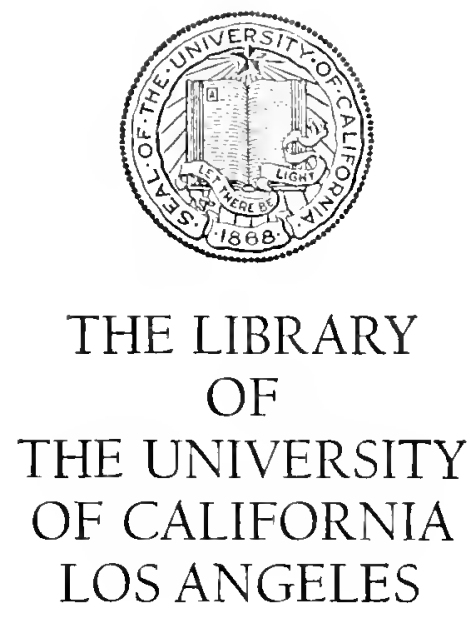

GIFT OF 


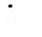




\section{THE ENGRAVED GEMS OF}

CLASSICAL TIMES. 
Ilondon: C. J. CLAY \& SONS, CAMBRIUGE UNIVERSITY IRESS WAREHOUSE, AVE MARIa LANE.

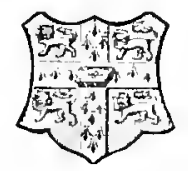

Cambritge: DEIGHTON, BELL AND CO.

ileiprig: F. A. BROCKHAUS.

Rew Jork: MACMILLAN AND CO. 


\title{
THE ENGRAVED GEMS OF CLASSICAL TIMES
}

\author{
WITH A \\ CATALOGUE \\ OF THE \\ GEMS IN THE FITZWILLIAM MUSEUM.
}

BY

\begin{abstract}
J. HENRY MIDDLETON,
SLADE PRUFESSH OF FINE ART, DIRECTOR OF THL FITZWILLIAM MUSEUM,

ANI FFLLOW OF KING'S COLLEGE, CAMIRIIME;

AUTHOR GF "ANCIENT ROME IN IS88."
\end{abstract}

CAMBRIDGE:

AT THE UNIVERSITY PRESS.

I 89 I

[All Rights reseriet.] 


\section{Cambrínge:}

PRINTED EY C. J. CLAY, M.A. ANL SONS, AT THE UNIVERSITY IRESS. 
MEMORIAE

VIRI CARISSIMI

CAROLI IVILHELMI KING. 



\section{TABLE OF CONTENTS.}

l'REFACE ANI LIST UF AUTHURITEs. P'are ix to xv.

CHAPTER I. Page I to 16.

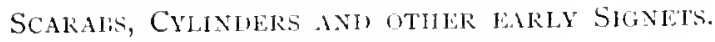

CHAPTER II. Page 17 to 34 .

Greer Gens.

CHAITER III. Page 35 to 46.

Greek Gems (Cuntineti) and etruscan scarais.

CHAPTER IV. P'age 47 to 58.

RoHAN GeMs.

CHAPTER V. Page 59 to 65.

Chane Gens.

CHAPTER VI. Page 66 to $s_{3}$.

InSCRIPTIONS ON GEMS.

CHAPTER VII. Page $s_{f}$ to g6.

INSCRIPTIONS ON GEMS (CNTINUED).

CHAPTER VII. Page 97 to 102.

TIE CHARACTERISTICS OF ANCINT GEMS. 
CHAPTER IX. I'age 103 to 120.

THE TECHNMUE OF GEM-ENGKaHNG.

CHAPTER X. Page I2I to I 28.

Gems in mediaeval times.

CHAPTER XI. Page ray to I3\%.

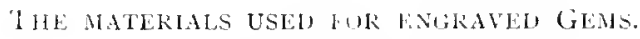

CHAPTER ẌII. Pagre 1 to to 157.

THE Materials USED FOR ENGRAYeI, Geas (CONTINUED).

\section{APPENDIX:}

Cataluge of the Gems in the Fitzwillad Museum l'age i to xxv.

INUEX. 
I the following pages I have attempted to give a brief $I$ account of the engraved gems and other forms of signet which were used by the chief classical races of ancient times. The book is intended for the general use of students of archacology, and has been written with the hope that it may in some cases lead the reader to a more detailed and practical study of this most fascinating subject.

The various tools and technical processes uscd by the ancient gem-engravers have been discussed at some length, since a close attention to these points is specially desirable as a much-needed help in the frequently difficult task of distinguishing between gems of different origin and date.

With regard to the Appendix containing the catalngue of the gems in the Fitzwilliam Museum, I have attempted to indicate the period to which each gem seems to belong, in spite of the great difficulty there is, very frequently, in attaining to anything like certainty on this point.

Even though in many cases my judgment may be erroneous, yet, on the whole, the attempt to distinguish periods of workmanship has its use, in giving the reader a notion of the gencral style and character of the gem in question.

The gems which are described in this catalogue were, with very few exceptions, collected by Colonel Leake, the 
distinguished author of valuable works on the Topography of Athens and other kindred subjects. They came into the possession of the Fitzwilliam Museum in the following manner. Iyy his will, dated Jan. 17, I859, Colonel Leake bequeathed to his wife for her life his whole collection of books, coins, gems, bronzes, vases and other antiques, with the provision that at her death, the whole collection should be offered to the University of Cambridge for the sum of $£ 5000$.

Colonel Leake died in 1860 , and his widow died in 1863 . It was then decided, by a vote of the Senate on Feb. 4, I86. that Colonel Leake's testamentary offer should be accepted and that $\$ 5000$ out of the funds of the Fitzwilliam Museum should be devoted to this important acyuisition.

The actual value of the whole Leale collection was probably double of the sum paid for it, and its value has largely increased since 1864 . The coins alone are now worth considerably more than the $£ 5000$ which was paid for the whole collection.

In 1870 a catalogue of Colonel Leake's gems was published by the late Charles William King, M.A., Senior Fellow of Trinity College, Cambridge, the well-known author of many works on antique gems, which are full of interesting matter illustrated by the widest reading and the most copious learning. At this time, however, Mr King's eyesight had begun to fail, and in consequence of that a certain number of inaccuracies crept into his descriptions which make it desirable that another catalogue should be prepared, illustrated by a photographic process which gives the actual character of each gem better than the woodcuts in Mr King's work.

Mr King's chief works on gems were the followingAntique gems, I 866 ; Precious Stones and Mctals, I865; reprinted in Bohn's Series in $188_{3}$; Handbook of engraral scons, I866; Antique gems and rings, 2 vols. 1872 ; The Gnostics and their remains, enlarged edition, 1SS7. And also a large number of articles on gems published in the 
Archarolggical Fourmal, Vols. Xin., Xix, and others. All these works are full of valuable matter, and are witten in the most interesting style.

Mr King's own collection of sems, consisting of 330 examples of various dates, was formed by him between the years $18+5$ and 1877 .

In ISSI it was sold to an American gentleman, $\mathrm{Nr} \mathrm{J} . \mathrm{T}$. Johnston, who presented the whole collection to the Metropolitan Museum in New York City. A descriptive catalogue, written by Mr King in I 878 , was published by the New York Muscum in 1882.

Mr King died suddenly in London on the $26 \mathrm{th}$ of March, I898. Of his loss as a friend it is impossible to speak"aeternum(pue

Nulla dies nobis maerorem e pectore demet."

J. IIEN. MIDDLETON.

King's College, CAMBRIDGe. 



\section{WORKS ON ANTIQUE GEMS:}

A large number of the most valuable monographs on gems are scattered through the volumes of the chicf archacological periodicals of England, France, Gcrmany and Italy; with the names of which classical students will be familiar.

Books on gems of the $I 7$ th and I sth centurics are now of but little valuc except for the rccords they supply, showing, in certain cases, that a special gem is not, at least, one of quite modern production.

The chicf works of this class are these:

Agostini, Gimme antiche figurate, 2 vols., Roma, 1686.

De la Chausse, Gemme antiche di Nichclangelo Consco de lir Chousse, Roma, izoo.

Maffei, Gemme anticke di Dom. de' Rossi collc sposizioni di P. A. Maffi;, Roma, 1707.

Stosch, Gemmat antiquac coldato, Amsterdam, I724, and the same collection described by

Winckelmann, Pierres graves du fou Baron de Stosch, Florence, 1760 .

Zanetti, Dactyliotheca, Rome, I 747 .

Marictte, Traté des ficres gratés, Paris, 1750; and Muscum Odescalchm, siate thisamus gemmamm, Romc, $175 \mathrm{I}$.

Gori, Museum Florentinum, Florence, I73 I-1762.

Natter, Traité des picrres gravées, London, I76 I.

1 The most important works in English on engraved grems are those written hy C. W. King, a list of which is given in the ['reface on page $\mathrm{x}$. 
Gori, Datyliothear Smithiona, Venice, I 767.

Worlidge, Antique gems, London, I 768.

Cipriani, Draingrs of roo gems in the Marlborough Collection. engraved by Bartolozzi, 2 vols. folio, I $780-1791$.

Raspe, Catelogue of gems cast in paste by Fames Tassic, London, 1791.

Many other large and costly works with illustrations of antique gems were published in the Isth century, but the engravings of that time give little or no notion of the real character of the gems they represent, the main object of the artist being to give a pretty picture rather than a faithful copy.

Among more recent works the following are the most valuable-

Toelken, Erklirondes Voracichniss der antitien ierticft gesehmittenen Stine, Berlin, I $\$ 35$.

Köhler, Gesammolti Schriften, horausgegeben a'on L. Stchhani, St Petersburg, i $S_{50}-\mathrm{I} S_{53}$.

Panofka, Gemimen mit Inschriften, printed in Abhandlungen der König. Akad. der Wissenschaften zu Berlin, I $85 \mathrm{I}$, pp. $385-519$.

Brunn, Geschichte der Griechischen Kïnstler, Brunswick, I \$59, Vol. II., pp. 444-637; and new edition, I $\$ S 9$, Vol. II., pp. $303-433$.

Chabouillet, Catologue des amés et pierres sraices de la Bibliothique Impériale, Paris, I $\$ 5 \$$.

Stephani and others, Compte-rendu de le Commission Tmpériale Archologique, St Petersburg, I 860 to the present time; and, dealing with the same subject, Antiquitis du Bosphore Cimméricn, St Petersburg, I $\$ 54$.

Gerhard, Gesammelte akademische Abhandlungon und hline Schrifton, Berlin, I $\$ 66$.

Muiller-Wieseler, Dcnkmälor dor alton Kunst, Theil II., Göttingen, I 869 . 


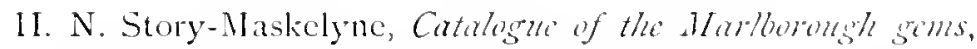
privately printed, london, i 870 .

Milchhocfer, Dic Anfünse dir Kunst in Grichendand, Lcipzigs. $1883, \mathrm{pp} .78$ to 90.

Furtwingler and others, Mykinische T'asen, Berlin, 1886.

A. 11. Smith, Catalogue of gems in the British Museum, with an Introduction by A. S. Murray, London, asss.

Other works are referred to in the following text. 


\section{LIST OF ILLUSTRATIONS.}

Page 4, fig. I ; Babylonian cylinder of c. 2600 B.C.

I'ages 7 to II, figs. 2 to I2; Various forms of "Ilittite" signets.

Page I4, fig. I3; Phoenician scarab of mixed Egyptian and Assyrian style.

Page I9, fig. I4; Glandular gem with rude figure of an ibex.

Page 19, fig. I 5 ; Lenticular gem, with two goats of heraldic style.

Pase 25, fig. I6; Satyr and wine cup; Greek gen of the 6th century B.C.

Page 26, fig. I7; Hero with bow and arrow; Greck scarab of the finest style.

Page 30, fig. I \&; Lion and stag: fine Greek work of the 5th century 1.C.

Page 4I, fig. 19; Portrait head of Eumenes 1., king of Pergamus.

lage 66, fig. 20; Jewish signet with owner's name; 9th or Sth century B.C.

Page I05, fig. 2 I ; Gem showing a man working with the drill and bow.

Page 107, fig. 22; Etruscan scarab, with rude drill-work.

Page IoS, fig. 23; Lenticular gem, showing the use of the tubular drill.

Page I Io, fig. 24; Lenticular gem showing the use of the whecl.

Page 112, fig. 25; Head of Zeus; Greek scarab of finest style, showing the use of the diamond-point.

\section{APPENDIX}

Plate I.

Greek gems in the Fitzwilliam Museum, to face p. xxvi.

Plate II.

Roman gems in the Fitzwilliam Museum. 


\section{CHAPTER I.}

SCARARS, CrLINDERS, AND OTHER EARLy SHGNETS.

IN carly times, when writing was a rare accomplishment practised by few except professional scribes or nembers of a pricsthood, hard stones or jewels engraved with a name or a device were of special importance from their use as signets, the impression of which gave that authenticity and authority to a document which in modern times is more usually conferred by a written signature. The signet of a king was commonly regarded as an authoritative symbol of his power, which he could delegate to a subject by entrusting to him the royal scal, with permission to use it: as, for example in ancient Egypt, when the Pharaoh of the time invested Joseph with vice-regal power over his kingdom, "Pharaoh took off his signet ring from his hand, and put it upon Joseph's hand," Gin. xli. 42, Revised Version. In the same way a duplicate of Augustus' signet was entrusted to a friend in Rome for use during the Emperor's absence on military expeditions; sec below, page 49; and cf. Dio Cass. Lil. 30.

It was not until a comparatively late period, about the $4^{\text {th }}$ century E.C., that engraved gems were commonly treated as personal ornaments. At first they were made and used simply for the practical purpose of signets.

SCARABS: The earliest class of signets which now cxist, with the exception of some Egyptian rings made wholly of gold, are in the form of the sacred scarabaens bectle of Egypt, the symbol of the Sun-god Ra, the Fertilizer of 
the World ${ }^{1}$. The back of the scarab is cut into the beetle form, and the signet device, usually a hicroglyphic inscription, is cut on the flat underside of the scarab. A hole drilled longitudinally through the scarab allowed it to be set in a

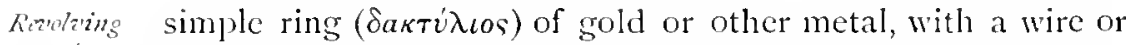
mounts. swivel passing through the perforation, so that, when required for use as a signet, the scarab could be revolved, and its flat side brought outwards and pressed on wax, clay or other soft plastic substance.

Some of the signet-scarabs which are too large for setting in a ring were worn on a string round the neck; a method which appears to have been one of the carliest ways of wearing any kind of signet.

Hatirials

It should however be noticed that the scarabs of Egypt "were made for many other purposes besides that of signets", and the majority of them are not cut in hard stone or crystal, but are moulded in clay or worlied out of the comparatively soft steatite, a vitrcous glaze being applied by the maker both to stcatitc and clay scarabs ${ }^{3}$.

In point of date the oldest scarab-signets of Egypt go back to a very remote period : examples have been found with the names of kings of the 4 th Dynasty, dating about 3700 years B.C.

In later times the scarab form of signet was adopted by the Phocnicians, the Greeks and other races, who cither dircetly or indirectly came under Egyptian influence.

cylindirs. CrLinders: another very early class of signet is the cylinder of Assyria and Babylon, measuring most commonly from $\frac{3}{4}$ of an inch to $1 \frac{1}{2}$ inches long, and about half an inch to an inch in diameter. These are not made of clay, like so many of the Egyptian scarabs, but are cut out of hard stones,

1 The scarabaeus beetle (Egyptian Khoter) was axlopted as this symbol on accounl of its moulding large balls of clay, rom like the world, in which it encloses its eggs. The heat of the sun hatches the eggs, and the young beetlen hurst forth from the clay ball.

"The great bulk of them, especially those made of poltery, were sacred charms or amulets rather than signets.

"The Fitzwilliam Museum possesses a good collection of this class of scarab): they are dencribed in the furthcoming catalogue of Esyptian ubjects in the Museum by Mr Budge. 
such as green jasper, rock crystal, chalcedony, haematite, carnclian, or more rarely amethyst and lapis lazuli. These cylinders are drilled longitudinally with a hole of sufficient diameter to receive a woollen or linen cord instead of a metal wire, and they were worn as a bracelet on the wrist, or else strung round the neck ${ }^{1}$. Thougl used primarily by the powerful races of the Eupluates Valley, these cylinder signets were not unknown among other nations, such as the Semites of Phoenicia and Palestine. and even in the carly island colonies of the Phoenicians. The "signet and the cord," mentioned in Gencsis xxxriii. Is and 25, Revised Version (or "signet and bracelets" of the Old Version) are examples of this use of the cylinder. So also in Canticles riii. 6, the phrase occurs "set me as a seal upon thine arm."

A very large number of these Babylonian and Assyrian cylinders still exist; they appear to have been used by all except the very poorest classes. They are usually engraved with the name of the owner in cunciform characters, together with figures of various deities, accompanied frequently by attendant genii or worshippers. A very favourite subject, especially among the earliest cylinders, is a deity or a king slaying a lion. The sacred tree (Hom) between two guardian beasts or winged figures of human form occurs very often. This latter is the most characteristic of the designs used by the inhabitants of the Euphrates valley; from them it was adopted by the Phoenicians, and thus spread over an area as wide as the whole range of Phoenician trade, that is throughout the whole of the shores and islands of the Nediterranean. This very early and widely popular design was largely used by the Tyrian builders of Solomon's temple, as we read in I Kings, chaps. vi. and rii., and in 2 Cleronicles, chaps. iii. to $v$., where the derice is mentioned as being repeated again and again in various materials under the name of "the palmtree and the winged cherubim?"."

I In a few cases the cylinfler is mounted on a metal pin with a boss at each end to hold it fast, but this is quite exceptional.

2 The Phoenician scarab illustrated in ligr 13, page 14, has examples of the winged Cherulim of Assyria.

Desisns on olinition.

$l ' a l m+l$ H'ct $^{\prime}$ 
The cylinder signet of a private person commonly has a figure of his special deity, and often a representation of the owner standing by in the attitude of worship. The inscription usually gives the name both of the deity and of the owner: as, for example, a fine haematite cylinder in the British Museum which is inscribed thus, "Abum-ilu the scribe, son of Nur-Martu, the servant of the grod Martu (Rimmon)."

Dates of ijlintios.

Examples of these cylinders exist extending over a very wide period of time, from about 2600 B.C. to 200 B.C. or even later. Some of them are very fine examples of ancient Oriental art, designed with much spirit and executed with wonderful minuteness and delicacy of touch in the highly decorative and conventional style which is common to all the best Assyrian sculpture, whatever its scale may be.

Those of early date are the finest and most powerful in style; as, for example, a magnificent Babylonian cylinder of jasper in the British Nuscum, the signet of a scribe, dating about 2600 I.C., on which is cut a very noble figure of the deified hero Gistubar strangling a lion ${ }^{1}$ : sce fig. I.

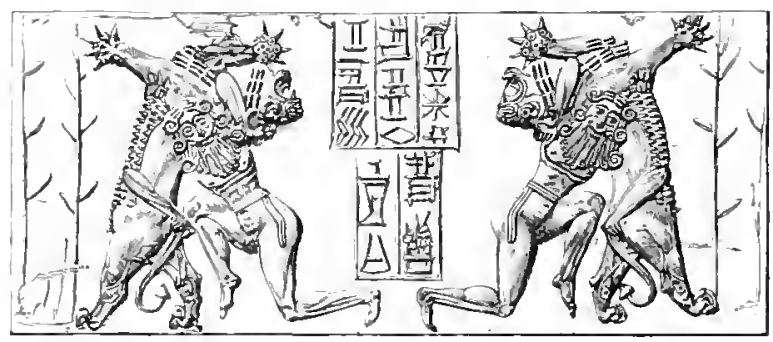

Fir. 1. Impresion from an early Ihaylonian cylinter of the finest style: with the name of the owner and his deity in cuneiform characters, between two representalion. (reversed) of the same sulject-Gistulbar strangling a lion: real sise.

Siargon t. The equally fine cylinder of Sargon I. (in Paris) is closely similar in style to this, and seems to be the work of the same engraver. The very decorative treatment of the hair, both of the heroes and of the lions, is specially noticeable.

\footnotetext{
1 On the fine cylinders of this early period the most frequent subjects are Gistular and his companion I lea-bant slaying lions or bulls, sometimes separately ancl somelimes togelher, like I Ieracles ant Iolaos in early Greek art.
} 
The date of Sargon I. is not known with any certainty. According to some archacologists his reign was as early as about 2800 13.C. If so, the date of the cylinder shown in fig. I would probably be two centuries carlicr than is suggested above.

In later times, under the Persian conquerors Darius and Nerxes, Babylon produced cylinders of very minute and delicate workmanship, showing the influence of Greel art, but inferior in spirit and vigour to the engravings of earlier date. The most remarliable example of this, clating from the end of the 6th century 13.C., is the sisnet of Darius Hystaspes, a jasper cylinder engraved with the king in a chariot hunting lions, and with the cunciform inscription, "I am Darius, the Great King" thrice repeated in the Persian, Median and Assyrian languages. This also is in the British Museum. Lastly, the cylinders of the $3 \mathrm{rd}$ century i.C. are very rude in design and of the coarsest, most clumsy workmanship.

The cylinder form of signet was also used, though not commonly, in Egypt. The Egyptian cylinders are, as a rule, not made of crystal or jasper, but of pottery or steatite covered with a blue glaze, exactly like the scatabs: on them are cut or moulded, not large figure subjects, but hieroglyphic inscriptions. They appear to have been usually worn round the neck.

The custom of wearing the cylinder-signet as an ornament appears to have led to the use of plain unengraved cylinders, strung on necklaces like large beads. A great many of these in rock-crystal and glass have been found in the tombs of Camiros in Rhodes and elsewhere in the Greek islands and sea-port towns.

When used as a signet the cylinder was rolled over a soft lump of wax or clay, which was thus flattened out over the surface destined to receive the seal, and at the same time received the impress of the cylinder ${ }^{1}$. The fine clay used for sealing not only with cylinders, but also with other forms of 


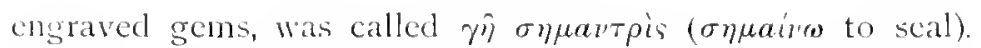
Herodotus (II. 38) describes the Egyptian priests using this clay to mark with their signets the animals which were accepted for sacrifice. Many examples of these clay seals lave been found in Egypt, used for many different purposes, both religious and secular; sec page 37 .

stams on The method of sealing by rolling an engraved cylinder fottiry. over soft clay appears to have suggested a form of decoration, which was largely used by the potters of Etruria for the shoulders of their colossal jars (fithoi), of which a great number of examples, mostly dating from the 6 th or 5 th century 13.C., still exist.

The patterns on these were moulded in relief on the plastic clay, after the jar was "thrown" on the wheel, but before it was fired, by rolling along a cylinder or disc, on the edge of which the design was sunk. These dises were usually about 9 or Io inches in circumference, and therefore the pattern repeats regularly at that interval.

The subjects on these bands are rows of animals, Tritons and the like, often very similar in design and style to the sculptured reliefs on the architrave from the Temple at Assos, now in the Louvre.

Cones. CONICAL sIGNETs: in Assyria, even at an early period, signets of conical form, of the same materials as the cylinders, were sometimes used. These cones, with the device sunk on the broad end, were pressed on rounded lumps of clay in which a piece of string was embedded for the attachment of the seal to a document. The mediaeval system of scaling was similar to this, pendant seals of wax being fastened to parchment deeds by a cord embedded in the wax. Many of the so-called Hittite signets are conical in form, see pages 7 and 8 , figs. 2 and 3 .

The later Persian signet-gems, from about the time of Alexander downwards, were also rery commonly cut, not in the form of eylinders, but of truncated cones. These belong to a period of artistic decadence, and are usually poor in design and coarse in exccution: a great contrast to the magnificent vigour of the figures on the carly Assyrian 
cylinders of about 2600 I.C., and also to the delicate minuteness of the l'ersian cylinders of the 5 th century li.e.

"HitTite" (iEls, so-called.

The name "Ilittite" has been given to a very rumarkable and primitive class of signets, which appear to have been made by some powerful race, whose infuence extended throughout a considerable portion of Northern Syria and Asia Minor, at a very early period, perhaps fifteen or sixteen centurics 1.C.

These signets do not, strictly speaking, belong to the class of gems; as they are mostly cut out of the softer stones, such as steatite and fine limestones, marbles and serjentine of various colours-black, white, red and brown: a few are on an inferior variety of pale green jasper. They are however of very great interest to the student of early gems, since many. of them appear to be prototypes of the lenticular "Island gems;" and others of various forms seem to show the gradual modification of the cylinder into the cone-signet, and the further change from the cone to the hemispherical or annular seal.

The variety of the shapes of these "Hittite" gems is very sreat, but none of them appear to have been set in rings; all were suspended in some way by a cord, probably round the neck of the owner.

The following are the chicf forms of these signets:

I. Rude cylinders of the Assyrian shape.

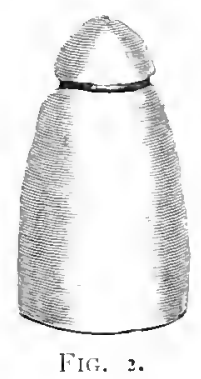

2. Cones, with the principal device on the base, and the hole or groove for suspension near its smaller end; see fig. 2.

1 For an account of cylinders and other Oriental gems, sec the Vogke 
If the cone is pierced the hole is drilled at right angles to its axis, not longitudinally as in the cylinders. Some of these conical signets are engraved with figures, not only on the base, but also round the sides of the cone, thus forming a link with the cylindrical shape of signet.

Another variety of the conc is very short in proportion to its diameter, almost hemispherical in shape; see fig. 3 .

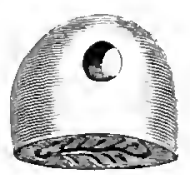

FIG. 3 .

This variety, with its hole for suspension enlarged, leads to the ammlar form of signet.

3. A ring-like stont, in which the perforation is not large enough for the signet to be worn on the finger; it must therefore have been suspended in the usual way by a cord; see fig. 4 .

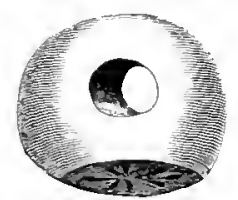

FIG. 4 .

A further development of this shape, which rarely occurs,

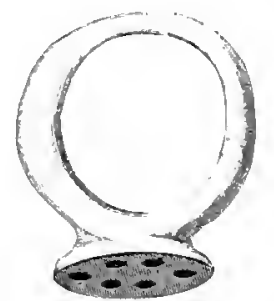

FIG. 5.

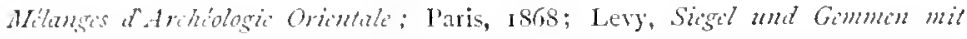
"romaische'se. Inschrift'n, Breshu, 1869 , and Menant, Kuhorhes sur la glyplinut Oricmale; Paris, is\$6. 
is an actual finger-ring cut out of stone, with one side flattened to form the bezel for the signet device; see fies. 5 .

4. Another form among these signets is a retangular tablet, flat on the lower side where the device is cut, and shaped like a low-pitched roof on the other side, giving in section a triangle with one obtuse and two acute angles, the latter being rounded off; see fig. 6 . The perforation runs longitudinally through the tablet.

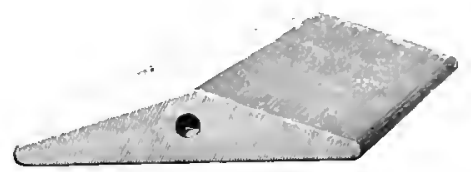

Fis. 6.

5. A great many of these signets have the bean-like, fian lenticular shape of the so-called "Island gems," usually with a longitudinal perforation, but sometimes, instead of that, with a groove cut all round the rim of the disc, allowing a cord or wive to be securely wrapped round the signet.

A few of the conical signets also were suspended in the same way (see fig. 2), not by means of a hole drilled through them, but by a groove cut round the smaller end of the cone. Out of this form the handlat signt was developed, class no. 7 , described below.

6. Another less frequent variety seems to have developed out of the cylinder by slicing its round sides off, making it square or polygonal in section, and thus giving four or more surfaces for separate devices, instead of the continuous band of the cylinder.

7. Handlad signets; a large proportion of these signets are cut into various shapes with handles worked out of the same picce of stone. The flat surface where the device is cut is of many forms, circular, oval, square, rectangular or lobed. The handles too vary greatly in shape, some being short projections, only sufficient to receive the perforation for the suspension of the seal, see fig. 7 . Others have tall handles, in some cases moulded into ornamental forms at the place 


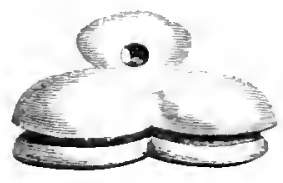

Fis. 7.

where the corl passed through the handle: see figs. 8 , 9 and 10.

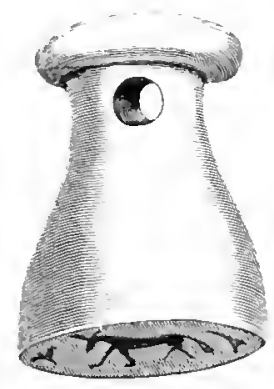

Fig. S.

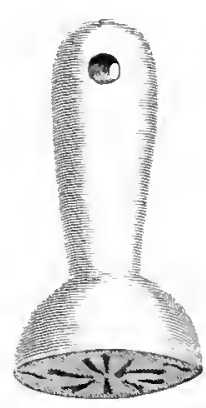

FiG. 1).

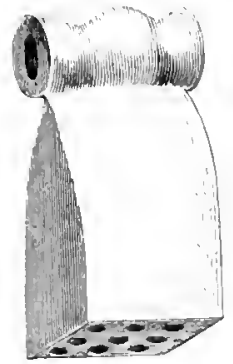

Ifiti. 10.
Chestery collection.

Like the seals shown in figs. 2 to 12 , the finest and most claborate of these landled signets is among the very fine collection of "Hittite" gems, the most important in the world, formed by the Rev. Greville Cliester, and now in the Ashmolean Muscum at Oxford.

This is a large cubical signet cut out of a fine piece of black magnetite, with minutely engraved figures of deitics on five sides of the cube. The pierced handle is elaborately moulded, in a fashion which suggests metal-work rather than hard stonc. The workmanship of this remarkable signet is very delicate and skilful, a striking contrast to the usual very coarse figures on the "Hittite" seals. Though rescmbling in general form the handled signets of the "Hittite" class, it is most probably the work of a Phoenician gem-engraver: it was found in or near Antaradus on the coast of Phoenicia ${ }^{1}$.

1 It has been described and illuntrated by Professor sayce, Aith. Fourn. Vol. xilv. 1887, P.? $3+7$ to 350 . 
The devices on the "Hittite" signets are usually extremely rude and coarscly cut, most of the sinking being done with large drills and whecls, with but little help from subsequent re-touching.

Animals, such as goats and stags, and others too coarsely drawn to be distinguished, together with very rude human figures frequently occur.

Other signets have simple geometrical patterns, formed mainly by combinations of whecl-cut straight lines, (sec figs. I I and 12) closely resembling the semé patterns which fill up

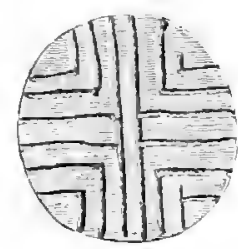

Jil. II.

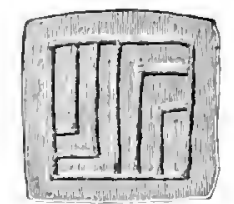

FIG. 12,

the backigrounds of early Greck pottery of the so-called "Oriental" and "Dipylon" types. Some of these signets have no more claborate device than rows of drill-sunk holes, like the sixes on ordinary ivory dice; sce figs. 5 and 10.

There is however in the Chester collection (Ashmolean Muscum) one remarkable circular signct, with a rounded

handle cut out of hard whitish limestone, the device on which is a much more skilful picce of work. Within it circular, hatched border is a double-hcaded cagle "displayed," very like the heraldic eagle of mediacval Austria, designed with much spirit and decorative power. The same device occurs on some of the rock-cut relicfs of Asia Minor, which have been attributed to the same "Ilittite" race. This double-headed cagle was adopted as his badge by the celebrated Moslem conqueror Saladin, who may possibly have taken it from some of these carly reliefs. It is to be secn over one of the gates of the citadel of Cairo, which is said to have been built by Saladin, or more probably by one of his successors. It certainly was copied and introduced into Westem Europe by the Crusaders of the 12th century A.l., 
and thus the familiar "displayed eagle" of Austria may have originated in the device used by some chief of the once powerful eastem race, which used these very interesting and primitive signets.

The name

With regard to the word "Iittite," as applied to signets "Hittili." and sculpture of uncertain date and origin, it should be observed that the name is a somewhat misleading one, since although monuments of the people who are so called have been found in the country of the Hittites, that is, in the district inhabited by the Canaanites of Coele-Syria, yet they are also largely found in regions with which, as far as is known, the true Hittites had no connection.

Nevertheless, the name which was given to this class of objects at their first discovery may be provisionally retained, until further researches have led to more accurate information on the subject.

\section{Phomenichan Gems.}

E.gy $\operatorname{los}^{-}$ Phoinitian scarabs.
A large number of scarabs made of pottery or steatite in the Egyptian form, but with almost meaningless copies of Egyptian designs with blundered hicroglyphic inscriptions, coarsely executed, are found in Rhodes, Cyprus and other islands of the Mediterranean; some of them apparently are as early as the I th $^{\text {th }}$ to the roth century B.C. These imitations of Egyptian work were probably made by Phoenician settlers ${ }^{2}$. In some cases these l'hoenician copies are made of foste or glass, and have the back simply rounded, instead of being shaped like the sacred beetle, a form which is usually called the scarabacoid, from its having the general outline without the detail of the true scarab.

1 I have to thank Mr A. J. Erans, keeper of the Ashmolean Museum, for ample opportunity to examine the gems at Oxford, both those in the Museum, and in his own very valuable privale cullection, and also for many useful suggestions on the subject.

2 The Fitzwilliam Musenm possentes a good collection of these "Island sciarals." 
No. 3 in the Catalogue of the Fijtzwilliam erems, from Camiros in Rhodes, is a grood example of this class (see 1'l. I. ), and, though small in scale, it is a characteristic specimen of Phoenician art, which most commonly combines the types of Assyria and of Egypt, fusing them into one design, with very little admixture of any forms which are of purely Phocnician origin. In other cases Phoenician gems are either wholly Ligyptian or wholly Assyrian in style: and even when Phoenician deities are represented, such as Baal-Melkarth or Baal-Moloch, they are usually treated to some cxtent after the fashion of either Egypt or Assyria.

One remarkable signet in the Ashmolean Museum at Oxford consists of a steatite scarab of Egypto-l'hocnician sty.le, set in an open bronze frame with a small ring for suspension, very much like a form of seal which was commonly used in the last century. In most cases, however, the l'hoenician scarabs which, like those of Egypt, have a longitudinal perforation, were set in a swivel mount, not in a handled setting.

In later times, from the Sth to the $4^{\text {th }}$ centuries I.C., a large number of scarabs and scarabacoids of very superior workmanship were made by the l'hoenicians, both for their Iatcr. Mocrician scarralss. own use and for purposes of trade. These gems, engraved in the harder stones, such as jasper, chalcedony and carnelian, are commonly found in Phoenicia itself, throughout Syria, and in the islands of the Nediterranean.

Some of these scarabs have engraved devices of great beauty and most delicate execution, arranged and treated with that remarkable decorative skill for which the l'hoenician artists were so celcbrated. The finest of these, cut in chalcedony or sard, have Esryptian deities and sacred symbols arranged, not with any special meaning, but simply so as to fill up the space in the most decorative and graceful way. One or two examples in the Ashmolean Muscum are among the finest which exist: they were brought from the coast of Phocnicia by $\mathrm{Mr}$ Greville Chester, and probably are considerably carlier in date than the scarabs from Tharros. Their minute workmanship and very high finish is as re- 
markable as their graceful design. Fig. 13 shows one of the

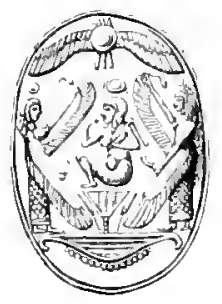

FIG. T3. Phoenician scarah of exceptionally dclicate workmanship, dating problally from the 8th century B.c. The revice consist of various sacred Egyptian and Assyrian symlol, arranged, withoul regard to meaning, simply as a decomtive device. In the centre is the Ligytian god llorus seated on a lotum fluwer, between two ungerl cherulim of Asurtian style: at the top is the wingerl orl of the sun, the symbul of the sun-goal ka. One and a half times the ral size.

Tharros sarabs. finest of these, with derices of Egyptian and Assyrian style arranged in a very decorative way, and most delicately worked in all its details.

One of the finest collections, now in the British Nuseum (nos. 155 to 221 ), came from the cemetcry of the Phocnician colony of Tharros in Sardinia, in most cases associated with objects which range in date from the 5 th to the 3 rd century 1.C. It is howerer more than probable that in some cases the scarabs are much older than the date of the tomb in which they were buried.

These later Phocnician scarabs frequently liave, in addition to the carlier designs borrowed from Egypt and Assyria, other subjects and forms of purely Greck origin; the tide of influence having turned during the days of Phocnician decadence, with the result that Phoenician art was modified by that of the Greeks; whereas some centuries earlier it was Greck art that received the infuence of Phocnicia.

No. $f$ in the Fitzwilliam collection is a specially interesting cxample of a scarab of this later type; it was found in a Greek tomb in the island of Acgina, and is inscribed with the name of its owner Kreontidas; see below, page 67. The design on it, the sacred beetle with outspread wings, is of purely Egyptian origin and the whole character of the scarab 
closely resembles some examples which are certainly of l'hoenician workmanship. It is however possible that it was the work of a Greek engraver settled in the I Jellenic trading city of Naukratis in the Delta of the Nile, where many objects of Greck workmanship but of Egyptian style have been found. Nothing is more difficult than to attain to any certainty cither as to the date or the origin of works of art of this class. As is usually the case with the art of Oriental races, the sime hieratic forms survive for many centurics without any scrious alteration; and even technical peculiarities and details of style remain unchanged for very long periods.

In the later class of Phocnician scarab-gems the design is very frequently surrounded by a peculiar border usually called Grilloilh the "cable border," or in French the guillecte. This ornament evidently originated in a sort of plaited design, forming a series of circular loops, which is one of the commonest patterns used in the carly sculpture, painting and jewellery of Myconae and other primitive Hellenic sites. It survived in Greck art on painted vases, and as a sculptured decoration for buildings, throughout the whole period of Greek autonomy. Both as a painted and as a carved pattern it occurs very frequently amoner the architectural fragments of pre-l'ersian date, which have been recently discovered on the Acropolis of Athens. In most cases, when used as a border for scarabs or scarabaeoids, the pattern has lost its curved lines, and loas degencrated into a band with a succession of straight or sloping cross strokes, mainly owing to the technical difficulty of cutting a curved as compared with a straight line on a hard stone or jewel'.

A similar suillocke border occurs on the large thin didrachms of Metapontum, Sybaris and other cities of Magna Borlers on coins. Graccia during the 6th century 1.C., those, that is, which have an incuse design on the rewerse.

Among the Sardinian scarabs found at Tharros and others of that type a great many have been found in their original

1 Owing to its frequent occurrence on the scarals found in the tombs of Etruria, this stillded patlern was once commonly called the "Etruscan lmorder:" it is not however a design of Elulcan origin. 
Hounlat searals.

Collations of scaralis. mounts; this is usually a simple gold swivel-ring, which allows the scarab to revolve on the wire which passes through the longitudinal perforation. In some cases the scarab itself is fixed in a golk mount or border of very delicate workmanship, which, of course, revolves with it.

In the 6th and 5 th centuries P.C. and even later, signets of cylinder form, usually in magnetite, crystal, or chalcedony, were made by the Phoenicians, and engraved with figures of Assyrian style.

Later still, during the extreme decadence of Phoenician art in the $4^{\text {th }}$ and 3 rd centuries 13.C., signet-gems of conical form, pierced for suspension through the smaller end of the cone, were commonly used.

The device engraved on the base of these cones is usually of the rudest and coarsest workmanship, a remarkable contrast to the very beautiful engraved scarabs made by the l'hoenicians some centuries earlier.

With regard to collections of Phoenician gems, those in the British Museum and in the Ashmolean Museum have been already mentioned. A very fine collection of scarab gems from tombs in Phoenicia and Syria was made by the Duc de Luynes, and was presented by him to the Bibliotheque Nationale of Paris.

Many Phoenician gems are illustrated by Perrot and Chipiez, History of Art in Phoenicia, 1885 (translation), Vol. I1. p. 227-260: see also Cesnola, Cyprus, I877, l'l. XxxXLI; De Vogités Mólanges d"Arhíologic Oricuterle has been already refered to. A good description of Oriental cylinders and cones is griven by Perrot and Chipicz, History of Art in Chaldate and Assyria, ISSt (translation), Vol. 11., pages 251 to 280 . In the main the literature of this subject is scattered through the pages of many different archaeological periodicals, chicfly published in Germany and France. 
CIAPTER II.

\author{
GRIEK GEMS.
}

Anoxir the carliest signets found on I Iellenic soil, though clearly not of Greck workmanship, are the massive gold rings Gold found in the tombs of Mycenae, which have figures of Oriental or ligyptian type decply cut on the broad gold bezel of the ring. The date of these is certainly not later than the 12th century B.C., and may possibly be earlicr. As they are cut on metal, not on hard stoncs, they do not (strictly speaking) come under the class of gems. In style they are very different from the gems which were found with them, and it is most probable that these gold signets were not the productions of native artists, but were Oriental imports. They are remarkable for the great size of the grold bezel, and for the complicated and pictorial chatacter of their devices, very unlike the simplicity of carly Greek gems.

On one is cut a hunting scene of very Assyrian character; two men in a two-horse chariot pursue a stas, at which one of the hunters is aiming an arrow. Another of these rings has a Rins: from Myenat. battle scene, in which the figures resemble those on the elaborate bronze daggers inlaid with gold from the same tombs within the Acropolis of Mycenac. A thirel is quite different in style, being more like mediacval or modern llindoo work than the production of any classical country. The subject is this-a female deity in Oriental costume is seated under a tree; two women and a girl present flowers to her. The field is filled "lp with various scattered devices. The whole is bad in drawing, and weak and spiritless in design-very

il. 
unlike the vigour of the figures of Assyrian style on other works of art from Mycenae.

Though sunk on a gold bezel, the design is sharply cut with gem-engravers' tools, cxactly as if the work had been on a hard stone, instead of on soft, unalloyed gold.

Nyerat In addition to these gold signets, a considerable number siths. of engraved gems were found at Mycenae. These were of the class described in the following section, namely, gems of lonticular form, cut on various hard stones and crystal.

Recent discoveries in Egypt have shown that pottery of exactly similar type to that found at Mycenae was imported into Egypt about I 400 1..C.; this is a valuable piece of evidence with regard to the probable date of the gems and other objects found in the Acropolis of Mycenae.

"ISIAND GEMs:" examples of the earlicst class of engraved gems of Greek workmanship have been found in great numbers, within recent years, on many early Helienic sites, and more especially in the islands of the Aegean Sea, hence their usual forms designation of "Island gems." Their chief peculiarity is that "Istant they are engraved on rounded pebble-like stones, mostly shaped like a circular bean (lonticula), and hence called "lenticular gems;" less frequently they are of oblong form, like a bluntly pointed oval. Stones of this form are usually called "glandular gems" from their resemblance to the ordinary lead sling-bullets (glandes). These two forms appear to be referred to by I'liny (Hist. Not. xxxvil., 196) when writing of the favourite shapes for gems, engraved or plain, "Figura oblonga maxime probatur, deinde quae vocatur

Phate I. lonticula." Nos. I and 2 in the Fitzwilliam catalogue are examples of the glandulur form, with characteristic animal devices; see also fig. I 4 from a glandular gem in the British Museum. They are always pierced with a hole drilled longitudinally through them, but in many cases they are too large to be set in swivel-rings, like the scarabs, and were probably worn by a string round the neck.

These shapes seem often to have come naturally from the form of the nodule of chalcedony or the water-worn pebble, which was polished, and had the signet device engraved on it, 
with very little cutting away of its matural suffice. This is suggrested by a common Greek word lised for engraved

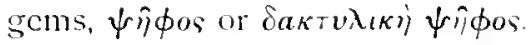

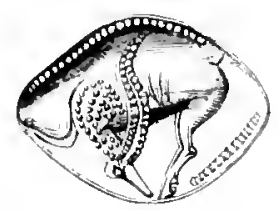

FIG. If. Characterintic example of an early grandular sem, representing the Iong-horned gonat or ibes, which inhabited the montain of Crete and ofluer inlands, cut in steatite. The use of the drill is evident in forming the borter, and the hir and horns of the animal, which appears to be dead or wounded: rial size.

Gems of this type must have been common during the Homeric period; and Pliny (Hist. Nat. xxill. I2) is wrong in arguing that, becausc llomer does not mention the use of signets, therefore they were unknown among the Grecks of the Homeric age.

The devices cut on these carly Greek gems consist chiefly of animals, such as lions, goats, decr, bulls, eagles, dolphins and others, very frequently arranged in a sort of heraldic Farliest way-two similar animals being set face to facc or backi to back, forming a stifly conventional design like the beasts

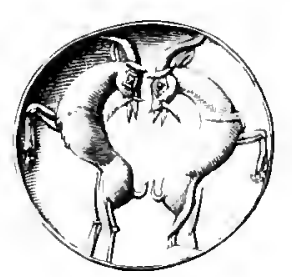

FIG. 15. Characterintic example of a lenticular gem of heraldic type, cut in

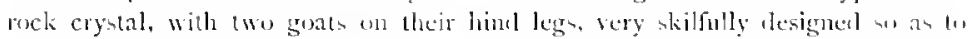
vecupy fully lhe whole area of the gem; linit. Mun. No. 57 : real size.

sculptured orer the "Lion gate" of Mycenae (sce firs. 15 and fig. 23 at page 108\%. Somewlat similar animals of heraldic character occur very commonly on the round shiclds of

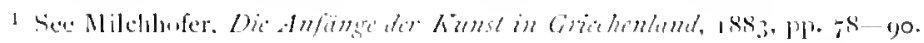


warriors on Greck painted vases of the 6 th and 5 th centurics I.C.

These "Island gems" are obviously of various dates, from the Bronze Age of Mycenac and Tiryns down to the 7th or Gth century B.C; they are most commonly cut in stcatite, but

Orinfal style. harder stones are also usce. In style they are usually rude and coarscly worked, showing little artistic refinement, but their designs are frequently very decorative and well arranged to suit the shape of the gem. In many cases a very distinct Assyrian influence appears, some of the lenticular gems having figures which are rude copics of those on the cylinders of Babylon and Assyria, probably owing to the trade and artistic influence of the Phocnicians. The earlier examples of the lenticular and glandular gems seem, like the pottery of Mycenacan type, to have been produced not only in the Greck islands, but also all along the cstensive coastline of Hellenic territory, where a cortain unity of artistic design seems to have prevailed in spitc of the wide cxtent and scattered position of the different portions of these maritime colonies and settlements.

One of the fincst lenticular gems of this class, in the collection of $\mathrm{Mr}$ A. J. Evans, at Oxford, is remarkable from being cut out of the fine green feldspar or basalt from $\mathrm{Mt}$ Taygutus in Laconia, which was so largely used for decorative purposes by the Romans of the Empirc-the marmor Leretdatmoninm of Pliny, Hist. Nat. Xxxir. 55.

The device on this remarkable signet, which, judging from its material, was probably cut in the Peloponncse, is a bull, and, bchind it, that curious monster resembling a sea-horsc which frequently occurs on works of art of this carly type. The exceptional material in which this $\mathrm{gcm}$ is cut is strong evidence in favour of its being the work of a Laconian artist, as it is very improbable that a piece of basalt from Taygetus would have been exported for usc at any far-away place. The British Muscum possesses threc or four gems of similar style cut in the same stone.

A large number of fine gems of the carly lenticular class, probably of local fabrique, have recently been discovered in a 
bee-hive tomb of the Mycenac type at Baphion, near Sparta: they are ielentical in design and technique with those found in Baphion the Greeli islands, at $\mathrm{N}$ yeenae and elsewhere on 1 leflenic soil:

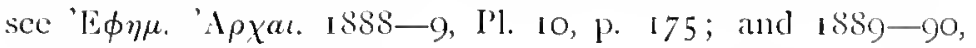
Pl. 10, 1). 163.

The commonest material used for the "Island gems" is steatite (soajstone), but some of them are cngraved on much harder stones, such as rock crystal, carnelian and chalcelony. The finc lenticular gem, for example, which is shown in fig. 15, is cut out of rock crystal of very good quality, and that shown in fig. 23 is of carnclian; sec Brit. Mus. Cort. of Goms, Nos. 57 and 106 . It evidently was not, as was the case with the Ilittites, on account of defective technical slill that the softer steatite was so often selected by the earliest Greek gem-cutters. The very bold and spirited character of many of the designs which are cut on very hard materials shows a complete command of the most effective tools, such as the engraver's whecl and drill-instruments which in shilful and patient hands will work even more refractory stones than rock crystal or carnelian.

\section{LATER GREEK GEMS.}

In the 6th and 5th centurics 1:C. Greck gems were usually cut in the scarab or scarabacoid form, partly, no doubt, on account of the commercial intercourse with Egypt, which was fostered by the Greek settlement at Naukratis in the Delta, a town which appears to have been at the height of its prosperity during the 6th century lic.

A large number of the existing gems of this time, mostly in the form of scarabs, have been found in the tombs of Etruria, whither they must have been exported in large number, by Greck and Phocnician traders.

It is noticcable that scarabs were used by the Grecks, not only for signets, but as personal ornaments. Antiphanes, an Athenian dramatist of the 4 th century 1.C., in his Fivetia ornamints. (quoted by Athenacus, Dipn. xi., $4^{8}$ ad fin.) mentions the

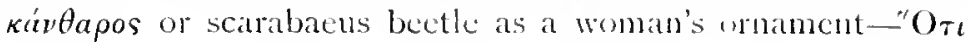




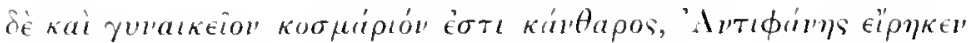
El Botwria-but no indication is given of the material of which the scarab was made.

Staluith with scarab.

Land of Solan.

Cf. ptise $3+$

Sinls as platires.

That the scarabaeus was an ornament worn also by men is shown by a fragmentary statuette in marble about ten inches high, from Cyrene, now in the British Museum.

It is a draped male figure of the Asklepios type: round the neck is a cord or necklace from which hangs a pendent in the form of the sacred beetle, with long outspread legs.

The importance of the signet-gems of this period, as a means of securing property and giving authenticity to documents, is borne witness to by Diogenes Lacrtius (1. 57) who state's that one of Solon's Athenian laws (about 600 li.C.) forbade gem-engravers ( $\delta a \kappa \tau v \lambda \iota \gamma \lambda v \phi o i)$ to keep an impression of any gem they had sold, for fear of another being made exactly like it.

Among the Greclis it appears to have been the custom for men to send impressions of their signets to give authenticity to messages, or as pledges for a bargain. The former use is mentioned by Sophocles (Trachin. 6I 4),

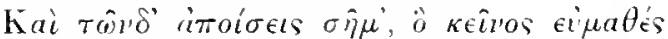

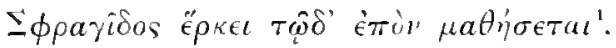

Compare also Euripides, $T h /$. A ul. 155.

Plautus, in his Psemdolus, mentions how the Macedonian soldier Harpax, when buying a slave-girl, deposited with the first instalment of money an impression of his signet (symbolum), as a pledge for the completion of the bargain. And again when he forwarded the rest of the money he sent a letter with another seal from his signet to testify that he was concluding the transaction; see Psemt. II. ii. 53 and 15 . ii. 44 .

Among the later Greeks and also among the Romans it was not unusual for the writer of a letter to state at the end of it what device it was sealed with, as a security against the letter being opened and re-sealed.

1 On this use of the woml ofjua for a signet derice see the inscription on a scarab given at page 6 . 
An example of this is cuoted in the Appendix, Cormlegm of Fitsalliam Gims, no. 2 p. iii.

In one of the letters to the Emperor Trajan written from Nicomedeia by Pling the younger while he was Propractor of the province of I'ontica, IO3 to IO4 A.D., we have another instance of this precaution.

Pliny states that he delays sending to Rome a certain prisoner named Callidromus in the hope that a gem may be found which, the prisoner asserted, had been stolen from him.

The gem was engraved with a portrait in royal robes of its former owncr, Pacorus, ling of l'arthia, whose slave Callidromus had been.

Pliny concludes by saying that he sends with the letter a nugget of ore, said to have come from a mine in Parthia, and that the packet is sealed with his own signet, the device on which was a quadriga: sce Pliny, Epis. X., 74 (16).

The talismanic rings, with devices of magical curative or protective power, which the Romans were so fond of, were not so largely used among the less superstitious Grceks; but such things were not unknown. Aristophanes (Phut. S83) alludes to signets which were a safcgurd against poisonous reptiles, when he mentions the Fust man's ring, which would protect him against the venom of the public informer-

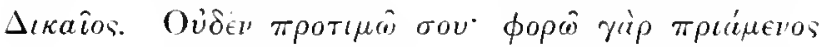

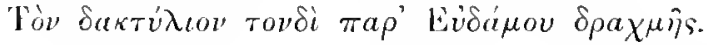

Again in a fragment of a play by Antiphancs (quoted by. Athenacus, Deipn. 111. $96(123)$ ) the miser says

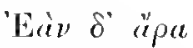

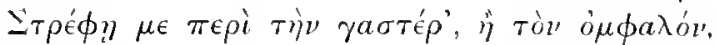

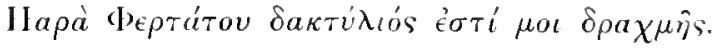

These rings, which only cost a drachma, must have been set with fasti, not real gems.

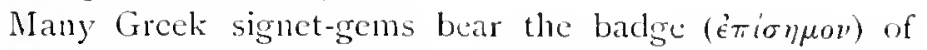
the owner, a sort of heraldic charerc which was used to distinguish between various individuals of the same name. Thus we find on the celebrated inscribed bronze plates from

litlit) 10 Trajaln.

linvi: sistict.

Talimian sisuls.

Personal leedises. 
Ioraklaca in Magna Graecia (Tabulat Heraclatenses) each matgistrate's name is followed by the name of his distinguishing badge, such as a dolphin, an ear of wheat, a bunch of grapes or the like.

Bialites on Grects coins.

fioman dimarii.

Greek i'ase's.

Subjets ont gems.
On Greck coins, from the th $^{\text {th }}$ century B.C. downwards, magistrates' names are very frequently indicated by the addition of their exionpa to the usual device either on the aberse or rearse of the coin.

It is probable that in some cases the name of the artist who engraved the coin-die is represented by a symbol of this kind, instead of by an inscription or monogram, but no example of this can (as yet) be pointed out with any certainty. Great skill and taste are frequently shown by the way in which the badge of the indiridual is combined and blended with the main design on the coin.

So on the early Roman denarii of the third century I.C., before the actual name or monogram of the Mint official was used, the identity of the magistrate was indicated by some object which he used as his device, placed in the field of the reverse by the side of the usual figures of the Dioscuri on horseback.

Greek vases, especially those of the 6th and 5 th centurics 13.C., have countless examples of warriors bearing on large round shiclds their personal heraldic badge; cf. Aeschylus, Seft. con. Thel. 384 , and 427 .

Some very beautiful and exquisitely minute examples of these heraldic shield-devices are to be seen on that wonderful little vase from Thebes, which was given to the British Nuseum by the late Malcolm Macmillan. The principal band on the vase has a row of fighting warriors, each bearing a derice on his circular buckler. See Four. Holl. Stud. Vol. XI., I890, Plate I. and p. 167 .

The subjects on Greek gems of the 6th to the 4th century I.C., are very largely scenes from poems of the Homeric cycle, and the achievements of divine heroes, such as llerakles, Theseus and Perseus, and also athletes in various pustures. Dionysiac subjects also frequently occur-Satyrs, Fauns, Macnads and the god Dionysos himself. Heads or 
busti on gems appear to have been rare till abont the culd of the 5 th century li.c.

lig. 16 show's one of the finest known gems of archaic

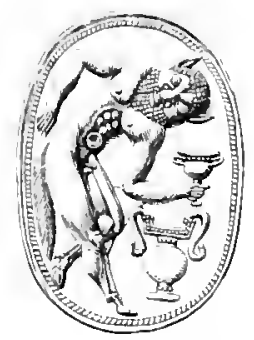

IIG. 16. Cireek scarab of the Gh century 13.C. of the finent atchaic style, teprenenting a salye dancing with a wine-cup in his hand; skilfully designed so as to fill the whole field: one and a half tumes the rad sizi.

style, dating from about the middle of the Gth century lice. This is a large scarab of strifat chaledony in the British Arthat Muscum, No. 289 , representing a bearded Satyr dancing, with a wine-cup in his hand, within a "cable" border. The figure is bent to bring it within the oval field of the scarab: at his feet is a large amphora. The design of this gem is a good example of the pains taken by the Greek engravers to occupy very fully the whole ficld. The workmanship, in spite of its archaic stiffness, is very spirited and sharp in treatment. The use of a large drill for the body of the amphora, and of minute drills for the hair is plainly visible. The tail of the Satyr is put in with delicate strokes of the diamond point'.

Plate 1. no. 5 (described in the appendix) illustrates a fine scarabacoid in the Fitzwilliam collection, cut in rock crystal, with a rigure of a nude hero fitting on his greaves, Coystal dating about 500 I.C.

One of the finest gems which has ever been discoserel, dating from about 460 l.c., is now in a private collection in Scotland; see fig. 17 . The design is a mude figure of

1 Thi, Satyr has previously been pulvinher aw a recumbent higure, but there

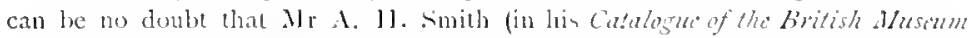
Goms, No. $28 \%$, proge 63 and 1\%. E) has given it rightly in an upright position. 
Sarab of fine'st style.

Style of aiork.

Shallow sinking.

a youth with a bow; he holds in his right hand an arrow, and tries the sharpness of its point with the other

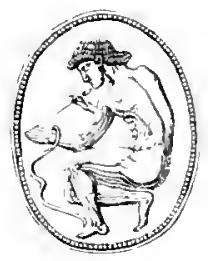

Fri. 17. Greek scaral-gem of the beet perind of ant, and of the fincul workmanship: ane and a half times the real sisce.

hand. He wears long hair, tied up behind his head like the marble statues of athletes, which have recently been found on the Athenian Acropolis among the débris caused by the l'ersian sack of Athens. The general design of the figure and the modelling of the nude flesh are magnificent in style, combining truth to nature with nobility of treatment in a way that could hardly be surpassed even in work on a much larger scale. As an example of largeness of style combined with extreme minuteness and accuracy of detail, nothing could surpass this wonderful scarab.

In both the last-mentioned gems the relief, as is usual in work of this period, is rather shallow, but treated in the most skilful way, with admirable spirit and delicacy of touch. This shallowness or, more correctly; flatness of relief (French méplat) is one of the characteristics of early Greck intaglio and relicf work of the best period. The figure is not treated like a statue sain in half and then applied to a background, but, like the best Florentine reliefs of the 15 th century, is modelled with a peculiar delicacy of surface, and more relief than actually exists is, as it were, suggested. In some cases the edges of the design are, what is called "stilted," that is to say the intaglio or relief outline is bounded by a flat rim at right angles to the ground, as if the whole figure had been slightly pushed out from behind, so that the depth of sinking at the outline is nearly as deep as in the central part of the figure. 
This delicacy of treatment is to be olserved in sem fints. no. 10, as well as in no. 5 of the Fitzwilliam Cataloguce.

Gems of the 5 th century B.C., the fincest period of Greek art, are very scarce in comparison with those both of carlicr and later times. Work as fine as that on the most beautiful Greck coins is extremely rare on gems of contemporary worlimanship.

In the British Museum collection which, though not the largest, is on the whole the finest in the world, from its widely representative character, the number of gems of this period is comparatively small. Among the most notable are thesc110. $4 \sigma_{4}$, a very beautiful and noble bearled head of Zeus ${ }^{1}$, cut on a scarab of green jasfor within a 'cable' border-a work of the finest style with a slight trace of archaic stiffness or rather dignity. No. 555, cut on the section of a sard cylinder, has a seated figure of a man draped below the waist, playing on a lyre of triangular shape.

The general design and motive of this gem are very beautiful, but the nude part of the figure is badly modelled and the general proportions defective.

A more skilfully drawn design is on a fragment of a very brilliant sard (No. 556), with a female draped figure scated in a chair reading froin a scroll, possibly a representation of the poctess Sappho. In front of her, on a pedestal is a lyre: the word EP $\Omega C$ is lightly scratched on the pedestal. The lower part of the gem is missing. This is a work of extraordinary grace and refinement of detail; it appears not to be later than about foo B.C.; the very faintly scratehed inscription must be a later addition, judging from the rounded forms of the $\in$ and the $C(\Sigma)$ and its slight, careless execution." $^{2}$

Another gem of rery sreat beauty, which seems to date from the middle or latter part of the $5^{\text {th }}$ century lic., is

1 This gem in illustrated in figr. 25 at frage 11 .

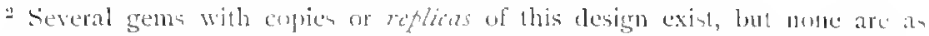

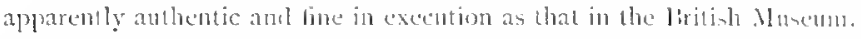

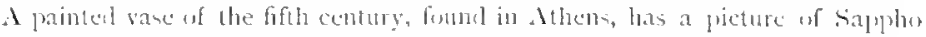
reating one of her own proms from a sewhl, sery timilar in devign wh the gem. 
Lion and a scarabacoid of reck crystal (No. 125), with a lion devouring stag.

$-1 s^{2}$ of

Pritidias.

Plate 1 .

Attic

stilat.

Sipulitiral subject: Pluti 1 . a stag, within a 'cable' border; a work of remarkable delicacy of execution: sec fig. 18 on page 30.

No. 557 , a fragmentary gem cut in chalcelony, has a figurc of a wounded contaur, which, as Mr A. S. Murray has pointed out, is of special interest from its resemblance to the centaurs on the metopes of the Parthenon, and probably dates from about the same time.

On all these very beatiful gems the use of the diamondpoint rather than the drill is clearly visible; see page I I.

Among the few gems which can be attributed to the age of lheidias and his pupils some are slight and even ahmost rude in execution.

Careful work by a really skilful artist on a gem of this time is rarely to be seen, but when it does occur it is an object of very great delicacy and dignified beauty.

The Fitzwilliam collection possesses a very noble example of this class (No. IO), which is of special interest from its design being sinilar to that of some of the finest Athenian sepulchral siclac, of which so many (though in most cases of rather later datc) lave been found in the cemctery outside the Dipylon Gate in the outer Cerameicus The subject on this gem, a large scarabacoid of clouded chalcedony, is a nude figure of a youth, leaning on his staff and caressing his dog-the dog and horse, man's most faithful animal companions, being of frequent occurrence on the sepulchral reliefs of the $5^{\text {th }}$ and $4^{\text {th }}$ centuries I.C. In style this gem is of the noblest type, with a slight trace of archaic flatness of exceution, but with the most skilful modelling of the nude form, and remarliable grace in the whole design and pose of the figure.

Another gem in the Fitzwilliam collection (sec No. I I) of rather later date, with the signature of its engraver, Diamonos. is also engraved with a subject which occurs very often on the Athenian scpulchral stclet, namcly, a lady seated, with an attendant girl assisting to complete her mistress' toilet, very like the beautiful sepulchral relief of Hegeso from the Dipylon cometery. This very important gem is described in the Cata- 
loguc below, where other examples of gems signed by the same artist are mentioned; see page viii.

Some of the most beautiful gems of this period, 5 th and 4th century B.C., were produced by the engravers of Sicily and Nagna Graccia, where it appears to have becn common for the same artist to be an engraver of rems and also of coin-dies. In style many of the fincst coins of these districts show clearly the touch and minute execution of detail which come naturally to a man who is accustomed to work in a harder material than either bronze or iron: as, for cxample, that wonderful tetradrachm of Syracuse with, on the rewerse, a quadriga and above it a flying Victory holding a small tablet or fincer, on which is cngraved in microscopic letters the artist's name, Euainctos, EYAINETO.

The same gem-like treatment is visible on the obverse of another Syracusan tetradrachm with an almost full face of Athene, on whose helmet is cut, in the most inconspicuous way, the signature Eucleidas, EYKAEI $\triangle A \Sigma$.

One of the peculiarities of this most beautiful class of coins is the frequency with which they bear the name of their artist: see the list given by B. V. IIead, Historia Numornm, ISS7, 1). 785 ; and also a valuable monograph by A. J. Evans, "Horsemen" of Turentum, is89. A more recent paper by Mr Evans is mentioned below, see page 90. A good monograple on the signed coins of Sicily is that by

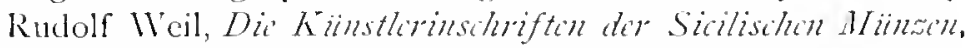
Berlin, ISS4. The subject of signatures on gems and coins is further discussed in Chapter VII.

A good many fine gems exist which reproduce varjous coin-types of Magna Graccia and Sicily, as, for cxample, the (") $g^{*} m \mathrm{~s}$. already mentioned gem, No. 125, in the British Museum, with a lion devouring a stag; see fig. I 8 . This design occurs on silver didrachms of Velia, in Lucania, with the signature (more or less contracted) of the die-engraver $\Phi I N I \Sigma T I \Omega N$ or,

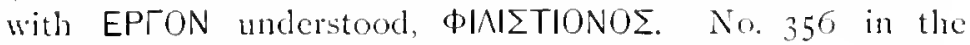
same collection, with IEracles and the Nemean lion, reproduces a coin-reverse of Iferaklaea, also in Lucania; and No. 443 has the man-headed bull crowned by a Victory,

Engraats of cilits and sims.

signent coins.

Gim-like coins. 
which occurs on the well-known didrachms of Neapolis (the modern Naples. The same connection between gems and

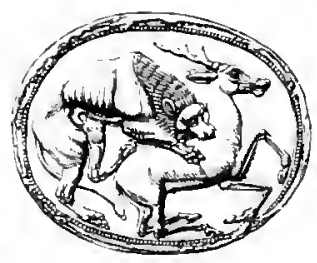

FIs. 1s. Very fine work of the ath century H.C.: one and a half the's the mal size. Cf. the description of gem No. $\rightarrow$ in the Fitsailliam Catalogut.

Copits of coins.

Gims olizats of linumy.

Coins of Sicily. coins is illustrated by a paste camco in the British Muscum, No. 646, which, as Mr. A. H. Snith points out in his catalogue, p. 97, is moulded from a tetradrachm of Syracuse with the front face of Athene; see Brit. Mlts. Cat. of Coins of Syracuse, No. I99: this is the coin mentioned above as having the signature of the die-engraver Eukleidas.

The usual superiority of the coins, as compared with the gems of Greece proper, during the best period of Greek art, may possibly be due to the fact that the coins were intended for public use, while the gems were objects of private luxury. So in the case of architecture, painting and sculpture, we find that all the chief efforts of the greatest artists were devoted, during the great period of Athenian supremacy, to the service of the State, not of private individuals.

In Nagna Graccia and Sicily, on the other hand, personal pomp and luxury were developed at an earlier time; and this may explain the frequently superior quality of the gems of those countries.

It should also be observed that the art-development of the Sicilian and Italian colonics was many years in advance of that in the mother country. The magnificent Syracusan decadrachms of Kimon and Euainctos, exccuted scveral years before the close of the 5th century li.c., are in style quite as adrancel as the work of the artists of Attica fully half a century later. 
The soft beauty and richly decorative treatment of the noble heads of Persephone and Arethusa on the obrerses of these coins, and the almost pealistic treatment of the victorious quadriga on the reacrse, do not at all accord with the usual notions of Greck art before 400 B.C.

A very magnificent kind of signet was also much uscel in Magna Graecia during the fth century bir.-a massive ring with a large flat bezel, all of sold, engraved like a gem with designs of great beauty.

A splendid example in the British Muscum has, cngraved in the gold, a copy of the quadriga on the silver decadrachms of Syracuse. Lxamples of these gold signets signed with the artist's name are mentioned below, see page 73 .

The gem-room of the British Muscum also contains two extremely beatiful cograved signet-rings of gold, from tombs in .Iagna Graccia (Castellani Collection).

Onc of thesc has a bezcl of pointed oval form, on which is cut a very beautiful female head of about 400 I.C. Another has a figure of a youth on horseback, riding at full specd, a marvel of spirited design and minute workmanship, cut with as much sharpness of touch as if the matcrial had been a hard stonc instead of soft, pure gold.

According to Pliny (Hist. Nat. Xxiri. 23) the use of signet-rings made wholly of gold originated in Samothrace. He says that they were not uncommon amoner the Romans of his own time, but his statcment that they were first used in the reign of Claudius is obviously incorrect. In fact rings wholly of gold are among the carliest known examples of signets; as, for example, the ring of "Chcops (Chufu)," who built the sreat pyramid, dating about 3730 I.C., and those found in the tombs of Myccnac, described at pasc 17.

The lists cut every five years on marble stelae, ats inventorics of the sacred treasure of Athene, which was preserved in the Parthenon at Athens, girc some interesting cxamples of gifts of gems, rings and other jewellery about the time of the Peloponnesian war.

The wife of an Athenian called Kimon and a lady named Dexilla dedicated many articles of jewellery; among them 
were various gold and plated rings set with onjer, jasfor and

I'otiz't sifts.

Gims and ringss.

Ioliz't gem.

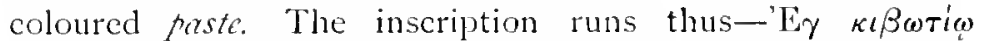

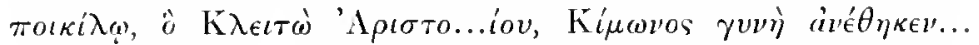

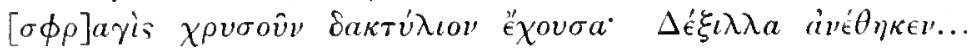
$\sigma \phi \rho a \gamma i \delta \in$ va[

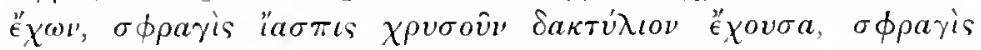

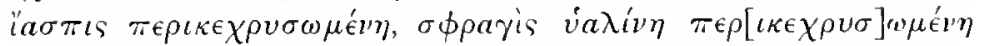

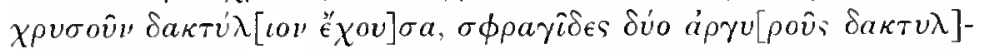

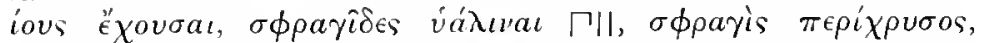

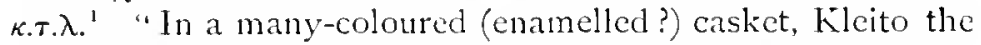
daughter of Aristo..., the wife of Kimon dedicated (the following)...A seal-ring of gold,... Dexilla dedicated...two signets with paste gems of various colours [probably imitations of ony $\mathrm{x}$ ], an engraved onyx set in a gold ring, an engraved jasper in a gold ring, an engraved jasper set in gold [or set in metal plated with gold], an engraved gem made of paste set in gold and mounted in a gold ring, two signets in silver rings [probably the device was cut on a silver bezcl], seven engraved gems of paste, a signet plated with gold, \&c."

In similar lists of other years the following gems and

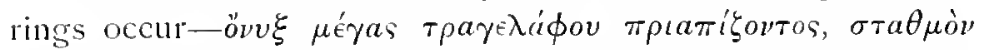
$\Delta \Delta \Delta r+$, "a large ony x engraved with an ithyphallic antelope, wcighing 32 drachms," its great weight suggests that it was

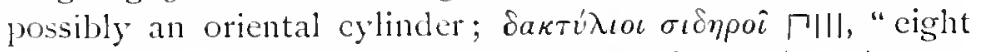

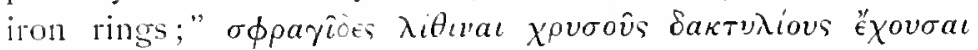
$\Gamma \mid l, a u \in v \delta a \kappa \tau v \lambda i \omega v$ " , "seven signets of stone in gold rings,

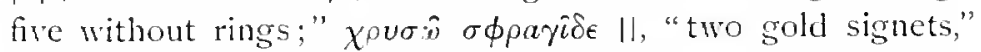
meaning rings in which both hoop and bezel were of gold. In the Parthenon inventories the word $\sigma \phi \rho a y i s$ is used for an encraved gem, the plain jewel bcing called $\lambda_{i} \theta \sigma_{s}{ }^{2}$, or else mentioned simply as "a jasper," "an onyx."

In the Greek Anthologia (1. 205) we read of the Sorceress Nico's gem being dedicated in the temple of Aphrodite. It is described as an amethyst ( $\dot{\xi} \xi i \mu \epsilon v^{\prime} \sigma \tau o v \quad \gamma \lambda v \pi \tau i \eta$ ) strung on a cord made of purple wool, and set in a golden stand. The

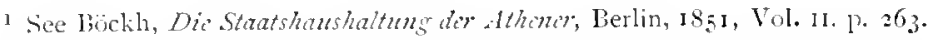

- In Cireek of the best literary periul the feminine $\dot{\eta} \lambda i \theta$ os seems frequently: a poetic form: in later times it wa more uniformly used to denote a fritous stone. 
device on it was the magic wheel, ivy $\xi^{1}$. It was probably a large scarabaeoid or perhaps even an Oricntal engrared cylinder.

In later times, from the reign of Alexander downwards, large collections of engraved gems ( $\delta a \kappa \tau v \lambda \iota 0, \hat{j} \kappa a t)$ were made Collutions of sims $^{2}$. by wealthy Grecks, such as Attalus II. King of l'ergamus, I 59- I 38 F.C., and cnormous prices were sometimes paid for the work of a eclebrated engraver.

The wearing of costly sems secms to have been rery common in certain Hellenic districts. Aelian (Tor. Thist. XII. c. 30) tells us that in the Greek colony of Cyrenc in Northern Africa, even the poorest person wore a gem of the value of Io minae (about $£ .40$ to $£ 50$ ) and that "the gemcngravers there were a marvel," though whether for their number or their skill he does not explain.

The writer of the Apocryphal Fook of Ecclesiosticus (xxxiii. 27) who was probably a Jew of Palestine, mentions, among the craftsmen without whom "cannot a city be inhabited," the makers of signets-"they that cut and grave seals, and are diligent to make great variety," an interesting testimony to the importance of this branch of $\mathrm{art}^{2}$.

In some cases large numbers of rings were worn by ladies of rank. For example when the tomb of a Queen of the Chersonesus, at Nicopol in the Crimea, was opened, no less lings from Niofol. than ten rings were found upon the fingers of the sheletonall of them fine Greek work of the th $^{\text {th }}$ century 1.C.; sec Comp. Rend. Comm. Aril. I 864, p. I 82, and Pl. v.

The recumbent figure on an Etruscan terra-cotta sarcophagus in the Lourre has four rings on one hand, two of them with very small hoops only reaching to the first joint of

\footnotetext{
I One form of the org was a wheel on which a bird of the wryncek tribe was fastened. If spun in one direction it inspired love, but revolved in the other direction it caused hatred to be developed in the heart of the victim of the

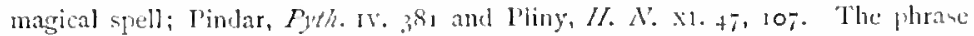

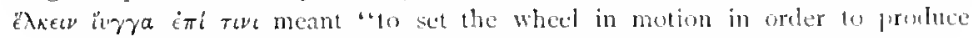
the mayical effect upon some one"; see Xenoph. .Kem. III. I r, 17.

2 The high estimation of Greck gem during the later periul of art is lurne witness to by the number of epigrams on engraved gems which occur anong the collection of poems in the Givels Antivelogit.
}

II. 
the fingers. This explains the very smatl size of some ancient rings both of Greck and Roman workmanship.

With regard to the names used for the various parts of a signet-ring, it may be noted that, owing to the manner in which the gold wire of a swivel ring frequently encloses and Funda. frames its scarab, the name $\sigma \phi e v \delta o \nu \eta$, Latin fund w, was given to that part of the ring which borders the gem, on account of its resemblance to the stone in a sling: see Eur. Hiffol. 876, and Pliny, Hist. Nat. xxxvin, I 6 and I 26.

The gem itself is $\psi \hat{\eta} \phi o s, \delta a \kappa r v \lambda \epsilon \kappa \dot{\gamma} \psi \hat{\eta} \phi о s, \sigma \phi \rho a \gamma i s$ or $i$ $\lambda i \theta o s ;$ in Latin, gemmo. In modern English the part of the ring which bears the device, whether on metal or on a stone, bis\% is called the bead: the rest of the ring being the hoop, and its thickened part near the bezel the shouldors.

Chaton. In French the chaton is the whole bezcl, while the word collet is popularly, but not technically, used for the funda or metal border which frames the gem.

With regard to the Greek use of signets, Professor Jebb has kindly pointed out to me and explained the following interesting passage in Isocrates, Or. XVII, $\$ 33,34$, where two different classes of sealing appear to be referred to.

lotin The Voting-uns (idpial), containing the names of the ums semlet. Athenians who were eligible for the office of Judge in the dramatic contests at the city Dionysia, were placed under the

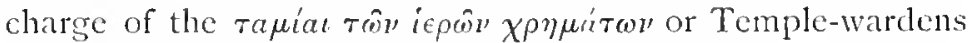
for safe kecping on the Acropolis of Athens, most probably in the treasure-chamber of the Parthenon.

For the sake of security each urn was sealed both by the

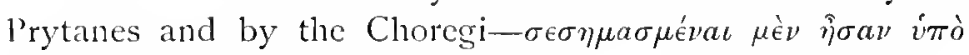

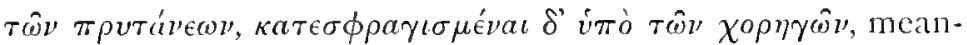
ing, Professor Jebb suggests, that the urns were not only scaled up by the Prytanes, perhaps with a sort of corporate countr. or common seal, but were also counturealed by each of the sinl. Choregi with his own private signet ( $\sigma \phi \rho a \gamma i s)$.

In a similar way, during mediaeval times, it was usual for an official, such as a bishop or an abbot, to sign important documents with his great seal of office and also with his scowtum or personal signet. 


\section{CIIAPTER III.}

\section{Later Greek Geas and Etruscan Scarats.}

Tilougu the Greeks highly appreciated the beauty of engraved gems, and, at least from the time of Alexander, gave large prices for the works of celcbrated engravers, yet it was among the Romans of the 1 mperial period that the passion for collecting ancient gems, like that of buying other costly works of art, rose to the highest pitch of extravagance.

Many of the wealthy Romans formed cabincts of engraved grems, containing cxamples both of antique and contemporary workmanship, but in either case the gems which were thought worthy of the dactyliothea were probably the work of Greel: not Roman artists.

Pliny (Hist. Nat. xxxvil. 4) mentions the dedication by" the Emperor Augustus in the Temple of Concord in the Roman Forum of a gold horn containing a sardonyx, popularly supposed to be the original gem which Polycrates Tyrant of Samos, in vain threw into the sea to appease his Nemesis: older records however tell us that this celcbrated stone, engraved by Theodorus of Samos, was an encrald; sec Herod. 111. 39 scq.

Moreover the gem of Theodorus was engraved with a device, which according to Clemens Alexandrinus was a lyre -the ring being the royal signet of Polycrates and therefore necessarily having an engraved device; while Pliny tells us (HI. N. xxxvil. 8) that the sardonye of Augustus was plain"intacta inlibataque est." The Temple of Concord contained

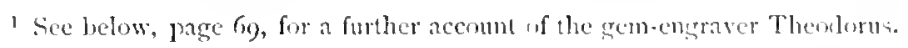


an important collection of gems, among which the so-called "ring of Polycrates" made, Pliny tells us, but a poor figure.

Gims of Srawrus.

Gitms of Pompiy.

Catrar's se'ms.

Gims in the Tomple of Afollo.

Sials used as locks.

The earliest gem collector, Pliny says (Hist. Nat. xxxirit. 11), was MI. Aemilius Scaurus, the stepson of Sulla; a man of enormous wealth, whose temporary theatre, built during his acdileship in 58 B.C., was one of the costliest and largest buildings in Rome'.

The next collection of Greek gems in Rome was that which had belonged to Mithradates, and was dedicated in the Temple of Capitoline Jupiter by Pompey the Great, whose victory and its consequent spoils created, Pliny says, the taste for gem-collecting in Rome (Hist. Nat. Xxxill. 12)".

Pliny mentions that Julius Caesar gave a collection of ring gems (dactyliotheca) to the Temple of Venus Genitrix, which he built in the centre of his new Forum Julium. Suetonius also tells us ( $\mathcal{F}$. Cacs. 47) that Julius Caesar was always ready to give high prices for gems which were the work of any of the famous old Greck engravers.

Marcellus, the favourite nephew of Augustus, dedicated another collection of gems in the Temple of Apollo on the Palatine Hill-the most magnificent of the many public buildings with which Augustus enriched the city of Rome; see Pliny, Hist. Nat. xxxvir. i I.

It was not, however, till comparatively late times that engraved gems were regarded as objects to place in a collection of works of art or even to set in jewellery as personal ornaments. Their real use was for long the purely practical one, that of signets, either to give authority to a document, or else, instead of a lock, to secure doors, box-lids and the like, so that they could not be opened without the knowledge of the owner who had affixed his seal; see page 34 .

Aristophanes (Thesmo. 424-428) has an amusing passage referring to the custom of securing doors with a seal-

] The splendours of the Thentre of Scaurus are described ly l'liny in many

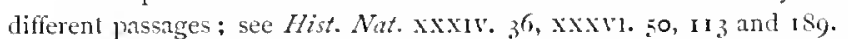

2 In the same way, according to Pliny (loc. cit.) the rage for pictures was the result of the capture of Corinth by L. Mummius $(1+6$ IB.c.), and the laste for other luxuries, such as embosed silver plate, cloth of gold and bronze conches, was lronght abut hy the compuests of L. Scipio and Cn. Manlius. 


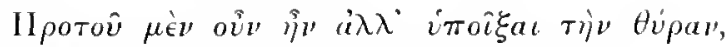

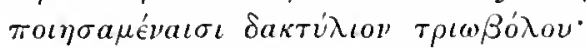

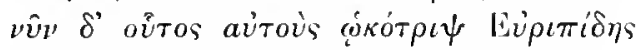

Aristopht.

\%osme. $+2+-2 s$.

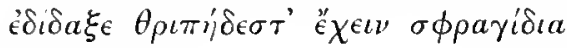

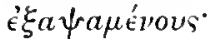

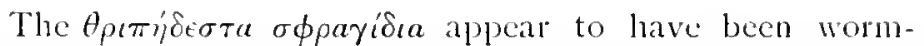
eaten bits of wood used as rude seals, because no two would Itiol sats. be exactly alike and the pattern made by the worms was too complicated to allow of imitation.

An analogous contrivance was adopted by some of the early Ottoman Sultans of Turkey, who both signed and sealed their edicts by the single act of pressing the inked paln of the hand on the document, so that the lines of the skin printed off on the parchment or paper, forming a device which no forger could possibly copy. The elaborate device on modern Turkish coins is derived from the old handprinted signature of the mediaeval Sultans, though it has since been partly modified into a sort of complicated monogram of the Sultan's name.

Votive offerings dedicated in temples were in some cases scaled with an impression of a signet in clay. During $\mathrm{Mr}$ Flinders letrie's recent excarations in Upper Egypt examples of this were discovered; as, e.g. a bronze votive adze tied round with thread, the knot of which was sealed with a clay impression of a scarab.

The scarabs of ligypt and the signet-gems of the Grceks and Romans were also commonly employed to seal the plaster stoppers of amphorae full of wine. Many examples of these with the seal unbroken have been found in the Delta and elscwhere in Egypt.

With regard to the use of signets in the wine-cellar, Horace mentions as the test of a good-tempered housemaster-"Signo fracto non insanire lagenac," that he did not go wild with passion even if he found that the seal of a winejar had been broken. I'liny, in his treatise on finger-rings (Hist. Nat. XX.xili. 26), refers to the same custom when he says "nunc cibi quogue ac potus amulo vindicantur a rapina" 
II (i) $\%$ (1) $24, y$ shonts.

Siarals form.

Thinnty form of stin.

Conetex sic $\left.{ }^{\prime}\right) s$.

This practical use as signets explains why in so many cases among ancient Greek gems very beautiful work is engraved upon an ugly stone, the markings of which interfere with and obscure the design. The main object was that the impression from the gem, rather than the stone itself, should be beautiful. This is notably the case with the celcbrated head of Medusa from the Strozzi collection, now in the British Muscum, which is cut on a very opaque and much mottlcd chalcedony, - a fact which is evidence in favour of the antiquity of this beautiful $\mathrm{gem}$, in spite of its style, which certainly suggests the hand of an artist of the Renaissance, rather than one of any classical period.

As has been already mentioncd, until about the midule of the th $^{\text {th }}$ century B.C. Greek gems were usually cut in the scarab or scarabaeoid form; the latter were frequently of large size, especially when made of chalcedony; in which case the old method of wearing the signct strung on a cord round the neck still survived. After that, from the time of Alexander downwards, the custom came in of having gems engraved on a thinner slice of stone; and the brilliant varieties of sard or carnelian became the favourite gem to work upon. For the sard the thinner body of stone was an advantage, making it more transparent and effective, whereas the older scarabaeoid shape was best suited for the pale bluish or milky ehaccdony, which looks poor if cut very thin. This rule is not without many exceptions; thin sard gems occur of date much anterior to Alexander's time, and the use of chalcedony was never given up either by Greek or Roman gem-engravers.

Another common variety of shape, used mainly by the Romans, was to have the side of the gem, on which the design was cut, convex; the plain back being flat. This form is very common among Roman gems of Imperial times, and it was often used for stones the colour of which requires an cxtra thickness of body to bring out the full richness of tint, a.s in the case of carbuncles and reddish sards. A less common shape, largely used for mediaeval and modern gems, was the reverse of the last, namely a convex back, with a flat 
face. Either of these forms is especially suited to the carbuncle, which looks glassy and poor in colour if not convex on one side'.

The modern name for this rounded form is cn calvikon: it is now only used for a few stones, such as opal, turquoise and carbuncle; transparent gems being almost always cut with many facets.

The cabechon shape was used for all gems throughout the middle ages, and it was not till the Ioth century that the faceted form was much uscd. In many cases the old rounded form gives much greater beauty to a gem, especially to one in which the chief beauty is colour rather than brilliance or "firc." The diamond, on the other hand, if not cut in facets, has little more beauty and effect than rock crystal.

Stones, such as the amethyst and the garnet, which often look poor and tawdry when faceted, have great decorative beauty when cut in the older fashion, and the modern sy'stem is applied, with great want of taste on the part of jewellers, to many stones which are quite spoilt by it.

Another advantage of the old system of cutting is that flaws, which are destructive of the beauty of a faceted gem, in many cases do little, if any, injury to a stone cut in the cabochon form.

In Oriental countrics the old method of shaping gems still survives, and modern Indian jewellery of very great beauty and decorative effect is often made with gems, which, in the hands of a European jewcller, would be almost valueless.

The only antique cxamples of faceting were those gems in which the natural crystalline form was prescrved, namely the diamond which was too hard to cut, and the beryl which in some cases had its matural hexagonal crystals polished; I'liny, $H . N$. xxxvit. 76 . The emerald also was often used in its natural crystalline form.

1 'Carbuncle' and 'garnet' are different names for the same gem accorling to the shape in which they are cul-the "carluncle" leing the stone t"n caliothon, and the "game" cul with facets. "Calochon" is derived from the I'ortuguese "cabo," a head. 
With regard to the prices paid by the Greeks for fine gems, we have little or no information.

Emorald hought by Isminits.

Teriod of Alatander.

Grivio. hionan sims.

Portraits on sims.
Pliny (Hist. Nat. xxxrll. 6) tells a story of how the fluteplayer Ismenias', who lived in the time of Alexander the Great, sent six gold staters to buy an emerald engraved with a figure of the sea-nymph Amymone, and was disgusted to have two staters returned to him with the gem, on the ground that an insult had been offered to the emerald through its price being beaten down. In this case however, as Mr King remarks (Handbook of $G_{e} \cdot m s$, p. 196), the stone itself may have been worth the greater part of the money, so that we have no indication of what the value of the work on it may have been.

According to Pliny, Greek musicians were specially given to the cxtravagance of collectiner and wearing many gems.

During the Alexandrine period and later the character of Greek gems, like that of other works of art, changes very much; the type of figure becomes softer and more feminine in bcauty, Homeric scencs are no longer represented, and deitics such as Aphrodite or Dionysus, with subjects relating to the theatre or musical contests, become the favourite motives for representation.

Greek gems of this later period and good Graeco-Roman work of the time of the early Roman Empire are usually almost indistinguishable, either in workmanship or in subject. This is frequently the case even with large sculpture in marble ${ }^{2}$, and with work so minute as that of the gem-engraver it is harder still to arrive at any certainty.

With the time of Alexander portraits appear for the first time on gems: a little carlier, that is, than the introduction of coin-portraits, which commence with the Diadochi, Selcucus I. King of Syria, and I'tolemy I. of Egypt. Lysimachus

1 Immenias was the author of a work on precions stones.

a A striking example of this is to te scen in the reliefs on the throne of the 1ligh Priest of Dionysus in the great theatre of Athens. The figures of Eros with fighting cocks on the arms of the throme and the two Fauns on the back look like the hest Greek work of the $4^{\text {th }}$ century B.C., and it is only the feeble archaism of the pseulo-Assyian relicf on the front of the seat which betrays the later origin of the whole. 
of Thrace used on his coins, instead of his own portrait, a magnificent head of the deified Alexander, an idealized portrait of the noblest type.

Though Alexander nerer committed the injpiety of phacings his own head in the place of that of a deity on his coins, he employed the celebrated Pyrgoteles to engrave it upon gems -using for that purpose an emerald, according to l'liny, Hist. Wat. xixvil. 8 ; see below, page 7 .

The British Museum possesses two very fine portraitgems (Nos. I526 and I 529) copied respectively from tetradrachms of Demetrius l'oliorcetes and of a king of l'ergamus. Figr. ig shows the latter, probably a portrait of Eumenes 1., $263-2+$ I B.C.

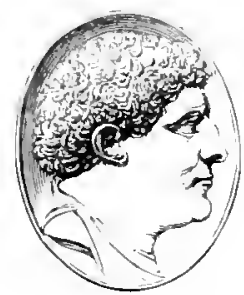

Fig. I9. Very noble example of a Givele portrait gem of the zrol century s.c., cur un molted chalcetony, very similar in style to the finesl silver tel radrachmo of lergamus; real sizi:

No. 1530 in the same collection is a copy in paste of the coin-portrait on tetradrachms of the great Mithradates, c. 90 I.C.; which, again, seems to have been taken from a large group of sculpture in bronze, probably a quadriga driven by Mithradates; hence the eager expression of the face and the hair blown back by the wind.

In Roman Imperial times portraits were very frequently cut on gems, especially that of the reigning Emperor, which was commonly worn by his courtiers as a compliment to him.

l'ortrait heads of Greek philosophers were also very largely. worn by the Romans in their rings: Cicero (Di Fin. V. I)

Coin portiait.

Iontraits of the Empiror.

Philosophers. ridicules the Epicureans for their habit of using their master's head as a signet. J Jeads of Socrates are specially common on gems; see No. 65 in the fitzwilliam catalogue. 
Commiens' rimss.

Afollo of Kanactios.

Hars and linus.

Lanoon swonf.

P'liny (Hist. Nat. xxxirl. 41) tells us that a portrait of Clauclius in a gold ring was worn as a sort of entrance ticket by those privileged persons who had the right of access to the Imperial presence.

The later Greek and Graeco-Roman gems are in many cases of exceptional value and interest from the fact that their device represents some important work of Greek sculpturc-in some cases one which can be identified by descriptions as being some celcbrated, but now lost statue or group. Thus, for cxample, a gem in the British Museum (No. 720) appears to be copied from the famous bronze statue of Apollo holding a stag by its fore-legs at Branchidae by the sculptor Kanachos of Sicyon, who worked in the early part of the 5th century B.C.; see Proceet. Soc. Ant. and series, Vol. xi. p. $253^{1}$.

Another gem (Brit. Mus. No. 722) has a representation of the Apollo Sauroctonos of Praxiteles, of which several ancient copies exist both in bronze and marble; and No. 790, a badly cut gem of late Roman date, is interesting for its group of Aphrodite and Ares with Eros at their feet-a noble Greek design of probably the 3 rd century B.C., of which more than one Roman copy in marble still exists".

Valuable evidence with regard to an important work of art is given by the impression in wax from an ancient gem, which was used as the private signet of Thomas Colyns, Prior of Tywardreth in Cornwall from 1507 to 1539 . A document still exists sealed by the Prior with his signet-gem on which was engraved a copy of the celebrated Laocoon group, now in the Vatican.

The true position of the lost arms of Laocoon himself and one of the sons is shown on this seal; though the group itself has been restored differently, in a way which very much

1 The finest extant representation of this celebrated statue is on an engraved paste gem in the collection of Mr A. J. Erans at Oxford.

"This is the motive of the group to which the Aphrodite of Mlelos is supposed hy some writers to have belongerl. The Capitoline Museum possesses a ralher luticrous copy, in which the heats of Ares and Aptrodite are replaced ly those of IJalrian and his wife Sabina. 
injures the general lines of the composition'; see $1 \mathrm{r} / \mathrm{h}$. F mm xirs. p. 45. It is, of course, possible that l'rior Colyns' signet was copied from the then recently discovered Laocoon group during the early part of the isth century, but on the whole it appears more probable that it was an antique gen.

A great many other instances might be guoted of antique gems which are of value for their record of important works of Greek art, now lost.

The same sort of cridence is frequently given by the reirse types of coins; but unfortunately the greater number of coins which illustrate ancient sculpture belong to a late period of dccadence, and are too coarscly cxccuted to give an accurate notion of the statues they represent; a lirge number of examples are given in a valuable work by Professur Gardner and Dr Imhoof-Blumer, Numismatic Commotary on Pausanias: first published in the Foumal of Hollonic Studies, I 885 to I 887 .

The importance of antique gems as giving us the designs of lost statues is eloquently pointed out by l'rofessor StoryMaskelyne in his preface to the Catalogute of the Marlborought Gems, I 870 , p. xxiv._- "if we could but assemble in one collection the still extant gem-signets of the different ages and families of man from the days of Urukh to those of the latest Sasanian lings, we should have a more complete representation of the objects that stirred the minds and ruled the hearts of men through all those many ages and changes of circumstance, than would be afforded by any other single form of their arts--indeed we may perhaps with justice say, than by all the other forms of these that remain to us combined."

It should, however, be observed that gems which bear designs copied from important works of sculpture are in most cases productions of the Roman Imperial period, when the decay of good taste and judgment allowed designs to be cut on gems which were quite unsuited for such a purpose.

The reasons for this unsuitability are obvious; in the first

1 The carefully devised pyramidical scheme of composition in the laocum group is spoitt by the position of the restored arms, which straggle, as it were, untside the proper lounding line of the composition.

Importwitis' of $g_{c} \cdot m s$.
Lentow ¿roup.

Silaters all ioins. . 
Requisites place a design of ligh merit must be specially suited to the

of $a$ sem ilesisn. scarabs.

Foritisn imports.

Siavals useid as ornuments. scale on which it is meant to be executed, and therefore no design could be greatly enlarged or diminished without a serious loss of beauty and fitness.

Again, a grem design, being a variety of bas-relief, should be most strictly kept to one plane, quite unlike the natural composition of a piece of sculpture in the round; and, last of all, in copying a statue it was ustally impossible to make the design occupy the field of the gem in that complete way which was thought so desirable by the engravers during the best period of Greek art.

\section{Glis FROM ETRUSCAN TOMns.}

This is a very large class and embraces gems of many different kinds, extending over a long period, but the greater number fall between the 6th and the zrd century isc.

Among the earlier gems a large number are foreign imports, either of Phoenician or Greek workmanship. The demand for engraved gems, mostly in the form of sard or carnelian scarabs, must have been very great among the wealthy and luxurious people of Etruria, whose gold jewellery is of cxtraordinary beaty and magnificence.

These engraved scarabs were not used by the Etruscans merely as signets, but were also employed in large numbers as personal ornaments.

Almost all have some form of the "cable" border, and the majority are cut in the scarab shape, perforated, with the head and wing-cases of the beetle carefully shaped. In some cases the original beetle form has been sliced off ${ }^{7}$, for convenience of setting, occasionally leaving traces of the horizontal perforation, found in all true scarabs.

Many of these sard scarabs from the tombs of Etruria are strung in rows on necliaces, or used as pendants for bracelets and ear-rings, in combination with the most exquisitely delicate gold work.

1 The gem shown in fig. 22, page 10\%, is an example of this form, which is commonly called the "cut scaral,". 
In addition to these imported Phocnician and Greck scarabs, a ccrtain number are cridently the work of the Etruscans themselies, who appear to have becn the most skilful of craftsmen in all the arts, but cndowed, like the Romans, with very littlc power of original design.

Scarabs with Etruscan subjects very rarcly occur; in almost all cascs, not only in style but in subject also, they are copicd from Greek gems; favourite subjects being Homeric scenes, heroes in council or battle, and single figures of legendary Greeks of the heroic age, or occasionally athletes of contcmporary times; sirens, harpies, centaurs and other Greck mythical subjects arc not uncommon.

Not unfrequently these scarabs bear inscriptions in Etruscan characters, most commonly names to explain the subject or person represented, as on the Greek vases of the 6th century $1 \mathrm{C}$. In some cases these names have becn added by the Etruscans on imported gems of Greck workmanship ${ }^{1}$.

No class of $\mathrm{gcm}$ has becn so extensively forged as thesc Etruscan scarabs, especially during the present century, and their manufacture still goes on with much skill in Rome and other places in Italy.

There is an interesting treatisc on these gems by Köhler, Abhandlung übor Käfor-gemmen and Etruskische Kunst, in

Niztion Etrusran scarabs.

Subjeds on scarabs.

linsigit tions.

Kither on scarabs. which Etruscan scarabs are divided into thrce classes.

I. From the 7 th to the middle of the 5 th century 13.C. gems of good stylc engraved on sards and other stones of very fine quality, with heroic subjects, frequently taken from the mythical stories of the Trojan and Thcban wars. On this class inscriptions are common, usually names to explain the person or the scene which is represented.

It. From the middle of the 5 th century to c. 2 So I.C.

I In the same way we see Etruban and Latin inscriptions rudely cut on the beatiful engraved bronze cistize of purely Ilellenic workmanship.

The whole subject of Etruscan art has (more recently) been treaterl in a very

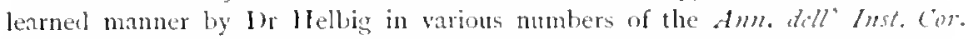

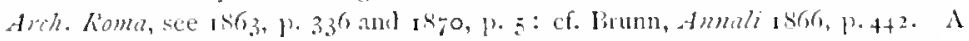
large number of Etruscan scarabs are pulblished in the Bull. Inst. Cor. Arh. 1s.3,

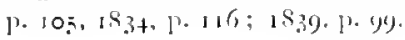


scarabs with similar subjects, cut on less fine stones, and without inscriptions.

Late III. Period of decadence, c. 280 B.C. to the time of Julius samels. Caesar, rudely cut figures, some almost wholly executed with the drill ${ }^{1}$, and cut on stones of poor quality.

This classification is not wholly satisfactory, and Köhler does not sufficiently distinguish between imported gems and those executed by native Etruscan artists.

1 To this class kohhler would assign the drill-cut scaral, shown in fig. 22 , mage $10 \%$ 


\section{CHAPTER IV.}

\section{ROMAN GEMS.}

As is the case with the other arts, the best "Roman gems" are Greek either in design or workmanship, if not in both. The finest gems under the Empire were produced by Greek engravers, in some cases probably slaves or freedmen, or else by Romans who were Greeks by training.

There are however a very large number of gems of inferior style which can be called Roman in a fuller sense of the word. Under the Republic the use of engraved gems by the Romans seems to have been comparatively limited-partly, no doubt, on account of sumptuary laws, written and unwritten, like those which so strictly limited the jus anmuli anei during the carly days of Rome.

A very characteristic example of a Roman gem is that in a signet-ring (formerly in Lord liererley's collection ${ }^{1}$ ) which The ring of Sipio. can be dated about the year 300 I.C. owing to its having been found in the great feperino sarcophagus (now in the Vatican) of Lucius Cornelius Scipio Barbatus who was consul in 298 1.C. This is a gold ring set with a sard on which is cut, in a dry, wiry manner, a standing figure of Victory, winged and holding a palm-branch. The same figure treated in a similar way occurs on a very large number of Roman gems: No. 3 I in the Fitzwilliam collection, engraved on chalcedony, is a good typical example of the design, and of the style of the early Roman gem-engravers generally.

1 This historical ring was inherited, with the rest of Lord Beverley's gems, Iy Mr IIeber I'ercy, and has since heen purchased by the I uke of Northmmbrlanel; it is preserved, with the rest of the l'ercy collection, at Inwicli Castle: 
Ditis on rems.

Ilate II

Greck types.

Lalin ditities.

Portiait sens.

The most frequently recurring subjects on Roman gems of this class are figures of Jupiter enthroned (sec Nos. 26 and 27. Fitzwilliam catalogue) Minerva, Juno and other deities such as the Dioscuri, who were specially worshipped in Rome and are represented on the earliest of the Roman denarii" Another very favourite subject is the gaddess Roma, enthroned-a type which was adapted from certain Greek representations of Athene, as, for cxample, that on the tetradrachms of Lysimachus with the head of the deificd Alexander on the obuerse.

Nost of the Roman deities are represented in forms taken from Greck art-Jupiter, Juno and Minerva, the great triad of carly Latin worship, have the dress and the symbols of Zeus, Hera and Athene: and it only rarcly happens that any deities are represented in a more native and un-Hellenic fashion. One of these exceptional cases of a native Italian deity, who sometimes occurs upon gems and coins of the Republican period ${ }^{2}$, is Juno Sospita with a serpent by her side, wearing a head-dress made of goat's skin-the special cultus-deity of Lanuvium.

Under the Roman cmpire, gems of all kinds, cut on a great varicty of stones, and with every degree of excellence of workmanship, were extremely common.

Apart from the Graeco-Roman gems, which had little or nothing about them that was really Roman, the finest class is on the whole that with portrait heads either of the Emperor or some member of the Imperial family, or else that of the private owner of the $\mathrm{gcm}$; a large number of this latter class must have been engraved for wealthy Romans, judging from the frequent occurrence of well exccuted portraits, which cannot now be identified. Even these portraits of Romans are in many cases evidently the work of Greek artists, as thcir noble and refined treatment clearly shows.

1 No. 3,3, with a standing figure of Minerva, and No. 49, with a hust of Victory, both in the Fitzwillian collection, are good examples of lioman gems of the Republican period; they are illustrated on Plate II.

"For example the head of Juno Sospita or Sispita is a common olderse type on denarii struck by mondariz of the I'ajia and lioscia families. 
One of the finest that now exists is the portrait of Julia, Titus' daughter, by the engraver Eundos; see below, pase 7.1.

Among the recently acquired Carlisle gems in the british Muscum there is a masnificent intaglio on chalcotony with the portrait head of an elderly, close-shaven Roman, with closely cropped hair, somewhat similar in style to the so-called head of Sextus Pompey, signed by Agathopous, in the Florentine collcetion. This wonderful cxample of iconic art, though noble and dignified in style, is treated with much minuteness of detail and rivid realism. Even a pimple on the chin is represented; sugsesting that the sturdy. Roman, whose portrait the gem shows us, had simitar vicws to those held by Oliver Cromwell with regard to the desirability of realistic truth in portraiture. The Carlisle sem, like all the finest Roman portraits, is thoroughly Greek in style, and is probably the work of a Greck cneraver of the first century r.c.

It may however be carlier than that, as the work both in design and execution is quite equal to the finest portrait heads on the coins of the Selencid and Attalid Kings strucli between about 300 and 150 I.C.

In addition to the Roman taste for gems simply as works of art, their old importance as signets still survived. l'liny records (Hist. Nat. XXXYI. ro) that the Emperor Augustus used for his signet the figure of a Sphinx; mainly on account of the accident of his having inherited from his mother two exactly similar gems with this derice. Thus when Augustus was abroad he could intrust the duplicate signet to his fricnels, and so give them authority to issuc any necessary edicts in the Emperor's name. The Sphinx, cut in a very sem-like manner, occurs on the reerse of a silver coin of the cistophoms standard struck in Asia by Augustus; and this coin very probably shows us what his signet-gem was like.

The British Musem possesses a finc gem with the Sphinx device (No. 476 in the Catalogue), which seens to have becn derived from the early coins of Chios. After a time, owing, Pliny says (Hist. Nort. Xxxvir. 10), to jokes made on the Sphinx-like obscurity of Augustus' edicts scaled with the Sphinx signet, the Emperor changed the device of his scal, 
and used instead a head of Alcxander the Great, probably a contemporary portrait by the famous Pyrgoteles.

Suctonius (Aug. 50) says that Augustus used, at different times, three different signets, first the Sphinx, secondly the head of Alcxander, and lastly his own portrait engraved by Dioscorides. This last signet was used after the death of Augustus by subsequent Emperors, down to the time of Pliny's writing his Historia Naturalis, with the one exception of Galba, who preferred to seal with his own signet, on which was cut his family device-a dog standing on the prow of a ship; sce Dio Cass. LI. 3.

Frog Maccenas used as his official scal a gem engraved with a signit. frog, a device which was, as Pliny says, well known and much dreaded on account of its association with edicts for the imposition of taxes.

This device of a frog occurs on more than one of the scarabs which have been found in Etruscan tombs. A gond example is in the British Muscum, No. 474.

Pling $\quad$ A very interesting account of Roman signet-rings ${ }^{1}$ is given on rings. by Pliny (Hist. Nat. xxxill. 8 to 36). He repeats the legend about the earliest ring being that which Prometheus wore after his liberation by Zeus, with a bit of the rock to which he had been chained, set in a ring made of iron from his fetters, thus saving Zeus from perjury, who had sworn that Prometheus should remain for ever bound upon Mt Caucasus; sec Catull. Lxiv. 295--298.

In early times (Pliny thinks) rings were but little worn by the Romans; among the statues of the kings on the Capitoline Hill, those of Numa and Servius Tullius were the only ones which had rings. The right of wearing gold rings anci. was very sparingly granted: at first only to Ambassadors while abroad on state affairs, to whom a gold signet was siren at the public expense; on his return to Rome the Ambassador surrendered his gold signet and again wore the usual iron ring of a Roman citizen.

By degrees the jus anmuli anuei was granted to one official

1 On ancient rings, see the very learned treatise by Kirchmam, Ne Anulis, Sileswick, $165 \%$ 
after another; Senators and Consuls being the first to enjoy. the privilege. It then became the mark of the Equestrian Order ${ }^{-1}$, and finally, under the later Roman Empire, the gold ring became the mark of any man of free birth, a silver ring beings the badge of a frecdman, and an iron ring that of a slave.

Pliny remarks (Hist. Not. XXxill. 23) that in his time the iron rings of slaves were sometimes plated with gold. Platid "ferrum auro cingunt": a form of signet of which a good many examples have been found, owing to the protection against rust which is afforded by the gold: otherwise iron rings have usually perished from oxydization?

With regard to the Roman names for rings, in addition to

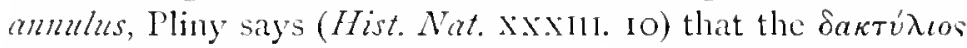
of the Grecks was called in Old Latin ungulus, and in later times symbolum; the latter word $(\sigma \dot{\mu} \mu \beta o \lambda o \nu)$ referring more strictly to the device on the signet: see Plaut. P'seut. Il. ii. 53 and IV. ii. 44. Another carly Latin word was conderlium,

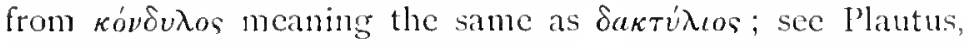
Trimummus, IV. 3, 7, where the word is not used as meaning specially a slave's ring, since it was probably his master's ring that the slave in the Play lost. A Comedy of Plautus entitled Condolium was so named in imitation of Nenander's Drama called $\Delta a \kappa \tau \dot{\lambda} \iota$ сs.

The clay or wax impression from the signet was called sigillum as well as symbolum: e.g. Ciccro (Acad. 11. 26, 85) uses the phrase "sigilla annulo inprimere." The word sigmem is used for the act of sealing, e.s. Ovid, Mitam. 1.. 566 ,

"Protinus impressa signat sua crimina gemma."

Many ancient sold rings, both Greck and Roman, are made thin and hollow, so as to make the most show at the least cost: they are unfortunately very liable to be crushed. This is the lind of ring which the Roman Flamen Dialis

1 IIence the mottuts of gold rings sent to Carthage ly llamilat after the battle of Cannac, in $21^{6}$ f.e., or according to other writers three molii: sece Livy, xxill. 12.

2 The use of iron without any gem for betrothal rings still survived in Pliny's time; Klist. Nith. xxxint. 12. 
$T h c$ Flanten's rins.

Piron rinss.

Thift of solit.

Hearigr solit rimss.

Sulifects on stems.

was obliged to wear, in accordance with the curious and mysterious list of restrictions and duties which are recorded by the celebrated mural painter and historian of Republican Rome, Fabius Pictor (quoted by Aul. Gellius x. 15, \$5). lle says-"Item annulo uti, nisi pervio cassoque, fas non est." These light rings of beaten, not cast gold are mentioned by" Ovid (A. A. 111. 221)--

"Annulus ut fiat primo colliditur aurum."

The cavity in the ring was sometimes filled with poison, so that the wearer could at any moment commit suicide: a method adopted by llamibal (Juv. Sot. x. 164),

"Cannarum vindex et tanti sanguinis ultor Annulus."

In calling the ring "Cannarum vindex" Juvenal is probably alluding to the modius of gold rings, which llannibal collected from the slain equites at Cannac.

Pliny records (Hist. Nat. xxxill. I4 and I5) that the guardian (aedituus) of the Temple of Capitoline Jupiter killed himself with his poison-ring, to avoid being tortured, when the public store of gold, 2000 pounds in weight, was stolen from its secret depository inside the throne of Jupiter. This happened during the third consulship of Cn. Pompeius Magnus, whose colleague M. Licinius Crassus is supposed to have been the robber. See also Hist. Nat. Xxxili. 25, where Demosthenes is said to have killed himself with a similar ring.

In the same passage I'liny says that some people preferred to have a valuable gem set in a light, hollow ring, so that it might be less liable to injury from a chance fall.

Others, whose wcalth was of recent date, prided themsclves on the massive gold of their rings. Martial (xi. 47) ridicules an upstart, who wore on his finger a sardonyx set in a ring which contained a pound weight of gold; cf. Mart. Xiv. 123.

As a rule subjects from contemporary history were scldom used for Roman gems, even during the later Republican period, when such subjects were common on the rearses of 
the denarii. Pliny, however, tells us (IIst. Nat. xxivil. B) that Sulla used as his signet a sem engraved with the surrender in ro6 B.C. of the Numidian King Jugurtha. Sulla also, according to Dion Cassius, used a gen with three trophies in allusion to his triple victories: this device also occurs on the re'i'ysi of one of his chenarii.

The same signet derice of three trophies was cut on the ring of Pompey the Great, which Julius Cacsar showed to the incredulous Roman Senate as a proof of Pompey's defeat and death; see Dion Cass. XLII. is.

Another design, according to Plutarch, was sometimes used by l'ompey, namely a lion holding a sword ( $\lambda$ éwn $\xi(\phi i p \eta s)$. It is interesting to note that the reverse of a rare gold coin struck by Marc Antony about 39 1:C. bears the same subject-a lion holding in its upraised paw a short sword or dagger, possibly copied from the famous signet of l'ompeius Magnus', who was one of the earlicst Roman collectors of engraved gems.

The Roman Emperors secm to have had special curators of their gem cabinets. In the Columbarium of the lmperial freclmen, outside the Porta Capena, a sepulchral inscription was found over the ashes of "Julius Philargyrus libertus at dactyliotheca Caesaris." Another official was the keeper of the Imperial Signet, custus anmuli, an office which was huld in the time of J. Caesin by the father of Trusus Pompeius (Justin, XLll. 5): "annuli curam habuisse" is the phrase used by Trogus.

Accorling to Capitalinus, the whole collection of gems formed by Hadrian was sold by Marcus Aurelius, together with other valuable works of art, by public auction in the Forum of Trajan, to pay the cxpenses of the war with the Marcomanni.

One of the most interesting collections of ancient rings is that formed by the celebrated naturalist Waterton, the greater part of which is now in the South Kensington Muscum. Among them are some magnificent examples of signets with

1 This curious coin is illustrated by Stevenson, Mitionary of homan Coins, Londun, 1859, p. 58 . 
Watcton the bezel in gold, engraved with fine designs of Egyptian, ringss. Greck and Etruscan workmanship.

The following are among the most remarkable; a large Egrytian gold ring of Ptolemaic date, which has a i'sicashaped bezel with a minutely cut, seated figure of Isis sucliling the infant Horus.

$A$ Greek ring of the finest period of art, 5 th century I,.C., all of gold, has a rery beautiful female head with no distinguishing attribute-possibly representing Hera, most exquisitely cut on the gold bezel.

Another Greek ring of c. 400 1.C., which is wholly of bronze, is remarkable for its fine fortina and perfect state of preservation. On the bezcl is cut a seated female figure with most gracefully designed drapery.

Among the Roman rings are examples in a great variety materials. of materials, gold, silver, bronze, lead, iron, amber, stone, such as rock crystal or chalcedony, glass, ivory and even cnamelled pottery.

One curious ring is cut out of a piece of amber; in it is fixed a fine yellow paste intuglio with a head of Jupiter Ammon. In many cases the bronze and iron rings have their gem backed with bright metallic foil, in order that the dark metal might not diminish the brilliance of the stone: cf. Pliny, Hist. Next. xxxvil. Io6. Several of the rings are of very small size, being intended only to reach to the first joint of the finger: such rings have often wrongly been taken for the rings of children. It is unfortunately very rare to find a really fine $\mathrm{gem}$ in its original setting, most ancient rings which now exist have engraved gems of rather poor design and workmanship.

Under the Empire, as the old restrictions with regard to wearing rings gradually passed away, an cnormous quantity of cheap gems seem to have been engraved. Among the commonest subjects are single figures of the various deificd abstractions, which the Romans invented very freely, and also adapted from the Grecks.

Figures of Salus with her serpent, Fortuna with cornucopiac and rudder, Abundantia, Indulgentie, Felicitus, Bonus 
Eachtus and many others are constantly repeated on the inferior Roman gems, in exactly the silme forms ats on the reases of the Imperial denarii and aurei. The older deities, such as Jupiter, Juno, Minerva, Roma and others are no less common, and have the same close relation to the rearsi types of coins.

Another farourite Roman device for signet-gems is some form of what is usually called a gryllus, a composite monster made up with much ingenuity by joining togrether masks and rarious animals: see No. go in the Fitaidillam Catalogut.

According to I'liny (Ilist. Nat. Xxxv. I I 4 ) the fimous Gracco-Egyptian painter Antiphilos, who executed a number of fine pictures which were bronght to Rome to adorn the Porticus of Philip and that of Pompey in the Campus Martius, ilso painted a ludicrous figure known as the Grollhs. Hence, Pliny says, the name grylli was given to pictures of that comic class. The word also means a glatshopper or a cricket. It is still uscd in modern Italian for fanciful and grotesque figures.

In the first century A.1., Pliny says (Hist. Nitt. xxxill. $4 \mathrm{I}$ ), the fashion came in to Rome of wearing gems cingraved with at figure of Iarpocrates or some other Eegyptian deity. Among the many new sects which flourished under the Roman Empire, that of the worship of Isis and Serapis was the most popular; and even as early as the time of Augustus it was an important cult in Rome. A large number of Romano-kgyptian gems now exist: see Nos. IO4 and IO5 in the Fitarillium Cataloguc. Figures of llorus or l Iarpocrates, the grod of Silence, of which No. 20 in the same collection is a good example, were much used for signets, probably as at hint for cliscretion and silence with regard to the contents of the letter or other document that it was used to seal'.

Astrological gems, engraved with a lucky horoscope, were also very largely used under the Roman Empire, when superstitions of all kinds were specially rife.

In the second and third centuries A.I. Nithraic and Gnostic

I A mudiaeval analogy is the common tyje of seal engraved with the words "lecta lege: tecta legu."

Phatis 1 . and $I I$.

Astroloricat sims. 
Thlis. types were very common; especially gems engraved with the mans. mystic sun-god Abraxas and the Demiurgus Cnoubis: see No. 106 , Fita. Mus. Cot.

These and many other devices were highly valued throughout the Imperial period as having talismanic or magical powers of protection and grood luck; - the power of the talisman depending partly on the device, partly on the stone it was cut upon, and lastly on the season or planctary hour when the gem was engraved. Such gems were called by the

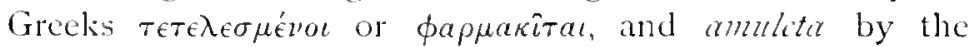
Romans; see l'liny, Hist. Nat. xixvin. i s.

Wetalli In some cases metal signets of this class have a little dot anulits. or pin of gold or silver let into the freld; the union of two metals giving an additional talismanic virtue to the device. This may possibly have originated in the accidental discovery of the mysterious galvanic effect which is produced when two adjacent metals are touched by the tongue. This would naturally be noticed in those not uncommon rings which have the bezel made of one metal and the hoop of another.

Sityles of $\mathrm{s}_{\mathrm{c}} \mathrm{m}$ intsuatings.

Cinns set in rings.
With regard to the style of Roman gems, the fincst, both in intaglio and in cameo, were produced under Greck influence, if not by Greek artists, during the Augustan age. It is noticeable, as has been already remarked, that in many cases fine gems of the Roman Imperial period are engraved with copies of statues, whereas during the best Greek time the designs on gems were specially devised for glyptic purposes. During the Flavian period the work was, as a rule, inferjor in style and coarser in execution'; but a few years later, in the time of I Iadrian, there was a remarkable revival both of good taste and of technical slill, which came to a rather sudden end about the close of the second century A.D. in the reign of Septimius Severus.

After that, the decadence of gem engraving, lilie that of the other arts, continucd without intermission. IIence arose, in the third or fourth century, the not uncommon fashion of wearing in rings and other ornaments fine gold coins

1 The prortrait of Julia the daughter of Titus by Luodon, in the Paris Biblio. theyuc, in a rematiable exception to this mice. 
(amei) of the earlier Emmerors, instead of a bally cugraved contemporary gem, a custom which was imitated by people of Celtic and Teutonic race in much later times.

This however did not bring the engraving of gems to an end: the art still was lirgely practised, though the old skill was lost, both in techniepuc and design.

By the time of Constantine, at the beginning of the fth century, gem engraving in Rome had, like all the other arts, stnk to its lowest ebb; and the craftsmen of Byzantium, skilful as they were in enanelling and working in the precious metals, seem not to have very largely developed the glyptic art, even during the wonderful outburst of technical skill and artistic excellence which took place in the time of Justinian, in the early part of the 6th century 1.J.

Christian gems of the Roman period are, as a rule, of very poor workmanship.

Christun se'ms.

The commonest subjects are Christ the good Shepherd, represented after the old pagan types of llermes Psychopompos or Orplueus playing to the listening beasts-subjects which frequently occur among the early Catacomb paintings.

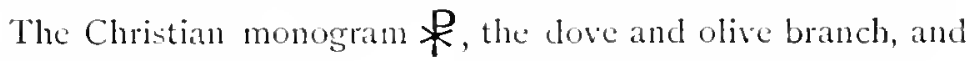
other symbols of this kind were very often cut on gems of the $4^{\text {th }}$ and $5^{\text {th }}$ century.

A very fine Christian sem worked with exceptional delicacy has a standing figure of a winged Victory ${ }^{1}$ holding a tall cross, a design copied from a not uncommon rearsi on a sold solidus of Ilonorius, c. 412 A.I). This gem is in Dr Drury Fortumn's cullection, one of the finest in the workl for its Christian gens and rings?

1 It interesting to note that the usual mediacval representation of an angel appears to have been derivel, through many stages, from the winged Victory of the Greeks.

- Dr Fortnum has writen at various times many valualle papers an the smbject of Christian gems and ring, especially in the Archeoloriat fownul; nec

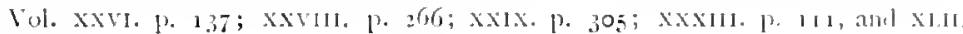
1. 159 . 


\section{Sasanian Gems.}

Sistutidn Dynasty.

Malerials (t)et forms of $\mathrm{g}$ ims.

Woslem sems.
During the lowest period of artistic decadence in kome, a great many large but feebly cut genns were executed in Persia under the successors of the Achacmenictae, from the third century A.D. down to the Moslem conquest of Persia in 632 . The finest of these have portrait busts of the King, frequently a Shapur or a Hormizd, or of the Quecn, with name and titles Orgin of in Pehlevi characters. The name Sasanian is derived from a man called Sasan, a supposed ancestor of Ardashir, the first king of this dynasty, who began to reign about 212 A.1.

The Persian gems of this period are frequently large and decorative in style, though poor in the details of the design and coarsely cut. A great part of their beaty depends on the fact that usually they are cut on carnelian, rocli crystal, amethyst or carbuncle of very fine and brilliant quality. In most cases the gems are convex, either in front or at the back.

The conical and the scarabacoid forms were used occasionally in Persia, even at this late period, especially when the material employed was chalcedony; No. 24 in the Fitsailliam Cotulogue is an example of this, as it is also of a favourite Sasanian class of subject-that of hunting scenes, the king on horseback attacking lions, boars, stags and other animals Some large Sasanian intaglios are cut on unusual materials, such as turquoise and lapis lexali. Both these magnificently coloured stones of very fine quality are largely found in Persia. Persian lapis lazuli is the finest in the world.

In the year 632 1.1). the fanatical disciples of Mohammed conquered the degenerate successors of the warlike Achaemenidae, and thenceforth the signet-gems of the Persians have been mostly engraved with names or pious sentences, owing to the precept of the Koran which again introduced the old Mosaic law forbidding the likeness of any living thing to be represented. In later times the Persians adopted a modified form of the Moslem jaith, and, to a large extent, have ignored this prohibition-much to the horror of the orthodox Sunni sects. 


\section{CIIAPTER V.}

\section{Caneo Gens.}

IN addition to the usual signet-gem with its device sunk (intaglio di caro), there were, especially under the Roman in ritiof. Empire, a certain number of gems cut in relief, which were intended, not for impressing seals, but for use as ormaments. This is what is meant by the modern word camo', a name which is probably of Arabic origin. Such works in relicf were included by the Greeks under the name rumor éryer $\lambda$ v-

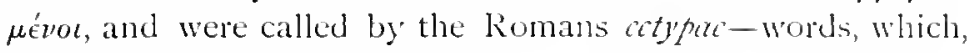
howerer, were applied to reliefs in metal and other materials as well as to cameo gems.

l'liny (Hist. Nat. Xxxil. 173) describes certain stones as being especially suited for canco cutting- "Gemmae quac ad ectypas scalpturas aptantur." One of the earliest examples of the mention of a ring-cannco by a classical author is in a passage of Sencca (Di licheficiis, IIl. 26), who speaks of a man wearing a camco portrait of the Emperor-"Tiberii Caesaris imagrinem ectypam atque cminente gemma."

The oldest existing examples of cameos (not including Earlest ligyptian work) are some curious gems of the Gth century lic., with a Gorgon's mask or other figure cut in very slight relief, frequently on the back of a scarab instead of the usual beetle form ${ }^{2}$. An example of this rare class of gems is mentioned below at page $8 S$, as being signed by its ingraver.

I In mediaeval documents spelt also camahuam, chamah, ramant, amahicu and in many other ways.

* Two characteristic examples of early cameos are illuntrated in the foum.

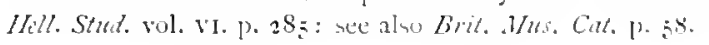


Grick camios.

Camious int sard

Thalurai camtios.
Some very fine cameos of this kind were found in the tombs at Kertch, dating about 400 1.,C. or rather carlier: for example a gold swivel-ring with a scarab-shaped carnelian, but having the back cut in relief, into the form of a slecping lion: the flat side has a running lion, in intaglio.

Another similar scarabacoid, with a lion cameo on the back, has on the reverse a trophy of arms: sce $A n t$. du bosph. Cimmiricn on Musier de l'Ermitage, Pl. Xvil. Nos. 8 and II. Another ring from a Kertch tomb is set with a cameo head of Athene cut in deep red carnelian. It was found on the skcleton hand of a lady who wore eight rings.

These early cameos are mostly cut in sard, carnelian or some other stone of homogencous colour, but the later camcos of Roman date are mostly cut on sume stratified stone, such as the ony $x$ or sardonyx, in order that the design might be cut in one stratum, and be set off by having its background of another colour.

One of the most important clitsses among the Roman cameos are large, full-faced heads of Medusa or Jupiter, carved in a thick piece of ony $x$ or sardony $x$, and used to ornament the fluaterex in the middle of the bronze cuirass of an emperor or gencral of an army. The Medusa's head was often inlaid in the weris which formed a principal ornament on the imperial cuirass. A very beautiful example of this was dredged up in the Tiber in Rome in 1886 , and is now in the possession of Dr John Evans, P.S.A, see Procud. Suc. Ant., vol. xi. 1887, p. 396. It is cut in bold relief on a very thick piece of ony $\mathrm{x}$, which measures about $3 \frac{1}{ \pm}$ inches across. The British Museum possesses a very fine Gorgon's head cut in high relief in a brilliant amethyst, which was probably a similar ornament.

A few Roman camcos exist of very great sizc, some as much as from 10 to 12 inches squarc. The most famous are the "Coronation of Augustus" at Vienual, and the "Apotheosis of Augustus" in the l'aris Bibliotheque. Both are claborate

1 The Vienna collection is specially lich in koman cameos of great size: a large circular cameo of an eagle is stecially magnificent, measuring about 9 inches in diandels, and very nothe in design. 
compositions, with many figures in two or three tiers, evidently designed and executed by some very skilful Graeco-koman artist.

The Vicnna camco was bought by Rudolf I I. for a sum equal to flo $_{1000}$ in molern money.

The Apothersis of Augustus was, according to a probably correct tradition, given to the Treasury of the Sainte Chapelle "Cinmion in l'aris by Lonis IX. shortly before the middle of the I 3 th century:

In a Latin inventory of the precious objects in this treasury dated $\mathrm{I} 3 \mathrm{f}^{1}$ it is described thus:-"Item. Unum pulcherrimum cammot in cujus circuitu sunt plures reliquiac." In later inventorics it is called "le srand camahicu de france." In I $3+3$ Philip VI. lent it to the Pope, but in 1379 Charles V. restored it to the Sainte Chapelle. This masnificent cameo had becn mounted in an claborate frame of gold and cnamellal work of byzantine style, containing cavities, closed with plates of rock-crystal, in which various relics were prescrved; but unfortunately this beautiful frame-work was lost in I 804 , when a party of burglars broke into the Bibliotheque and carricl off many of its most precious objects, including a priceless collection of large Roman medallions both in gold and silver.

The cameo itself was recovered, but its setting and the other objects in the precious metals perished in the melting pot; scc kanc Arikio. r. Is 48 , p. Is6.

Another historical cameo in the Bibliotheyue is the socalled "Apotheosis of Germanicus", with a figure crowned by a Victory and borne up to Heaven on the back of an eagle, the usual Roman way of representing the Apotheosis of an Emperor or Prince. This large sardonyx gem was for many centurics in the possession of the Abbey of Saint-Evre; but in I6St the monks sold it to Louis XIV. for his collection of sems, which he was then transporting from Versailles to the Palace of the Louvrc.

The King gave the monks the enormous sum of 7,000 gold écus for this camco-equal in modern value to more than double the number of pounds sterling.

Camin of Girmatamists. 
Cameo Fupitur.

Camio inh.

A third camco in the same collection in Paris also has considerable historical interest ${ }^{1}$.

It was given to the Cathedral of Chartres in 1357 by King Charles V., as is recorded in one of the inscriptions on the gold enamelled frame which still surrounds the gem. This cameo, which is cut in sardony'x, has a standing figure of Jupitcr holding a sceptre and thunder-bolt; at his feet is an eagle, on account of which the camco was venerated in mediaeval times as representing St John, the eagle being taken for the Evansclist's symbol.

Till the Revolution in 1789 the cameo remained in the Cathedral treasury at Chartres.

The so-called "cup of the I'tolemies" is also now in the Paris collection. This is a large two-handled cantharts, cut out of one immense nodule of sardonyx, and covered on the outside with cameo reliefs of various Dionysiac figures and symbols, of rich decorative effect, though not designed with very good tastc. It is a purcly Roman design of the first or second century A.D.

This very remarkable cup was given in the gth century by ne of the Carlovingian Kings to the Abbey of St Denis, where it was occasionally used as a chalice at Mass.

At the coronation of the Kings and Qucens of France it was an ancient custom for the Queen to take the "housclsip" of consccrated wine from this cup".

Lilic the "Apotheosis of Augustus," this cameo-encrusted canthamus was stolen in 1804 , and then lost its claborate grold font, though the cup itself was restored to the Bibliotheque, when the burglars were arrested in Holland, whither they had escaped with the non-meltable portion of their spoil.

On the whole the fincst Graeco-Roman cameo in the world is in the form of a large circular fatero of translucent agate, $S$ inches in diameter, in the Muscum of Naples. It has

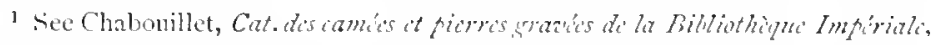
Paris, 1858 , page r, no. 4 .

Long after the consecrated wine was, as a rule, whtheld from the laity, the sovereigns of France at their Cormation-hlas continued to receive the sacrament in lusth kinds, an interesting survival of rery primitive times when the offices of King and l'riest were hele by the same man. 
a camco relief on both sides; onc is a magnificent head of Medusa, and on the reverse side is an allegrorical subject Camear of representing the Nile as the source of the fertility of Esypt. Both in design and cxecution it is a work of remarliable beauty, far superior in treatment to the more famous cameos of Paris and Vicnna.

It has unfortunately becn damaged by having a hole clumsily drilled through its centre; otherwise it is perfect.

The British Muscum possesses a very noble portrait-bust of Augustus in profile (No. 1560 ) illustrated as frontispicce to Mr A. H. Smith's Cataloguc.

It is cut boldly; in a very good style, but without much minuteness of detail, in a sardonyx of three layers measuring 5 inches in height. On the breast an ageis is represented with central fhalerac with the Medusa's head, like that in Dr Evans' collection.

The most beautiful Roman cameos, which are usually of much smaller size, are portrait-heads of Emperors, Empresses and other members of the Imperial family.

One of the finest in the British Museum is a profile bust of Julia, the daughter of Titus (No. I607 Prit. Mus. Cat.), apparently copied from the celcbrated intaglio signed by Enodos.

This cameo may, however, be the work of one of the very skilful gem-engravers of the last century.

No. 43 in the Fitzwilliam Collection is a well designed, but somcwhat coarscly cut bust of Juno in ony $x$, dating probably from the carly period of the Roman Empirc.

A fow gems cxist, caprices of the Roman engravers, which combine intartio and cameo; as, for cxample, one in the British Museum from the Blacas collection (No. 1568) which has an interglio portrait head of the Empress I.ivia in the character of Ceres, surrounded by a border with the symbols of the other chicf deitics cut in relicf.

Besides the use of large camco heads for the fhalerae of Imperial armour, they were also made to ormament the massive fibule or bronch which fastened the Emperor's cloak (perudamentum) on one shoulder. They were also wised in a lavish and often tastcless way for many other ormamental 
6. CAMEO ENGRAYNG IN STONE ANI PASTE. [CHAP. V.

camcos on purposes by the purse-proud Romans. Tomb relicfs of the armonr. 3 rel and fth century A.D. sometimes show the cuirass studded with five or six big camcos; as, for cxample, the monument of M. Caclius in the Muscum at Bonn. A few of these large cameos have additional life and transparency given to certain parts of the relief by having a cavity cut out at the back, so as to partially reduce the thickness of the translucent $\mathrm{gem}$.

This is the case with the Medusa head in chalcedony in the Marlborough Collection, No. IOO, one of the finest phaterac gems known.

On the whole the Roman love for cameos cut out of stratified gems had a degrading infuence on the glyptic art.

Methot of armo cullines.

Cameos of shiss.

Final tooling. It was rather a tricky sort of ingenuity that was fostered by the wish to have gems with the design worked out of three or four layers of different colours, the backgromel being one colour, the flesh of the head another, the hair a third, and perhaps a wreath round the head in a fourth, the uppermost stratum. Great skill is often shown by the way in which the artist has designed his subject to suit the successive layers of varied colour, but he was usually scriously hampered by the exigencies of the thin strata; and work of this claborate kind has an awkward flatness of modelling, and necessarily a complete want of graceful molulation in passing from one plane to another of the relief. However, cameos such as these are showy and highly decorative at a distance, and that is what Roman taste seems to have preferred in all branches of art.

Paste Caneos: remarkable skill was shown by the Roman glass-workers in their copics of large and claborate ony'x cameos, executed in pastes of different colours fused together so as to resemble the various strata of the ony $x$ and sardonyx. The difficulty of securely fusing the relicf in opaque white paste on to a ground of differently colourcel glass must have been very great. The finest of these paste camcos have usually receired, after the glass was cold, a good deal of finishing work, executed with the various tools which were used in cutting real onyx. Without these final touches the relicf was liable to be blunt and spiritless in effect.

$\Lambda$ large number of cheap paste cameos, exccuted without 
any final tool-work, seem to have been made under the later Roman Empire, with glass of two or more colours to imitate the stratified gems such as ony and sardonyx.

Several antique examples of these paste cameos were used, about the year I 300 , to decorate that masnificent painted and cnamelled retable, which was made for the high altar of (amios an mélitical shivises. IVestminster Abbey, and is still preserved in the south ambulatory of the choir.

This mediacval use of antique pastes and also of real stones was rery common, especially for retables, reliquarics, and even rings. Many fine camcos (ctmerhutu), some of great size, were among the numerous antigue gems which Henry II I. used to decorate the magnificent gold shrine of lidward the Confessor, and many other gems were hung round the shrine

Hestminsti\% Alliey. as rotive offerings.

Almost every mediacval shrinc or reliquary of any importance was more or less enriched with antique gems, both in cameo and intaglio.

One of the most important cameos in paste is in the Vienna collection-a fine head of Augustus in blue glass, with the signature of Herophilus the son of Dioskourides, incised on the ficld?

The British Muscum possesses a large fragment of a paste camco (from the Townley collection) of quite a different class - not a copy of an engraved gem, but rather of the nature of a relief for mural decoration. This magnificcnt slab or tablet has in high relief a nude figure of a youth, representing Bonus Eventus, which must have been (when complete) seven or cight inches in height.

It is Greck in style, modelled with great skill and taste, and is formed, not in a stratified material with differently coloured layers, but in fine blue paste, speckled to imitate lapis lazuli. It has first been formed in a mould, and has afterwards been worked with the ordinary gem-engraver's tools, exactly in the same way as if it had been a real piece of lapis lazuli. In beauty of colour and in excellence of finish it is quite as fine as if it rere a real stone cameo.

1 This cameo is clescribed below at page 76 . 


\section{CHAPTER VI. \\ INSCRIPTIONS ON GEMS.}

I. The OWNer's NhME: Egyptian scarabs, Assyrian cylinclers and a certain class of Phoenician gems very commonly have on them the name of their owner, in the first case in hicroglyphs, in the sccond in cunciform characters, and in the last in the early characters, prototypes of the Greek and Latin Alphabet, which were uscd in common by various Semitic races, such as the Jews, the Phoenicians and the people of lloab. One of the earliest of existing Semitic signet. inscriptions (shown on fig. 20) is the name Haggai bon Shebeniah, cut in two lines on a small gem found near Samaria by the Palestine Exploration Society. The date

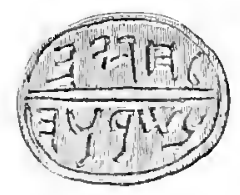

FIr. zo. Signet of Semitic type, with no device except the owner's name in l'henician or Helurew characters of the earliest form, dating from a tine when the same alphabet was used in common by the Jews, the I'hoenicians and other neightrouring scmitic races. The cut is nearly douth the mal sixe.

of this interesting signet is about the gth or Sth century B.C. The owner was probably a Jew'. Many Phoenician gems

1 The description of Aaron's lreat-plate in the Book of Exolzs (xxviii. 1; to 21), specially recorts that its gems were engraved with the name of each tribe "like the cngravings of a vignet," lmu these stones were, most prolnaly, of l'hoenician workmanship, as was the whole Temple of Sulomon with all it ilecorations and fitting 
with the ouner's name lare been found in various far distant places: one was even discovered a few years ago on the south coast of Ireland.

Owners' names rarely occur on Greck sems of the best period; and the carliest Greek gems-those of lenticular form-date from before the introduction of writing among the Grecks, and therefore have no sort of inseription. An carly example of a gem with the name of its Greck owner is No. 4 in the Fitwalliam Cataloguc, the agate scarab of Phocnician type which is mentioned abore at page I4; in the ficld is cut, in characters of the carly part of the 5 th century B.C., KPEONTI $\triangle A$ EMI, "I am the badge (or signet) of Kreontidas," the word $\sigma \hat{\eta} \mu \alpha$ (or $\sigma \phi \rho a \gamma i s$ ) being understood.

In the Berlin Museum is a fine scarab in black jasper, with a kneeling figure of a nude girl holding a hytria under Scarali of Simon. the jet of water which issues from the lion's head spout of a

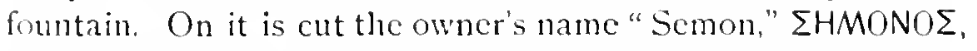
in characters of Ionian style. This very fine example of archaic work was found in the Troad: its date is probably a little earlier than the gem of Kreontidas, about the end of the Gth ecntury I.C.; see Falubuch Ard. Inst. ISSS, p. I IG, and l'late 3 , No. 6 .

An carlier example of this class of inscriptions is on a very remarkable little scarab of the 6th century I.C. Which is published in an interesting paper on early Greek gems by Rossbach, Archeol. Zit. I $88_{3}$, p. 3 I seq. and J'late I6, No. 19. On the undersice of the scarab is the following inscription, which occupies nearly the whole of the ficl, ORPSIOS EMI

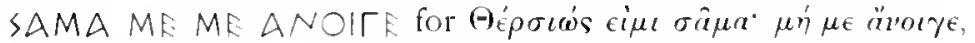
"I am the device of Thersis; do not open me." At the cnd of the inscription is the 'device'-a very small dolphin.

With these inscribed gems it is interesting to compare that very curious clectrum stater probably struck by a l'ersian Satrap named l'hanes, c. 600 B C, with, on the obiersi, a stag feeding and the legcnd in coarsely cut retrograde characters ФANNO? R.MI SBMA-meaniner (according to l'rof. Gardner) "I am the derice or badge of Phanes"."

\footnotetext{
1 Profenson Garemer in inclincel to ntublute this remakkale stater to a satrap
} 
Nitules on tamles. rate t. scarabacoid by Dexamenos (No. I I, Fitwaillim Cortuloguc) bears the name MIKH $\Sigma$, possibly the name of the lady who owned the gem'; see above, page $2 S$.

Nimes an Roman $s^{\mathrm{s}} \mathrm{c} m s$.

A similar phrase occurs on many Greck scpulchral inscriptions, as, for example, some found in Cyprus with the name of

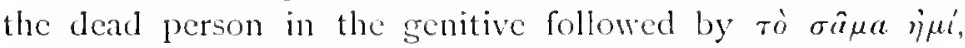
written in the peculiar Cypriote syllabic characters: sec zour. Hell. Stud. Vol. xi., 1 890, 1. 67.

On Greck gems of the $4^{\text {th }}$ century B.C. and later the owner's name is rarcly inscribed. The very fine fth century

On Roman gems both of the Republican and of the Imperial period owners' names are very common.

Not unfrequently the Roman name is cut in Greck letters, as in the case of the culcbrated Diomede with the Palladium by Felix, described below at page 75. The nominative and possessive cases are both used for the owner's name on Greck as well as on Roman gems.

Except the gem of Thersis, which has the word $\sigma a \mu a$, no word for 'srem' or 'signet' is added after the owner's name. A head of Athene on a sard in the Barberini collection in

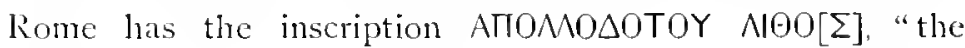

of IIalicarnassus (where the coin was found) naned Phanes, who in 525 B.c. revolted against the Jersian king Cambyes and joined the army of the Egyptian ling Amasis: see 1 teror. In. 4 .

The form of the letters of the imscription is, however, clearly earlier in date than $525 \mathrm{k}$ k.e. and the type-a stag-would suggest that the coin was struck at Ephesus; see llearl, Hist. Num., page \$26. The only known example of this stater is in the British Museum.

It is pomille that this is a memorial gem, jutging from the sepulchral character of its design, in which case Nike may be the name of the deceased larly who is represented on it.

This unusual female mame Miki or Mika oceurs on a votive relief, now in the Central Musem of Athens, which represents the guteless Cybele, "the mother of the grods," seated in a throne. At the siales of the relief are small fugures of a male and a femate worthipper; and above them is the following dedicatory in-

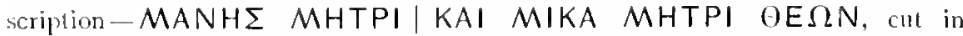
letter of alwut the midule of the fourth century $1 . .6$ or rather earlier; probably the same date, that is, as the lady represented on the scarabaenid of Dexamenos in the Fitzwilliam Museum.

The relief is ilmutated by Miss llarrison in her valuable work, the My/hology and llyths of thons, London, isyo, page 45. 
gem of Apollodotos," but this gem is of very doubtful authenticity.

In some cases, when the name is in very small characters, it is uncertain whether it is that of the engraver of the gem or of the owner: the latter is, as a rule, not only in larger letters than that of the artist, but is also placed in a more conspicuous position.

2. Tile ARTist"s Nane. To decide which are genuine among the many so-called artists sisnatures on ancient grems is a very difficult problem, and one which has been discussed by various writers with very different conchusions.

In the first place it will be well to consider what record we have in classical writers of the names of gem-engravers,

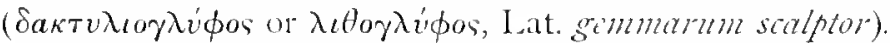

The list is a short onc. Iirst comes the celcbrated Therdoms of Samos, one of the most distinguished arehitects and sculptors in bronze and the precious metals of about the midelle of the 6th century B.C., who is frequently mentioned as working in partnership with Rhuecus, or with Telecles, who were also Samians, and probably ncar blood-relations of Theodorus, though in what precise desree is very doubthul.

Theodorus appears to have been specially skilful in metal work, and is mentioned as the inventor or improver of various processes in the manipulation both of bronze and iron: sec Pausanias, VIII. $14 \$ 5 ;$ X. $3 \$ \$ 3 ;$ III. $12 \$ 8$.

According to Pliny (Hist. Nat. vil. 57), Theodorus was the inventor of various tools for working in wood, namely the norma (set-square), libilla (level), torms (lathe), and claris (perhaps a vice): all of which tools were certainly in use lons before the time of Theodorus; see also l'liny, Hist. Nat. XXXY. $152^{1}$.

As a sem-engraver the fame of Theodorus rests chicfly upon the celebrated engraved cmorald, set in a gold ring

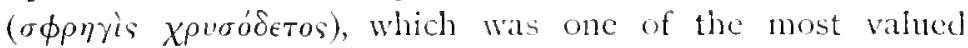
possessions of Polycrates, tyrant of Samos, who was crucified in 522 I.C. The whole story of the ring of I'ulycrates is told

1 l'liny's statements as to the inventors of procesies in the arts must always be receiver with caution. In most cases they are olviously erroneous. 
at length by Herodotus, III. 38 seq.; and is mentioned by Pliny (IIist. Not. XXxvi. 3 and 4 ) with reference to an uncut sardonyx in the Temple of Concord in Rome, which was popularly supposed to be the gem of this dramatic story: see above, pagre 35. In another place (Hist. Nat. Xxxiv. 83) Pliny describes a bronze portrait statue by Theodorus of himThedorns.

self, holding in onc hand a file or scraper (lima) the symbol of his craft, and in the other "a quadriga and driver, so minute that they were covered by the wings of a fly."

The real meaning of this impossible statement was pointed out by Di Benndorf (Zitschrift fiir Oestrmich. Gymnasicn, I 873 , p. 4 OI sq.), namely, that it was simply a scarab-gem engraved with a quadriga that the artist's statue held.

Most of Pliny's information comes at second or third hand, and the blunder would easily be made'.

This story, rightly read, tends to show that Theodorus regarded gem-engraving as an important branch of his art", since he represented himself holding a scarab-gem, as a specimen of his skill. Most probably there was more than one distinguished Samian artist called Theodorus, so that the various inventions which are attributed to this name should be refered in part at least to an carlicr Theodorus than the contemporary of Polycrates, possibly a grandfather of the later artist, as the common Greek custom was to name a son, not after his father, but after his grandfather-a very fruitful source of confusion in the literary recolds of artists.

Mneser. Another Samian gem-engraver of the first half of the 6 th chus. century, about whom almost nothing is known, was Mnesarclus the father of the culebrated philosopher I'ythagoras; sec Herod. IV. 95; and Aristotle quoted by Diog. Laertius, VIII. I.

The only gem-engravers mentioned by Pliny (see Ifist.

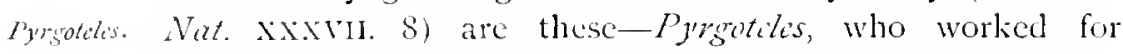
Alexander the Great, and was (according to the above passage) the only engraver who was allowed to cut the

1 Pliny mentions (Kist. Vat. xxxit. +3) another Quadriga corered by a 1ly's

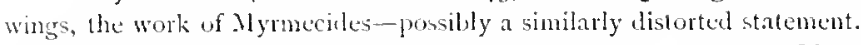

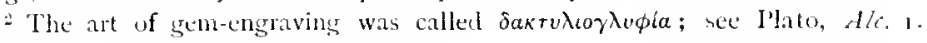
$128 \mathrm{c}$. 
portrait of Alexander on an emerald-"vetuit in hac gemma /yrsotits. (zmaragdo) ab alio se scalpi quam a l'yrsotele."

In an earlice passage (Hist. Vat. vil. I25) Pliny secns to say that l'yroteles was the only artist who was permitted to make a marble statuc of Alexander-" Idem hic $1 \mathrm{mp}$ erator" (Alcxander) edixit, ne quis ipsum alius, quam Apelles, pingeret; quam Iyrgoteles, sculperet; quam Lysippus, cx aere duceret;" cf. Ior. Ep. II. i. 239.

Apulcius (Florid. lib. 1) tells us that Alexander's edict was that "solus I'yrgoteles caclamine excuderet:" a phrase that could not apply to sem-engraving, but must mean hammered, repoussé work of some kind, probably in the precious metals.

With these conflicting statements all we can gather with any degree of certainty is that lyrgoteles was a gem-engraver, and that he had the monopoly of executing portraits of Alexander in some form or material.

In the same passage (H. N. Xxxvi. S) pliny names three other distinguished gem-engravers as being subsequent in date to Pyrgoteles-Apolloniles and Cronius, about whom he tells us nothing, and Dioscurides, who engraved the portrait of Augustus, which subsequent emperors used as it signet.

Pliny states (Hist. Nat. Xxxv. 156) that the celebrated sculptor Pasitiles, in the first century i.C., also practised the art of scalptura, meaning probably gem-engravingr.

The names of two other gem-engravers are known only from epigrams preserved in the Greck Anthologia. Satyrius who engraved a portrait of Arsinoc of Esypt on crystal; Anth. IX. 776; and Tryphon, who cut on beyt a swimming figure of Gallene; Anth. 1x. 544.

The number of existing gems which have what profess to be artists' signatures is very large, but the great majority of

Portraits of Hit $x$. ander.
Othr Artisis.

1 In the Devonshire collection there is a fingmenlary intaglo on sam engraved with a cow lying down, under which (in loce extsze) is the signature $A \Pi(O \wedge \wedge \Omega$ NISOY, in incised letters. It has been wrongly tescribed by Dr biun and uthers, as a camio on onyx.

The inscription is not above suspictun, more especially as the I tuke of Thermshire bongle it from the notoriuns lyaron stowch, fo whom he pail the enomons sum of 1000 grincas, for the sake of the signatne of the famens Apollonides. 
these are certainly not genuine. In many cases both the gem itself and the signature are forgeries, but a great many genuine gems exist on which a signature has been added by a modern hand.

Ever since the revival of interest in antique gems and their engravers about the time of Lorenzo de' Medici (I+49I 492), the value of a genuine stone has been enormously increased by its possessing an artist's signature, and therefore unscrupulous dealers ever since the igth century have been Forsut, in the habit of adding the name of some real or supposed

Artists nitmits.

Gims of Disal minos. grlyptic artist on to the grems they wished to sell, whether they were genuine antiques or modern forguries.

This rage for artists' names on gems was specially prevalent during the eighteenth and the first half of the present century.

In many cases the signature has been forged with great skill, and owing to the mechanical process by which it is cut and its minute scale, it is very frequently quite impossible to decide whether a signature is genuine or not.

The most diversely different conclusions have been arrived at by many archacologists, such as Kühler, Stephani, Brunn, Benndorf, Clarac, Chabouillet and Furtwängler, who have written on the subject of signed gems'. Any absolute certainty on this matter is practically unattainable, and almost the only signed gems, about which there can be no doubt, are those which have been found by some trustworthy explorer and have never passed through the hands of a dealer, such gems, for example, as the two cranes of Dexamenos, found at Kertch, the ancient Panticapaeum, and now in the Hermitage

$1 A$ long list of gem-engravers, real and imaginary, is given loy Clarac, Cata-

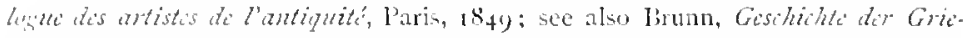

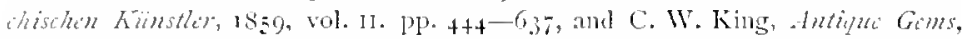

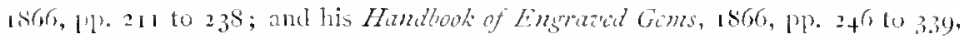
where he gives the gist of Kohler's, Stephani', and Brunn's treatises on the subject.

The best recent treatise on signed gems is Furtwängler's Gimmen mit Ainstlerinschiftu in the "Jahruch des Kaisentich Deutschen Archaologischen

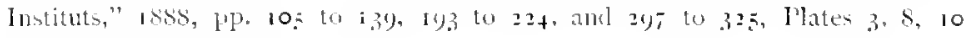
ancl 11, and osig, p. po. 
Museum at St Petersburgl. See page vii in the Appendix, where the gems of Dexaminos are described.

Another signet found in a sarcophagus in one of the Kertch tombs has what is probably an engraver's signature. This is a ring wholly of gold, on the bezel of which is cut a figure of a Scythian noble clad in a tunic and close fitting trousers with a Phrygian mitra on his head; he is seated on a chair, and holds an arrow in his hand. Like most of the other Greek objects from Kertch it is fine work of the 4 th century 13.C. In the field, in minute letters, is the name Athenades $[\mathrm{A}] \odot \mathrm{HNA} \triangle \mathrm{H} \Sigma$.

It is now in the Hurmitage collection at St Petersburs: sce Antiqu. du Bosp. Cimm. 11. 32, 1, and Compte Koulu. I 86 I, Pl. VI. I I.

The Museum in Naples contains a gold ring which was found on the site of the ancient Capua. Like the last mentioned ring, it is wholly of metal, and has a large bezel of mixed metal inlaid in the rold and engraved with a very noble portrait head of a clean-shaven Roman of midclle age, of fine Greek Workmanship of the Augustan period.

In the field behind the head, in very small characters, is

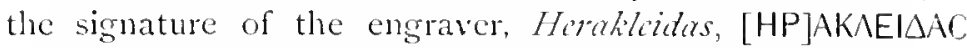
EПOEI: sec Bull. Inst. I\$55, Pl. XXXif. It has been suggested Sirnet of Hira. hilitilas. that the head is a portrait of M. J. Brutus.

Apart from the evidence of an ascertained frocinanc; signets which have the engraving on a metal bezel can be trusted far more safely than any engraving on stonc" ; unless indeed the latter is set in a ring which is evidently antique.

Even this test is not infallible, since in some cases gems set in ancient rings have been recut, as is mentioned at page

I Janticapaeun was a Greck colony in the Tauric Clersonesus (momlern Crimea): the population was partly sicythian and partly Ilullenic ly ace. It tomb have leen mont remalkable for their rich stores of oljects of all kints of the linest Greck worlimanship.

2 The reasun of this is that the sufter metal more readily slows signs of age, and, except in the cane of gold, wanally takes a surface fatina from axydiation which a forger can hartly initate. A hard btone, on the other lond. remains unclongerl by time, ame may be frec from all signs of wear.

Gold sisuets.

Sisnet of dilinitides. 
101, and ancient rings with plain gold bezels have had at modern derice cut upon them.

Again we may safely trust those signed gems which are known to have existed in some royal or ecelesiastical treasury from a period earlier than the date when forged inscriptions besan to be cut, earlier, that is, than the latter years of the 15 th century.

One of the most notable examples of this is the celcbrated portrait of Julia the daughter of Titus on a large and brilliant beryl or aquamarim; one of the noblest glyptic portraits in the world. It is signed behind the head with the artist's name Euodos, EYO $\triangle O C$ ETOIEl, reversed on the gem.

The history of this magnificent gem can be traced back for more than a thousand years. It was once in the possession of Charlemagne, and was given by Charles the Bald to the Abbey of St Denis, where it remained till the French Revolution, among the many gems which were attached as ornaments to enrich a gold reliquary. It is now in the Bibliothéque Nationale at Paris, No. 2089; see pagre 270 in Chabouillet's Catalogue.

Another signed portrait of Julia, of rather coarse workmanship, very inferior to that by Euodos, exists in the Marlborough collection (No. +47 ).

It is cut on a splendid hycinthine save of which the upper portion is broken away.

Vikandir. Behind the neck is the signature of Nikander, NIKAN $\triangle P O C$ EПOEI, of almost undoubted genuineness, though the gem lacks the confirmation of so satisfactory a pedigree as that of the work of Euodos.

Another signed gem in the Marlborough collection ${ }^{1}$ (No. 341 ) certainly appears to be genuine, though its pedigree loes not gro back further than the reign of Charles 1., when it formed part of the Earl of Arundel's collection.

It is a large clark sart, engraved with a seated figure of biomede holding the Palladium, and, on the right, is Ulysses pointing to the prostrate body of the Trojan priestess. On

1 In r8j5 the whole Marllorough collection of gems was sold for 35,000 graineas to Mr Bromielow of liatteselen Jark in Bedfordshire. 
the square cippus on which Diomede sits is the signature of the artist Felix, in Greck letters $\phi H A I \equiv$ ETOIEl; and in the Gionly field, over Diomede's head, is the name of the owner Calpurnius Severus, in the genitive case, thus-KA^ПOYPNIOY CEOYHPOY.

There are a great many replicas or copies of this gem more or less varicd; either with the whole or part of the design, and with rarious, probably in most cases, forged artists' names, such as Solon and Gnaios.

Furtwängler however accepts as genuine a comelion replica of this design which is signed $\triangle 1 O C K O Y P I \triangle O Y$, in the Devonshire collection, first mentioned by Dandelot in 1716 . This has only the figure of Dionede scated on a cubical ciffus with a sword in one hand and the lalladium in the other. In front of him is a statuette on a tall stele. The signature is in minute letters in the carroue; sce fahmuch Aroh. Inst. ISSS, p. 220 and Pl. S, No. 26.

By far the most beautiful of all the replicas of this noble figure, ancient or modern, is one from the collection of Lorenzo the Magnificent, with LAVR. MED. On the cubical ciffus on which Diomede sits.

It has a very wide margin all round, unlike the ancient fashion of filling up the ficld as much as possible, and is clearly a work of Lorenzo's own time by some unlinown artist of extraordinary skill : sec page i 25.

A variety of this design with Diomede rising from his seat is known from faste copies only, the original now being lost or out of sight; in the exergu is the signature of Solon, CONGN EROIEI, which may possibly be genuine.

The name $\Sigma O \wedge \Omega N O C$ on the celebrated chalcelony with Medusa's head from the Strozzi collection, now in the British Muscum (No. I 256), is certainly not a genuine artist's sigrnature. The same may be said of the head of Maccenas, with a similar inscription, which was published by Iiulvio Orsini in 1580 as a portrait of the Athenian Solon. On the last two gems the name, if not a modern addition, is probably that of the owner.

Few gems have such a good pedigrec as one which is Eutyches. signed by Eutyches of Acegacac, the son of Dioskourides. It 
thine is is a very nuble full-faced bust of Athene, decply cut on Euryches. a large amethyst, cvidently of the first century A.I., and copied from a statue. In three rertical lines is inscribed in minute characters-

\section{EYTYXHC $\triangle I O C K O Y P I \triangle O Y$ AITEAIOC Eח[OIEI].}

"Eutyches of Aesracae the son of Diosliourides made (this)." Apart from internal evidence there is docmentary proof of the genumeness of this gem. The Comm. de' Rossi discovered in the Vatican library, among the MS. writings of Cyriac of Ancona, a description of this very gem written in 1445 , with the inscription given in full and a Latin translation of it; sec liull. Inst. 1S7S, p. to; and Kins. Hemtboek of Goms, p. 2S4.

A gem exactly answering to this description exists among the Marlborough collection (see Marl. Gcms, Vol. 1I. No. 12), and is probably the one mentioned by Cyriac: it has unfortunately lost the last four letters by re-polishing and re-setting; see N. Story-Maskelyne, MLarl. Cat. I870, No. Si.

Camio by linophilus.
A large cameo in bluc paste with a very fine laurcated head of Augustus in very high relief, in the Vienna collection, is signed by IIcrophilites, anuther son of Dioskourides,

\section{HPOФI $\triangle O C$ $\triangle I O C K O P I \triangle[O Y]$.}

This gem also appears to have a good pedigree: it is in a mediacral setting, and is said to hare belonged to a Church in Germany many centuries ago. Father Wilhelm in his Luxcmlurgenn Romanum, written in the $17^{\text {th }}$ century, describes this cameo as being then in the treasury of the Church of Echternach. Drs Brunn and Furtwängler consider the signature to be genuine, in spite of the unusual spelling of "Dioskoricles."

Hyllus. The name of a third sun of Dioskourides called Hyllus occurs on some antique gems.

A sardony cameo in the Berlin Museum with a finely executed head of a young liaun hats the signature thus- 
YAAOC $\triangle I O C K O Y P I \triangle O Y$ EROIE. In most cases this name is

a molen forgery. Among the genuine examples may be ranked a sard in the St letersburg Muscum with an intaglio head of Apollo; in the field is the name Y $\wedge$ YY.

This gem was formerly in the collection of Lorenzo ale' Medici, and bears his name LAVk. MEL. cut in the usual conspicuous fashion.

The Bibliothieque at Paris contains a very fincly executed intaglio on chatcotony, a bull advancing with lowered homs, and decked out in Dionysiac ornaments. Above it, in the field, is the name Y^^OY, which may possibly be a genuine artist's signature.

One or two other gems signed by Dioskourides have a pedigrce reaching sufficiently far back to, at least, diminish the chance of either the engraved figure or the name being a forgery.

The celcbrated portrait on an ametly'st of Maecenas (or Solon as it has been called) in the Paris Bibliothique, No. 2077 , was known as far back as 1605 .

It is a very nobly cut head, with the name $\triangle 1 O C K O Y P I \triangle O Y$ placed vertically behind it: see Chabouillet's Catalogzt, p. 269.

Furtwängler, however, doubts whether this gem is the identical one which was known in 1605 , and suspects it of beins modern.

In the Marlborough collection there is a very fine frontfaced standing figure of Mercury wearing the chlamys and petasus, cut on an orange serel, with the signature $\triangle$ lOCKOYPI. $\triangle O Y$ in rather large but lightly cut letters. This gem was described in 1599 by Montjosieu in his Gallus Romat Hospes.

It is also mentioned by Spon as having previously belonged to Fulvio Orsini, the well known Roman archaeologist. The design on this gem is obviously copied from a statue not minlike the so called Phocion of the Vatican.

It has, as Dr Story-Maskelyne remarks in his Catalogte of the Marlborough gims, No. 167, been unfortunately ruined by repolishing the 'field.' A copy by Pichler is in the British Muscum, No. 2299.

Another gem which was once in Fulvio Orsini's collection, 
Ifollsnios.

Prockine. nilis.

Carlisle Hirewy. and was described in 15.89 by Montjosieu (op. cit.) is signed by Apollonios AחO $\wedge \Omega$ NIOY. It is a very beautiful figure of Artemis standing, in profile, wearing a short chiton and resting her hand on a ciffus. It is evidently copied from a very fine marble statue of Praxitelean type. Köhler supposes it to be from the colossal $\Lambda$ rtemis of Anticyra by Praxiteles, but the coin reaces of Anticyra, which probably show this statue, represent a figure of different design; see Gardner and Imhoof-Blumer, Numismatic Commontary on Pausanias, Plate $Y$, No. xvir. and page I 24.

Another gem, the design on which is evidently copied from a statue, bears the signature of Dioshourides. It is a very fine sard with a standing figure of Mercury wearing a chlamys, seen in profile, except the head which is turned to the front. In one hand Nercury holds a dish containing a ram's head, and in the other a caduceus. Bchind, in small letters, placed vertically, is the name $\triangle I O C K O Y P I \triangle O Y$.

This gem was for long in Lord Carlisle's collection; but has, in the present year 1890 , been purchased, with the rest of the Carlisle gems, by the British Museum. Neither the engraving nor the signature have a very genuine look; it is a suspicious circumstance that it once belonged to Baron Stosch, to whom the production of many forgerics is due.

The same design, but without the questionable signature, occurs on another gem in the British Museum, No. 705 in Mr Smith's Catalogu, which may possibly be a genuine antique in spite of the unusual material it is engraved upon, a soft stone of an opaque green colour. The Carlisle gem may perhaps be a copy of this, exccuted (with the addition of Dioskourides' name) for Baron Stosch; it is cut on a brilliant sard of fine golden tint, a kind of stone which was frequently used by the engravers of the last century for their best works. However, even if the Carlisle Mercury be a modern production, it is certainly a very beautiful gem and is the work of a most skilful artist.

Among the other sems which bear the name of Dioskourides the most genuine appears to be one which was found in 1756 on the estate of the Duke of Bracciano near Rome. 
It is a sard engraved with a beautiful full-faced head of a female with long flowing ringlets and small horns over the Dioskon riblis. forehead-possibly representing Io. The signature $\Delta l O C$ KOYPI $\triangle O Y$ is cut icrtically in microscopic characters, in the ficld at the side of the head: see Jahrouch A roh. Inst. I 88 s, p. 222 and Plate $S$, No. 25.

The British Muscum posscsses two gems of very minutc workmanship with a similar front-faced head of Julius Cacsar, one from the Riccardi collection on sard, and another on jacinth from the Blacas collection. Both have what professes to be the signature of Jioskourides.

The Blacas gem is certainly a modern work: the modelling of the face is cxaggerated and too minute in style, and the name is wrongly spelt in two places $\triangle I O C K O P I O O \Sigma$ and has the square sigma $\Sigma$ instead of the rounded form $C$ used by. Dioskourides. On the Riccardi gem the name is cut in the

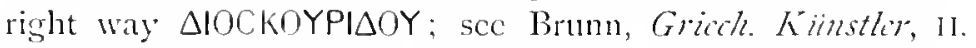
p. 497 ; Fahrouch Arch. Inst. 1888, p. 301 , and Plate II., Nos. 13 and 14 ; and Brit. Hus. Cat. Nos. 1557 and $1558^{1}$.

In addition to those already mentioned the following are among the most important gems with artists' signatures, but they are not in all cases free from suspicion.

Pamphilos; on an amethyst in the l'aris Bibliotheque cngraved with a seated figure of Achilles playing on a lyre, with his arms placed around him, very pictorial in style.

$B y$ the lyre is cut vertically the name ПАMФINOY; sec Chabouillct, Catalogzi, No. I815, p. 243.

A slightly modificd replica of this, with the same inscription is in the Devonshire collection; and another, probably a copy of the Paris gem, is in the British Museum (No. 2305). This copy has been engraved on a genuine ancient gem, on the back of which is cut the sacred Gnostic word IAW.

1 Another artist called lioskourides from Samos, and of about the same date, was a worker in mosaic.

A very minutcly executed theatrical scene, with musicians playing and Iancing, worked in glass tesserae was found in Pompeii, with the inscription $\triangle I O \Sigma K O Y P I \triangle H \Sigma$ $\Sigma A M I O \Sigma$ ETOIHEE at the top of the pictuse: see Rial Hhuseo Burbonico, Vol. Iv. 1827 , Plate 34 . It in now in the Muscum at Naples.

Povratis of Fuliers Catiser. 
Pam. phitos.

$4 \mathrm{gall}-$ opus.

Onesas.

Philimen.

The l'aris amethyst was given to Louis XIV. by I'rofessor Fesch of Basle, so it cannot be a quite modern forgery. It is possible that the inscription meant that the design was copied from a painting by the famous Greek artist Pamphilus, as is suggested by its picture-like style.

Agrathopus; a fine boryl or aquamarine in the Fiorence collection (Uffizi gallery) is cngraved with a very noble head of a Roman, supposed to be Sextus Pompey, in the style of the best Greck iconic heads, such as those on the tetradrachms of Eumencs of Pergamus. Behind the head, in two horizontal lines, is the signature AГАӨOПOYC EПOEI.

This magnificent gem was known in the I oth century, and in 1707 it was published by Maffei in his Gemme Antiche: it is said to have been found ncar Rome, set in a massive gold ring. The British Museum possesses a reflica or copy on sald of this portrait, with the signature and in addition the letter L, which is supposed to be a mark of its having once belonged to Lorcnzo the Magnificent; there is hardly sufficient space in the field for Lorenzo's usual mark, LAVT. MEU. See Musum Flurentimum, Vol. II. I'l. I., fig. 2; and Prat. Mus. Cot., No. 1552: cf. also Köhler and Stephani, Gesammelte Schriften, I $850-3$, p. 338 .

Onesas; in the Florentine collection is a very fine laureated head of the youthful Herakles on surt, with the lion's skin over his shoulder: the upper part of the head is broken away. In a horizontal line is the signature ONHCAC.

The hypercritical Köhler calls this a modern gem, but it has all the appearance of being genuine.

As much cannot be said of another gem in the IFlorentine muscum with the inscription ONHCAC EROIEl, a standing figure of a Muse playing on a lyre, on paste.

Its wide margin and general style suggest that it is a work of some early Renaissance artist

It was known in the $17^{\text {th }}$ century, and cannot therefore be a quite modem forgery.

Philemon; in the Vienna collection is a fine sardenper gem engraved with a nucle figure of a hero with a club, standing in front of an archway, in which the corpse of 
the Minotaur is lying, representing Theseus at the door of the Cretan labyrinth.

Behind Theseus is cut, in a vertical line, the inscription

Philimon. ФIAHMONOC.

Both Köhler and Stephani consider this a modern gem, not without reason: it is very pictorial in style.

A paste in the Strozzi collection with the head of an ivywreathed Faun has the inscription $\phi \mid A H M \Omega N \in \Pi O I[E]]$, but this also is of doubtful genuineness.

Anteros; another gem, about the authenticity of which very different opinions have been expressed, is an aquamarine in the Devonshire collection, with, in the crogre, the inscription ANTEPWTOC.

The design represents Herakles staggering under the weight of the slain Marathonian bull.

It is a very noble and beautiful work, certainly not of quite modern date, but most probably copicd from some ancient terra cotta or marble relief by one of the ablest gem engravers of the i6th century.

The same name occurs on the fragment of a very beatiful ony.r cameo now in the British Muscum, among the Carlisle collection. This fragment consists only of the upper part of a subject which may possibly have been the Judgment of Paris. Little more remains than the head of Paris wearing a Phrygian cap and holding a veil away from his face in a very. feminine manner, and, on the other side, the head of a female figure. The top of the camco is occupied by the overhanging branches of a tree, from which a quiver is suspended. At the right hand side is the inscription in minute incised letters ANTE...EГ ... probably for ANTEP $\Omega$ C EПOIEl.

The comparatively small portion which is, unfortunately, all that now exists of this remarkable cameo is of extraordinarily beautiful and minute workmanship, and the signature appears to be perfectly genuine.

Tcukros; of rather similar style, and possibly of the same

Anleros.

Camialyy Anteres.

Teukres. date as the Herakles and the bull, is an amothyst in the Florentine collection with Omphale (or lole) standing in front of Herakles who is seated on a rock. 
The name TEYKPOY is cut vertically in very minute characters, quite unlike the bold style in which an owner's name was usually engraved on a signet. A great many copies of this or a similar design exist. The sensuous softness of the modelling of the nude forms is more like the production of an artist of the Renaissance perind than that of an ancient engraver, even of the late Greck or Gracco-Roman school.

Though they can hardly be accepted as genuine, the two last mentioned gems are among the most skilful examples of the glyptic art that any age has ever produced.

Moreover they are not slavish copies, but bear the impress of real original power on the part of their engravers.

Aulus. Aulus; probably no other artist s name, real or forged, occurs on gems as frequently as the name of Aulus. It is introduced on a large number of the Poniatowski forgeries, e.g. on one in the Fitzwilliam collection, see page xxv, No. I I.

In many cases the name is clearly that of the owner, not of the engraver, as for example, on a magnificent fragment of a sard in the British Museum with a head of Asklepios. In front of it, on a tablet, is the name AY NOY in large characters'. In fact, putting aside those gems on which the name is a forgery, and those on which it stands for the owner, it is very doubtful whether any would be left to prove that there was a gem-engraver named Aulus.

Hillen. Hellen; the name EAMHN or E$\triangle \wedge \mathrm{HNOC}$ occurs on various gems of doubtful authenticity. Mr King has suggested that this is one of the way's in which the celebrated gem-engraver Il Greco. Alessandro Cesati, known as il Greco, used to sign his works. Alessandro was by birth a Cypriote and was one of the most famous gem-cutters of the I6th century; see below, page 127.

It is also probable that the inscription ANEEAN $\triangle P O C$ or $A \wedge E \Sigma A$ more or less contracted are other forms of the same artist's signature. So also, perhaps, the name KOINTOz $A \wedge E \equiv A$, Quintus Alexander.

For example an onj:r cameo in the Florentine museum

I This is the view taken by Stephani; Gesam. Schrift. III. p. 342; hut Kohler in his usual fashion rejects the gem alogether, quite without reason; see il. p. Ify). 
with a lion, Cupid and two female figures, signed ANEEAND. E, Cesati. is known to have becn engraved by Cesati. It is probably' the cameo mentioned by Vasari as one of Alessandro Cesati's finest works.

In any case there is no real reason for including cither of the last two names among those which can fairly be assumed to be signatures of artists.

Epitynchame; this name, which occurs on screral important gems, may possibly be a genuine artist's signature, at least in some cases. Gems so inscribed are mostly portrait-hcads, such as Marcellus and Germanicus. A very beautiful sardonjer cameo in the British Muscum with a head of a youthful Roman, supposed to be Germanicus (No. I589), has the incised inseription EחITYГXA.

No. 1575 in the same collection is a fune amcthyst intaglio with a front face of a Roman lady, supposed to be Livia, the wife of Augustus, in the character of Ceres. In the ficld is the contracted name EПIT.

What is possibly the same name, contracted to EПI, occurs on a fine camelizn in the Paris Bibliotheque, cngraved with a figure of Bellerophon mounted on Pegasus. As possessing an artist's signature this gem is very doubtful, but the device itself appears to be genuinc, and the gem had becn known for a long time before IS54 when it passed into the l'aris collection ${ }^{1}$.

1 See M. Ilase's Estition of Léon Fiacre, pullished in Paris in 1819. 


\section{CHAPTER VII.}

\section{InSCRIPTIONS ON GEMS (continued).}

Sisnich canicos.

Camio of Allinion.

Piste?

cameo.

CAMEOS WITI ARTISTS' NAMES: in judging of these, if the name, like the rest of the design, is in relief we have the advantage of knowing that it must have been cut by the original engraver of the whole design, and cannot have been added by a later hand; so we are at least spared the double difficulty of deciding first whether the gem itself is genuine, and secondly whether the name may not be a subsequent addition by some forger.

In many cases the signatures on cameos are not in relief, but are incised, like the name on an intaglio; all such signatures must be regarded with some suspicion.

Among the most authentic signed cameos is a large sardony $x$ in the Museum at Naples, with Zeus holding a thunderbolt and driving a quadriga over the prostrate forms of the conquered earth-born Giants. In the exergue is the name $A \Theta H N I \Omega N$ in relief, in minute letters. The whole design is clearly the work of a talented artist of the Augustan period; and even the sceptical Kohler throws no doubt upon its genuineness. That the name Athonion is that of the engraver rather than of the owner of the cameo is suggested by the minuteness of the characters. Moreover an owner's name, which was a natural addition to an intaglio-signet, would certainly be a less frequent addition in the case of cameo gems. The same name (Athenion) occurs also on a large fragment of a cameo in bluc paste in.the Berlin collection, with a standing figure of a Roman General, supposed to be Drusus the elder, in a triumphal quadriga. The name 
$A \Theta H N I \Omega N$, in exactly similar letters to those on the Naples cameo, is placed in the crover of the Burlin paste, which is, no doubt, an ancient copy of a worle of the same engraver who cut the Destruction of the Titans by the thunderbolts of Zeus.

In the Florentine collection there is a very good cameo in sartonyt with Cupid riding on a lion and playing a lyre. in the cirmo is the signature in relief MPSTAPXOS EПOEI, which even Kohler admits to be genuine, placing it among the five examples of signed gems which are the only ones he accepts ats ancient gem signatures.

Another very fine signed cameo was in the collection of Lord Beverley, and is now in the possession of the Dule Camio of birehos. of Northumberland at Alnwick Castle. It is a sardony with a nude figure of Pliloctetes in Lemnos, seated on the ground: in his right hand he holds a bird's wing, using it to fan his wounded foot, which is bound round with bandages.

In the upper part of the field is the name bocthos, BOHOOY, cut in relief.

The design of this cameo is very slitfully contrived to fill up the surface of the gem in the most complete way, and tie details are cut with great minuteness and naturalistic truth, especially noticcable in the head and in the modelling of the chest and ribs.

In spite of Stephani's opinion to the contrary, this cameo bears all the marks of being a genuine antique work of the Augustan agge: see Amali lust. 1881, p. 266.

Mr King has howerer suggested that the name Bothos is not that of the engraver of the camco, but that the gem was copied from an embossed relief in silver by the celebrated sculptor and caclator named bocthos, who is mentioned by Pliny (Hist. Nat. Xxilu. 155) as being onc of the principal Greck workers in the precious metals, and (H. N. Xxxiv. 84 ) as being the sculptor of the boy strugsling with a goose, of which ancient replicas are now in the Vatican Museum and elsewhere. However this may be, the motive of this cameo is an carly one.

It occurs on an intagrio of the scarab type, within a cable 
border, in the British Museum; see Brit. Mus. Cat. No. 455 ; and Amali Inst. I 857 , Pl. H., fig. $6^{\prime}$.

Incisial name's.

Minkonrid's.

Cillini. Benvenuto Cellini, hib. 1. cap. 27. Cellini tells us that during his first stay in Rome (from 1524 to 1527) he was in the habit of buying from the peasants large numbers of ancient gems, which they found while digging in the vineyards in and around Rome. Among these was the cmorald with the cholphin's head, mentioned below at page 135 , and a marnificent head of Minerva on a large topas. The finest of them all was, Cellini says, a cameo with figures of Hercules subduing Cerberus, which he showed to Michelangelo, who remarked that it was the most wonderful piece of work he had ever seen.

It is not impossible that the canco described by Cellini is the one now in the Berlin collection ${ }^{3}$.

1 both the cameo and the British Musem intaglio are described by Milani, Mito di Filotete, p. S6, and I'l. 11.

In his Gisth. der Grich. Kunstler, 1859, Vul. 1I. Dr linum liscusses and molities the conclusions arrived at by Kohler and sicphani, Gesmmelte Sithriften, Is, 50-3, in which work alnugt all gem signatures are taken to be forgeries.

3 It necel harelly be sait that kinler refises lo aceept this grem as a genuine 
In the Museum at Naples there is a very fone setrilong. cameo engraved with a figure of Victory driving a ligg, over which is incised the inscription C CCTPATOY. The gem once belonged to Lorenzo de' Medici and has LAVk, MEU. engraved under the horses of the biga.

Among the gems of the Carlisle collection, recently purchased for the British Museum, is a fine onyx canco with Cupid leading a chariot drawn by two panthers. In the

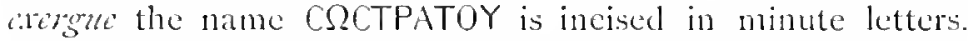
The same nane occurs on a small, delicatcly cut intaglio in the same collection, with a figure of a winged Vietory sacrificing a bull, on which she rests one linee. The name

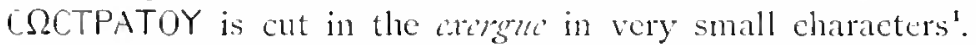
Both these appear to be unduubtedly genuine examples of an artist's signature.

If the truth could be known it would probably be found that a large proportion of so-called artists' signatures on gems of all sorts really are names of owners, more especially in the case of signet gems, intaylius. Artists were much more likely to introduce their own names on cameos for the reasons which are inclicated at pages $92-93$.

If however the same name is found to be repeated on several gems of similar date and style, as is the case with the above-mentioned name Sostratos, we may fairly assume that it is the grenuinc signature of an engraver.

Gem signatures, unlike artists' names on coins, are rarely cut on part of the cingraved device; usually they are placed in the field. There are however onc or two possible exceptions to this rule, as, for example, the full faced head of the dog Sirius, with a collar round his neck. Several replicas and copies of this exist ${ }^{2}$ : one of the finest is No. 270 in the Marlborough collection, engraved on a very beautiful oriental carbuncle: it has $\Gamma$ AlOC EMOIEI on the collar ${ }^{3}$.

anligue: in fac he denies the authenticity of all the signatures of Diosliourides: see Gesamm. Schrift. In. D. 287 .

1 This gem is published by Tassic, l'late xiv. No. 7560.

- One in the Ierlin Museum, cut on rock orystal hy Lorenzo Massini for Laron Stonch, has the molern signature MACINOC (Mavini) ETOIEI.

"The signature on the sirius gem in the Marlborough collection, and even 
The two similar gems in the British Museum, from the Payne Knight and the Blacas collections (Nos. III5 and I I I6), are without the signature.

A very beautiful and large chalcelony gem in the British () natas.

Dates of sems.

Gim of Sjrias. Nuseum (Brit. Mlus. Cat. No. I $16 \mathbf{1}$ ), engraved with a figure of Victory erecting a trophy, a somewhat similar design to that on a Syracusan tetradrachm of Agathocles, has, on the ribbon-like folds of a long flag attached to a spear, in characters of somewhat indistinct form, what is possibly the

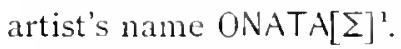

The genuineness of this noble gem has been questioned, but Furtwängler and other good authorities accept it as a genuine Greek work of the early part of the 4 th century B.C.

With regard to the dates when engraved gems most frequently received the signature of the artist, it may be remarked that this was very rarely done before the $4^{\text {th }}$ century i.c. In fact signed gems were very exceptional throughout the whole of the autonomous Greek pericd; by far the majority of those which now exist are the work of Greek engravers during the time of the Roman Empire, especially the Augustan period.

There is however in the British Muscum (No. 479 in $\mathrm{Mr}$ A. H. Smith's Catulogze') one very remarkable signed gem which apparently is not later than the middle or latter part of the Gile century b.C.

It is one of those curious scarabaeoids which have on the curvel back a design carved in delicate relief - in this case a Satyr's head-the carliest form of cameo, mentioned above at page 59.

The device sunk on the flat or signet side of the scarabaeoid is a standing figure of a bearded harp-player, and round the edge of the field is the inscription which $\mathrm{Mr} \mathrm{A}$. H. Smith, gives as SVPIAS EITOIESR ${ }^{2}$.

the gem itself is by no means above the suspicion of being the work of Natter, the name is probably a blunder for TNAIOC.

${ }^{1}$ Furtwangler is inclined to read the inscription ONAIA; see $F$ almath Arth. Inst. i 888, p. 204.

- Others react the name of the artist, not as Suras, but as Duries, $\triangle O P I E S$ : see Furtwangler, Furhech Arch. Inst. 1888, p. 1y6, and I'l. 8, No. 1. 
This is a quite exceptional gem: almost no others occu with an artist's signature till the th $^{\text {th century I.C., to which }}$ period the various signed gems found at Kertch evidently belong; see page 73 .

In the case of Greek coins, artists' signatures were not uncommon during the latter part of the 5 th century P.C., but

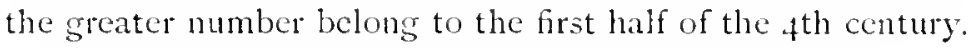

On Roman coins artists' signatures are unknown.

On Greck a'ases painters' names were most common during the 6 th and 5 th centuries D.C., and till about the middle of the $4^{\text {th }}$ century.

After the time of Alexander artists' names on pottery soon totally disappear.

\section{Antists' Names on Colns.}

As some guide to forming a judgment with regard to signatures on gems it may be well to consider the somewhat analogous case of coins which bear the artist's signature.

With very few cxceptions, the coins on which artists' names occur are those of Sicily and Masna Graecia during the 5 th and $4^{\text {th }}$ centuries L.C., especially coins of Syracuse, Catana, Metapontum, Tarentum, Heraklaca, Velia, Thurium, Camarina and a few others. The great decadrachms of Syracuse, signed by Kimon and Euainctos, are among the chief glories of numismatic art.

The name is usually in the nominative, the word EMOIEI being understood, though in some cases the genitive is used, as if before EPTON; and it is cut in very small characterssometimes of microscopic minuteness. As a rule the artist inserts it in a way that makes it as little conspicuous as possible, so as not to rival the importance of the type legent. For this reason it is frequently introduced on some detail of the design; thus, for example, Kimon signs on a dolphin under the main head on the oborse, or on the band which binds the hair of Persephone. 
Euklitus. The name EYKAEI $\triangle A \Sigma$ occurs among the ornaments of Athene's helmet on a Syracusan tetradrachm: and in many other cises the signature escapes all but the most minute examination. In some examples the name is more conspicuous, though cut in microscopic characters, as on some Syracusan reverses, which have a tablet inscribed EYAINETO held by a flying Victory - possibly a sort of pattern or trialpiece by this wonderful cugraver.

Mr tistans on sirnted coins.

$\mathrm{Mr}$ A. J. Evans, in his Horsomon of Torontum, is8S, pase 120 , was the first to point out that, very frequently, when a coin has the same name repeated twice, the signature in the one case was, probably, introduced as that of the engraver of the coin-dic, and, in the other case, as that of the same person, not in his quality of artist, but as the форуироко́тоs, or actual striker of the coin, as a guarantee for its being of the repuisite weight and purity of metal.

This very ingenious suggestion satisfactorily explains what was previously a very puzzling problem. It may yet be possible to discover some definite reason for these names being sometimes in the nominative and sonctimes in the possessive case.

On many coins the artist's name is not griven in full, as it usually is on gems, but in a contracted form or with an initial only. As Mr Evans has pointed out, the same coinengraver seems often to have worked for more than one city; coins of different colonies both in Magna Graecia and Sicily occurring with the same signature.

A very interesting paper on the signed coins of Sicily and Magna Graecia was recently read by Mr Evans before the Numismatic Socicty in London, and will shortly be printed in the Num. Chron., Vol. for 1890 . Several examples of hitherto unpublished coins with artists' names, in the possession of the writer, were described in this paper; among them were the following-a tetratrachm of Himera with the usual raterse, the nymph Himcra sacrificing at an altar; on the cornice of the altar, in letters of microscopic minuteness, is the signature KIMON. The remarkable thing about this unique coin is that its style shows it to be not later 
than about 470 to 465 I.C., and therefore it supplies an example of a signed coin nearly half a century carlice than any which had previously been known.

The artist who signs himself KIMON may possibly be the grandfather of the later KIMSN, whose name occurs on at dolphin under the head of Persephone on one of the celebrated Syracusan decadrachms which were struck towards the close of the 5 th century, and also on other coins of the same city.

Another signed coin, hitherto unpublished, was a Syracusan tetradrachm with the artist's name EYAPXI $\triangle A \Sigma$, il dicengraver who worked in conjunction with the Syracusan Plingisillos, who is mentioned below.

A new signature of EEAKE $\Sigma T I \triangle A \Sigma$ occurs on al tetradrachm of Kamarina, not cut on the exosurl line, but on

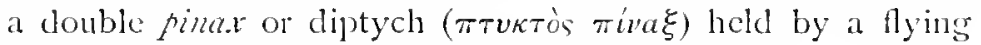
Nike over the victorious quadriga on the rearse.

As a commentary on the grem-like style of the coins of

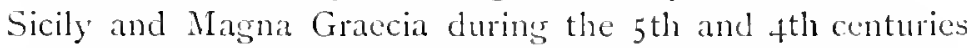
13.C., it is worth while to notice that one very beautiful gem, with a seated figure of Eros playing with astragerli, has an apparently authentic artist's signature $\Phi P Y \Gamma \mid \triangle \wedge O \Sigma$; and that the same artist's name occurs on scveral very beautiful coins, as, for cxample, on the obirse of a Syracusan tetradrachm of a little before 400 13.C. with a head of I'ersephone. The races type, a quadriga, has the signature of another artist,

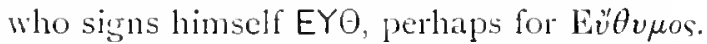

It is quite possible that the grem with the figure of Eros may be the work of the same J'hrygillos who engraved the Syracusan coin obicrse; Raoul Rochette and (more recently) Furtwingler and Mr A. J. Evans have accepted this theory-1.

The very few artists' names that occur on coins outside of Sicily and Magna Graccia are sometimes treated in a different

I See Furtwängler's G'mmen mit Kinstlerinschificn, "Guthbuch dis Lits. Diats. Instit." 1888 , Bant ir. p. 197. I'I. 8 , No. + . I have not been able to ascertain who is now the possessor of the Eros.of Phrygillos.

On Sicilian coins with artists names, sec Rudolf Weil, Dic Kanshirinschrifin de' Sizalischen . Minsin; Berlin, $18 s_{4}$. 
way, being cut in larger, more conspicuous characters, and having, in two cases, the word EПOEI (sic) after them.

Thioktus.

A beatiful tetradrachm of Clazomene in Ionia (near Smyrna) has a full-faced head of Apollo on the obarese, and by it, in the field, in two straight lines, the signature

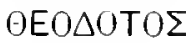 EחOEI.}

The position of the head on the die is arranged so as to give ample room for this inscription, which is by no means hidden away, like most of the former class of signatures.

Kanasos. A similar inscription occurs on a much less beautiful tetradrachm of Cydonia in Crete, which has on the olaterse a profile head of Ariadne, and in the field the signature NEYANTOS ETOEI.

Both these remarkable coins are of about the middle of the fth century li.e.

1ytho. A third Cretan coin, of the city of Aptera, near Cydonia, has the signature $\Gamma Y \Theta O \triangle \Omega[P O \Sigma]$ in large letters, but without the word éroiel, which only occurs on the two last mentioned coins.

Coins struck in the mainland of Greece very rarely bear an artist's signature. The most notable examples are the fine silver statios issued about the middle of the 4 th century coins of 1.C. by the Arcadian Federation. On the obrerse is a noble Aradiu. head of Zeus Lycacos, and, on the rearss, a figure of Pan seated on a rock, with the fidum or shepherd's crook in his hand. On the rock, in minute characters, is the engraver's signature OAYM. or more rarely XAPI.; see Head, Hist. $N m m$. pasge 373 .

Signcl It may at first seem strange that artists' names should be so rare on gems and coins, and so common upon Greek vases - which belong to an inferior grade in the rank of the lesser arts. The reason is probably this, the coin-type was a thing of public importance and had a distinctly sacred character, so it may usually have been thought presumptuous for an artist to introduce his name in such a place'. Again,

1 The sacret character of the types on coins was the reasun why portraits of 
the gem was meant for personal use as a signet, and most men probably would have objected to another name than their own being set on their seals; unless the engraver were an artist of such fame that his signature materially added to the value of the gem, as appears to have sometimes been the case in the Roman Imperial period. With painted pottery the case was different: a maker's or painter's name could offend nobody, and was proportionally, of quite insignificant size. in no way interfering with the painted pictures on the vase. If however the gem were large and not intended for use as a signet, such as the Julia of Eudos, or still more if it were a cameo, there would be less reason to object to an artist's name being inscribed upon it.

In all cases where the name on a gem is cut in large letters, and is in the senitive, it may (if not a modern atdition) be considered to be the name of the owner. Owners" names in the nominative also occur. but not usually in minute characters such as engravers used. A certain number of gems exist which have the name of some distinguished sculptor, such as Phicilias or Scopas: in most cases these are obviously modern forgeries, but there may possibly be some antique Roman examples in which a gem has a copy of some piece of sculpture together with the name, not of the engraver of the gem, but of the sculptor of the original statue.

3. EXIAANATORY WORDS: on many Oriental cylinders, in addition to the owner's name, an inscription explains who are the gods or heroes engraved upon it.

So also Greek scarabs and scarabaeoids of the 6th and 5 th century B.C. have in some cases names cut by the side of the figures on them to explain the subject, a very common practice on the painted vases of the same period.

This is specially the case with the scarabs found in Etruscan tombs, both those which are imports of Hellenic workmanship and those which are native Etruscan imitations of Greck designs; see above, page I4.

Again, on Graeco-Roman and Roman gems which re-

living persons were not introduced till comparatively late times, after the death uf Alexander the Great. 
present some god or goddess the inscribed name of the deity is frequently added.

II ordis of arplanation.

This was spccially nccessary with the crowd of deified abstractions which appear so often on coins and gems of the Empire; since in many cases it would be impossible to know what subject was intended without a word of explanation, such as Concontia, Munificentia, Felicitas, Indulgontia, or the like, the symbols and attributes used by the Roman artists being not sufficiently numerous and varied to indicate, without ambiguity, so large a collection of abstractions.

On the finest gems both of the Greck and the GraccoRoman period inscriptions of this class rarely occur-the dcricc bcing intended to tell its own story, and the artist having sufficient skill to do so in a sufficiently intelligible manner.

4. TALISALANIC INSCRIPTIONS occur frequently on the later Roman gems used by the Mithraic, Gnostic and other mystic sects. The magical word Abroras', and the names of the three Gnostic Acons, IA , CONOMON, CABA $\Omega$ are of specially common occurrence.

A great number of other mysterious combinations of letters were cut on these talismanic stoncs. The Paris Bibliothèque contains a large and varied collection; see Chabouillet's Certalogute, p. 282 seq. ${ }^{2}$

A profession of the Divine Unity (like that of a modern Moslem) is of frequent occurrence on sems of the second century A.D. - EIC OEOC CAPAПIC, and other similar phrases: see Nos. 20 and 105, Fitawilliam Catalogue.

In several places (H. $N$. xxxvil. 12+ \&c.) Pliny expresses his contempt for the superstitious belief in the magical power of gems, but nevertheless these mystic devices were very popular under the late Empire, especially when one of the favourite Roman cults arose out of a combination of the

1 'The meaning of the word Abraxas is explained in the Appendix; Cat. of Fits. Gims, No. 20.

2 For information on this curious subject see Natter, Histoire du gnosticism, Paris, 1850; and C. IV. King, The Gnostics and thit rimains, and al. Londen, $188 \%$. 
Gnostic philosophy of Alexandria with the mystical Mithraic worship of l'crsia.

5. WORIS OF GREETING and the lilit: these are common on gems of the Roman Imperial perind, usually written in Greek: as, for cxample, XAIPE, EYTYXI, MNHMONEYE (sec No. IIo, Fits. Cort.), ФIAEI ME, ZHCAIC MOMAOIC ETECIN and the like.

A curious onyx camco in the Marlborough collection (No. 643) appears to have been a love gift from a laty. It is engraved with a hand pinching an ear and the inscription

\section{MNHMONEYE MOY THC KANHC YYXHC \\ EYTYXI CWDPONI}

"Remember me, your pretty love.

Good luck to you, Sophronios."

Inscriptions such as this are frequently cut in camco, and occupy the whole field of the stone: they usually have the letters cut in relief in the white stratum of an ony't on a dark ground.

Proscrbial flerases sometimes occur on late Roman rems; Provere. the following l'hilosophical maxim is specially common-

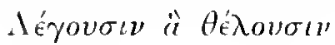

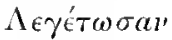

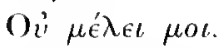

A free translation of this phrase is inscribed over the doors of various houses in Scotland, built in the Ifth and I 7 th centuries;

\section{Then baif saíx. \\ Quubat san then! \\ Ilat thame sall.}

An cxample in the Paris Bibliotheque has the following addition at the end of this phrase

\section{CYФINEME \\ CYMФEPICOI}

meaning "Love me: it is for your advantage (to rlo so)." 
6. DEICATORY INSCRIPTIONS on gems are rare. An example is in the Marlborough collection, No. 256-a very large nicolo, with Astarte on a lion and the Dioscuri. In the

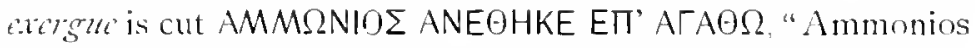
dedicated this for a blessing." It is a gen of the late Empire, probably of North African workmanship.

A sortony cameo of the Roman Imperial period, with a male and female portrait head facing each other, in the l Termitage Nluscum at St Petersburg, has, between the two faces, the names A $\$ H O C$ CYN APHOWNI, in incised letters. This is probably a rotive inscription, the cameo having been dedicated in some temple, perhaps by a husband and wife'.

In the middle ages this gem was prescrved in the treasury of the Abbey of St Germain-des-I'rés, where it was revered as having been the betrothal ring of St Joseph and the Virgin Mary; it is worn smooth with the kisses of thousands of pilgrims.

When the Abbey was sacked, during the French Revolution, this venerated cameo was carried off and sold to a Russian Gencral, who presented it to the collection of the Emperor of Russia.

1 Some archaeologists explain this inscription as being the signature of two joint gem-engravers, lut the inscription seems to be later than the cameo itself, and is larger and more con ppicuous than is usually the ease with artits' signaturec on gems. 


\section{CHAPTER VIII.}

\section{THe CHARlCTERIstics of ANCIENT Glis.}

Fine Greck or Graeco-Roman cngraved gems are among the most beatiful works of art that exist. They combine noble design and exquisite, but not too minute, finish with the sreatest beauty of material, such as the rich, brilliantly coloured sard or the safflinine chalictony with its exquisitely soft, milky lustre.

The more brilliant varieties of serd glow with a sort of internal lustre when held up to the light, and the device engraved upon them comes out at once soft in effect, and clear in outline, with a sort of beauty which hardly can be rivalled in any other branch of art.

Small as gems are in scale, the Greck artist possessed the rare secret of giving grandeur of effect without the aid of sreat size; and some of the most minute gem engravings secm to have all the dignity of a large group or bust in marble or bronze'.

As a rule the sencral design or composition of an antique gem is very skilfully contrived to occupy as fully as possible the "field" or flat surface of the stone, leaving the least possible quantity of empty margin. In the gems of the 6 th century B.C. this principle is sometimes carricd almost too far, and the figures are occasionally bent into somewhat strained

1 This grandeur of effect produced ly work on the smalkent scale is well exemplified by the wonterful "Siris bronzes" in the British Museum, and by the still more beautiful heroic figure from the Lago di bracciano, which is e whilited in the

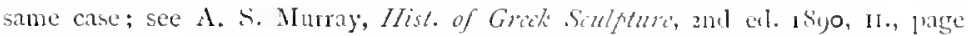
$34^{6}$, where the latter statuette is illustrated under the title "lironze from Tarentum." 
attitudes in order to bring them within and yet close up to the curved limits of the "field." An example of this is illustrated in fig. I6 at page 25 .

Siriliul comfosi. tion.

Borders

Moldin style.

homin style.
But in the best work of the 5 th and $4^{\text {th }}$ centuries B.C. the highest amount of skill and taste is shown in designing the composition so as to fall casily and gracefully within the necessary limits ${ }^{1}$ : see fig. I7 at page 26. Thus we find that in the best chass of gems with a guilloche border the most projecting portion of the composition is often allowed to encroach slightly upon the border, thus giving a look of freedom to the whole, and making the border an essential part, not a mere frame, to the design. In the finest gems with a border in the Fitzwilliam collection this is the case: see Nos. 5, 10 and I I on Plate I.

In the carly Greek painted vases of what is called the Oriental styte the same dislike to unoccupied spaces is to be scen-the so-called horror arum, which leads the painter to fill up his ground by a seme pattern of rosettes, crosses and other ornaments.

One of the most obvious differences between antique and modern gems is this absence of margin or unoccupied space in the former class.

Thus the exquisite Diomede with the Palladium from Lorenzo de' Mledici's collection, though in some respects very Greek in style, being copied from an antique, is very unlike an ancient gem in the wide extent of margin all round the figure.

The I'oniatowski forgeries have the same modern peculiarity; see, for cxample, Modem Gems, No. 1 i in the catalogue of the Fitzwilliam gems in the Appendix.

In the case of Roman gems this rule does not apply; the device by no means invariably fills up the whole field. Far less skill and taste are shown in adapting the design to the shape and size of the gem. The same remark may be made with regard to Roman coins, especially the reverses of aurei

${ }^{1}$ In (ireek coin of the lest style we see the same fully occupied fielt, and the same wonderful skill in unting the design lo the space. On koman coins these points are much liss attended to by the dic-cutters. 
and denarii of the Imperial period, with a single standing figure of some deity or deified abstraction, the scale of which is frequently small in comparison to the whole circular field of the coin, leaving a large proportion of unoccupied space on each side of the figure.

Another noticeable point is that, while many molern sems are fictorial in style, those of the ancients are rather of a simlfuresqu character-simple in composition, with very few figures, seldom more than three during the best periods; and the whole design is treated strictly on one plane, like the relief-sculpture of all good artists. The skilful treatment of the "relief' with a certain monotony of surface, avoiding excessive projection, is one of the chief characteristics of grood Greck work.

In gems of the Roman period the 'relief' is often much exaggerated, with an excessire roindness of form, very linlike the flat relief of the 5 th century b.c. In many cases this excessive amount of projection suggests that the design is a copy of some piece of sculpture in the round.

Apart from the details of the treatment, the whole design of some gems of Imperial date shows that the gentengraver has copicd some statue of large scale, regardless of the fact that the design was quite unsuited for reproduction on a minute scale". On finc Greck gems, on the contrary, the design is exactly suited to the very stone it is cut upon, seldom looking like a reduced copy of some larger work, and still less like a reproduction of a statue.

All these rules are however quite useless for distinguishing between ancient and modern gems when the work of a elever forger is in question, a man who has carefully studied and copied the characteristics of genuine antique gems.

The fact is that in no other class of art is it so difficult to distinguish the genuine from the false; partly because age makes no alteration. gives no fotina to a hard polished sem ; and secondly, because, owing to the hardness of the material

1 'Relief' is here used as referring, not to the intaglio itself, but to the implession from it.

2 For examples of this, see page is. 
Cofics of antielue sethls.

Fich ac polishat.

(1)isinal folish.

Tists for

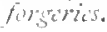

and the laborious method of working it, there is necessarily something mechanical in the process of engraving a gem, which diminishes the prominence of the artist's personal peculiarities and touch.

Noreorer many of the cleverest forgeries are copies of some antique gem or paste, so there is nothing in the design to betray a modern origin. Copies made by the most skilful cngravers of the last century, such as Natter, Pichler and Burch, are often quite indistinguishable from antiques, especially when we remember that a highly polished, freshlooking surface is not always a proof that the gem is modern.

A large number of genuine antique gems have had their flat field repolished in modern times, much, of course, to the injury of the work. This unfortunate habit was specially. prevalent in the I $7 \mathrm{tl}$ and ISth centuries: many of the best gems of the Marlborougl and Devonshire collections have been sadly spoilt by this reckless treatment. And again, many gems, which have rested undisturbed in a tomb, still have their original polish as fresh and brilliant as when the stone was first cut.

The skilful forger is careful to use only such tools as were in use among the ancients, and there are often no means of deciding whether a wheel cut or a drill cavity in a hard gem was made yesterday or more than two thousand years agro.

A great number of different tests have been suggested for the recognition of genuine and forged gems; but the initation of none of these criteria presents any real difficulty to a skilful and intelligent forser. Proofs of antiquity have been said to be these-extensive use of the "diamond-point," complete internal polish of the details of the design; and again internal polish which, though once complete, has been slightly dulled, as if clouded by the human breath.

With a little extrit trouble any modern engraver can polish the whole of his design; and a drawing-stamp with sume diamond or emery powder will readily take off the apparent freshness of the polish, and sive the requisite clouded look to the work. 
A still better method of clouding the original pelish has been recently adopted by the Roman forsers. A shower of Trikls of formess. (liamond dust is blown out of a small tube against the sunk part of the intaglio; a method which was suggested by the "sand-blast" which is sometimes used on a large scale to drill or carve stone for building purposes.

The more obvious signs of age, such as a worn surface, covered with fine scratches, are given to modern gems in many different ways. The most deceptive appearance of lons wear is produced by crammins the newly cut gem down a turkey's throat, and leaving it for a few days to be shaken up with the bits of stone and gravel which are contained in the turkey's craw.

Freshly cut camcos readily take the marks of age, first by the use of the ordinary rubbing and scratching processes, and sccondly by the use of a mixture of iron filings in acid, which rapidly gives to the white layer of an onys the dead, glossless look which is frequently the result of great agse.

Even the fact that a $\mathrm{gcm}$ is seen to be in its orisinal antique ring-setting is no absolute sccurity against fraud. The present writer has seen in the work-shop of a Roman intagliatore a skilful cngraver at work on an antique gem which had been found set in a massive gold signet-ring on the skelcton hand of the occupant of an Etruscan tomb. Without removing the grem from its setting the engraver rapidly drilled out the very slight and shallow original design, and produced another much more imposins interglio, with a very bcautiful head, carefully copied from a Syracusan coin : the subsequent treatment of the gem with emery and diamond powder cntirely removed its obvious look of freshness, and the original setting remained as a false witness to the antiquity of the work.

The result of all this is that in many cases no archacologist, however learned, can attain to real certainty about the age of a gem - a quite trustworthy criterion has yet to be discovered.

Fortunately in most cases imitations of antique gems are not the work of a forger who combines sufficient knowledge 
with the requisite skill, and a careful study of ancient gems will save the student or collector from being deceived by any except forgeries of the most skilful kind.

Gins $r i t$.

Pustruciti.

Cilliea Flind.

St Gorpe ant the (d)

Among the most difficult cases to distinguish are those gems, which, though originally antique, have been partially or wholly re-cut by a modern hand.

In the last century, and cven more recently, this was a very common trick of the ltalian dealers, especially in the case of cameos.

A very large cameo on a magnificent sardon'x, now in the St P'etcrsburg collection, 'was wholly reworked carly in this century by Benvenuto I'istrucci, who (without any fraudulent intention) executed much work of this kind for the Roman dealers, whon he was a young man working in Rome, about the year I Sol. The St Ietersburg cameo represents a Roman Emperor standing and being crowned by a female personification of some city. The gem was originally very late Roman work of the rudest execution. It is now well-cut work, which appears to be of the style of the carly empire.

l'istrucci, who was born in 1784 , was the last of the really distinguished gem-engravers of modern times. He was the artist of the famous camen head of Flora, a work of purcly modern design on a fragmentary onyx, which he exccuted for a small sum for some unscrupulous dealer, who sold it for E500 to l'ayne Kinight as an antique Greek gem ${ }^{1}$. Pistrucci wrote a very interesting autobiograpliy, in which he gives an instructive account of how this and others of his carly gems were passed off by the Roman dcalers as antiques; sce p. I.47 of Dr Billing's Science of Goms, i 867 , in which extracts from this autobiography are published. I'istrucci was employed as a die-cutter in London under Gcorge IV. and William IVt. He is the author of the fine rroup of St George and the dragon which is still used on the English sovereigns and crowns - a very happy contrast to the dies produced by more recent artists.

\footnotetext{
1 l'ayne linight's Late and knowledge are exemplifed by the fact that he tried hart on prevent the purchane for a comparalively trithing stm of the Elgin marlules on the groum that they were inferine works of art, and of lioman hmperial date!
} 


\section{CHAPTER IX.}

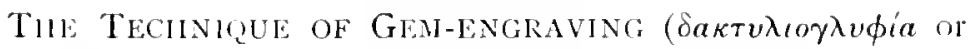
$\lambda_{\iota} \theta$ ou $\left.\rho \gamma \iota \kappa \eta\right)$.

Tile tools used by the ancient gem-engravers were mainly of three different sorts, namely the drill, the alled and the "diamont-point." In using all these the gem itself was firmly fixed in a bed of cement made of pitch and pounded pottery (testere tunsai). The tools were held in the engraver's hand, who thus had a greater freedom of touch than a modern gem-engraver, who usually works in the reverse way, having his drills and wheels fixed, and the gem loose in his hand ${ }^{\text {t. }}$

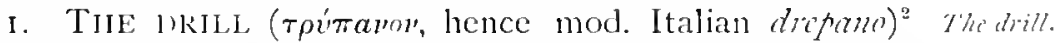
was worked in the old fashion, which still survives in the East: the string of a small bow was wound round the stick of the drill, which was made to revolve by moving the bow rapidly backwards and fotwards. The butt end of the drill revolved inside a cap or tube, which the engraver held in his hand, and so directed the point to the right place; he could not, of course, hold the drill by its revolving part.

It is only long practice that enables a workman to manage successfully the difficult task of carrying on simultaneously a distinct movement with each hand; so in some cases, especially when working larger sculpture, an assistant worked the

I The word $\gamma$ kifew is used by the Greeks for the process of engraving gems: hence the modem phrase "glyptic art." In Latin sculfere has the same metaning, lut it is also used for other processes, such as carving in marlle, cquivalent, that is, to the word sulpin; see lling, H. N. Xxxv1. I5.

"The worl topros (Latin tornus) appears to he used for any revilving toul; thus it means both the drill and the zwhed of the gem-engraver, as well as the lathe' used in many different crafts.

Tow sol sem-chts $\operatorname{lin} i r$. 
bow, leaving the engraver free to direct the point of the drill. This is indicated in some of the reliefs found in Egyptian tombs which represent sculptors at work on statues of porphyry or granite, materials of such hardness that they could only be worked by clills and emery.

Siuplor's A Roman sarcophagus, published by Blimner, Technolegic, will. III. p. 220, has a very intercsting relief showing a sculptor at work on a lion's head which is one of the ornaments on a fluted sarcophagus which he is carving. He holds in his hand a pipe-drill which is made to revolve, not by a bow, but by a cord which a boy assistant is pulling backwards and

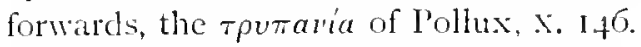

Drill ln ISS9-90 Mr Flinders Petric found in tombs in Upper Egypt several examples of the bows used to work small drills. They are of hard wood, about it inches long, slightly bent, and have near each end a square hole in which the cord was fastened. Exactly similar bows are commonly used eren now for drilling both in the East and elsewhere.

Firim, The word tevimayol also means an instrument used in

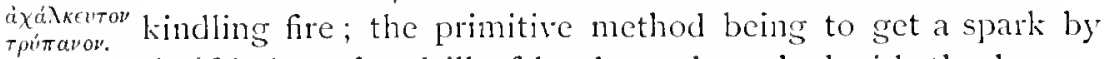
the friction of a drill of hard wood, worked with the bow so as to bore a hole in a piece of softer wood; cf. Soph. Frag. 640.

Many of these "fire-sticks" have been found in Egypt, with rows of drilled holes in them, each charred by the friction of the drill.

The same method of getting fire by friction is still $\mathrm{cm}$ ployed by various savage races, who work the drill both with and without the bow.

In gem-engraving the point of the drill, which cut into the stone, was of soft metal, usually bronze, and varied in size from

that of an ordinary pin to a good-sized knitting needle or even larger. The actual cutting of the drill was done, not by the metal, but by the fine emcry powder ( $\sigma \mu$ ipes, Narimm) which, mixed with oil, was kept constantly smeared upon it. The minute particles of emery, which is a form of commdum, stick in the soft metal under the pressure, and so give a steady cutting surface. If hard steel were used the emery powder would not adhere to the drill, and the cutting would go on much 
slower ${ }^{1}$. Even wood or bone in connection with emery will make an excellent drill. Some of the Iill-tribes of India eren Hoolen now drill quartz-crystal with a picce of bambon and cmery of sand and water, using the bow to make the drill rewloe.

The drill and bow-string were not tools peculiar to the sem-engraver, but were used in all the arts of carring and sculpture from the ship-wright upwards. Drills on a large scale. such as augers for boring planks, were worlied by a cord held by a man at each end, as is described by Homer ( Od. I.i. $382-386)$ in the passage about Odyseus destroying the eyc of Polyphemus. A very interesting gem in the British Muscum (No. 305) a Greek scarab of the 5 th century 1; C., has a well cxecuted figure of a workman (shown in fig. 21), probably a gem-engraver, using the bow-drill on some small object fixcd upon a table.

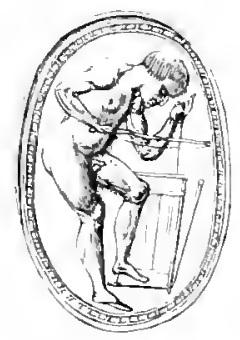

FIG. 2r. Greek scarab of the sth century [.C. showing a man working with the bow and trill: toubli the real sizc.

Pliny (Hist. Nat. Nixvi. 54) speaks of the Naximm, or emery of the island of Naxos, as being the best for cutting and polishing gems ${ }^{2}$.

He gives (Hist. Nat. Xxxiri. 200) an interesting list of the different tools used in gem-engraving. Speaking of the varying hardness of stones, he say's, "tanta differentia est ut aliac fcrro scalpi non possint, aliae non nisi retunso, ommes

1 It is for this reason that molern diamond-cutters nse, not a steel, but a copper wheel for forming the faccts when they are cutting a brilliant, rose- or 1.2lue-diamonel.

a The Naxian emery at the present day afforls to the Circek grovinment a revemue of more than $\mathcal{L}, 0,000$ a year. 
autem adamante: plurimum rero in is tercbrarum proficit fervor."

His meaning appears to be this-"only the softest signetstones (such as steatite) can be cngrased by the unaided iron graver; some require the (comparatively) blunt point of a metal drill (used with emery). All stones can be cut with the adamas-point, (that is by diamond or sapphire); but the tool which is the most effective of all is the rapidly revolving drill."

Theophrastus makes the following statements with regard

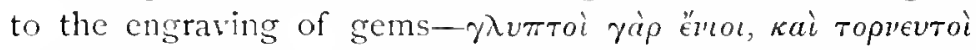

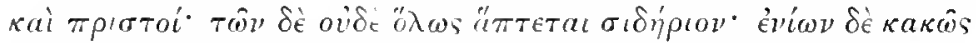

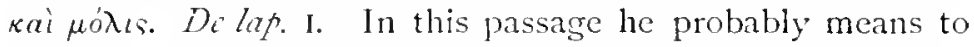
say that gems are engraved cither with the diamond-point

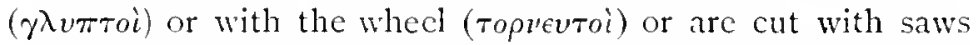
$(\pi \rho \epsilon \tau o i)$; some are not even scratched by iron. Again at

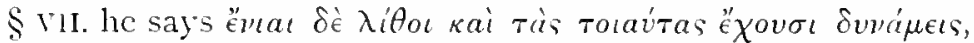

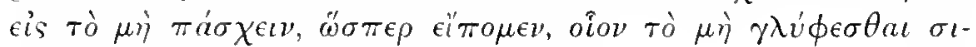

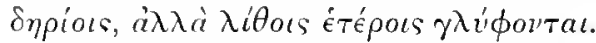

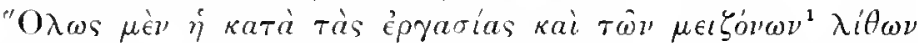

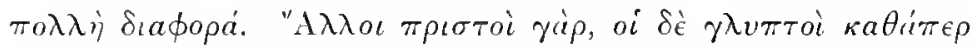

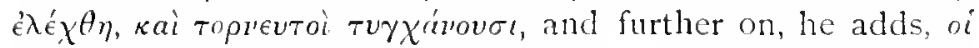

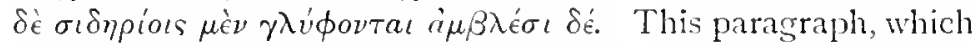
is unfortunately full of lactuar, seems to be the one from which Pliny is quoting in the above mentioned passage, H. N. xxxir. 200. It is possible that the text of Theophrastus might be amended and the lacunae partly filled up by the help of this translation, which appears to be giren by l'liny from a more perfect codex than any which now cxists. The phrase "non nisi retunso" is ciearly Pliny's rendering

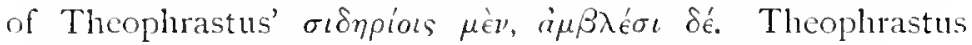
wrote his short treatise on gems about the year 315 B.C.

In most of the archaic gems, and again in those of the period of Roman decadence, the use of the drill is very conspicuous ${ }^{2}$; short curly hair of men or animals is often

1 In this passage the word $\mu \in t^{2} b \omega \omega$ is probally corrupt, since the size of gems has nothing on do with their relative harducs.

2 The archaic glandular gem in the Fitzwilliam collection hows the use of the trill clealy all over the bondy of the engle: see I'late I. No. 2. 
represented by a series of close-set drill holes even in work of a sood period.

The general blocking out of the figures secms to have becn mainly done with the bow-drill, the final modelling and details being put in afterwards with nther tools. Some ancient gems hate never been carricl further than the initial drill-work, and look unfinished.

There are many of these among the 6th and 5 th century scarabs in the British Museum; stch as No. 447, a red jasper

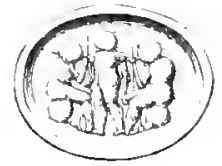

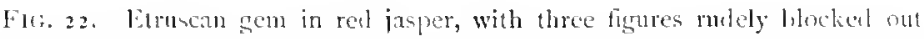
with the blunt drill (1he "retunumu" of Pliny). The inecribed names [AГА ] $\mu \in$ -

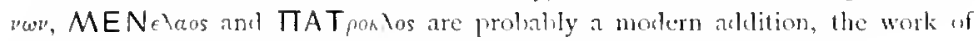
wome stealer, in orter to enhance the selling value of the $\mathrm{g} \mathrm{cm}$ : real size.

scarab, which represents a standing hero between two seated figures; see fig. 22.

The same use of the drill can frequently be seen in Grect coins, especially for the hair of men', and very commonly in the ligends, the letters of which were formed by first drilling in the iron die a small hole at the end of cach straight stroke, and then lines were cut joining the pairs of drill-holes'.

The emery drill on a larger scale was a very important masons' and sculptors' tool in ancient Egypt and among the carly Greels, as is mentioned above at page 104 .

1 This halit of ropreacenting hair of a crisp, curly sort by drill-holes secun to have influenced the freek sase painters of the lest "rest-figme" periukl. The

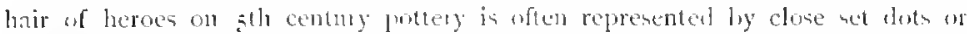
pellets of the fine creamy black ctimed, giving a fine effect of texture and gloss liy the wight relicf of the emamel alots.

"For example the legends un the later tetratrachus of Athem with Magistrates" names are very olvionsly formed in this way, the wotk being cuarse in excention. In better work the drilled teminations are less conspicunus.

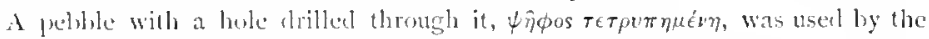

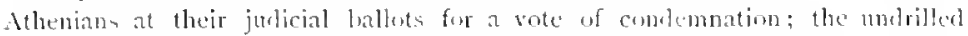

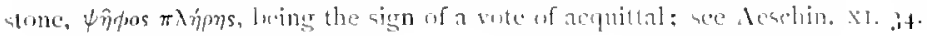


Without it, it would have been impossible to work the intensely hard basalts and granites of Egypt, or the conslomcrate of Mycenae and Tiryns.

Tulite-

drills.

Alatiosti.

Tibledrill used for sicms.

TILE TUHULAK JMJLL: for work on a larger scalc a tubular form of drill was used; that is, a bronzc tube, cither with loose emery powder, or clsc with minute crystals of corundum set along the worling edse of the tube.

This tubular drill was known in Egypt as carly as about 4000 I.C. Within recent years its usc has becn revived for blasting and quarrying hard rocks. If this tool had not been re invented the Alpine tunncls would have been practically. impossible.

The tubular drill was also used by the Greeks for such purposes as hollowing out their alabaster perfume bottles ( $i \lambda a \beta i \sigma \tau o \iota)$, and for many other similar processes.

For such minute work as gem-cngraving the tubular drill was rarcly cmploycd, but clcar marks of its usc arc to bc secn on some of the archaic Grcel lenticular gems, as, for cxample on one, cut in carnclian, in the British Muscum (scc fig. 23), which has a pillar-likc object, probably a tall firealtar, betwecn two rampant lions-very much like the relicf over the well-known "lion-gatc" of the Acropolis of Myccnac.

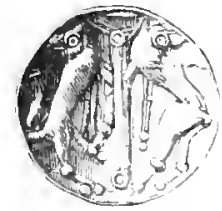

Fif. 2.). Early lenticular gen in carnelian, which shows clearly the use of the wheel and of two kinds of drills-the tulunlar and the solid drill; reat siat. Cf. gems in 'Equmepis, I $888-9$, Plate io.

In this interesting gem (No. I06, Brit. Mhus. Cat.) the cyes of the lions and the terminations of the pillar are sunk with minute tubular drills. The rest of the work is cngraved with the solid drill, and with the little wheel.

Kirllime According to Pausanias (I. 26 ad fin.) Kallimachus, the chuss. inventor of the Corinthian style, was the first to use the drill

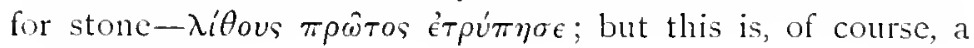


mistake. Drills were used in Egypt for hard stone nearly 4000 1.C., and in Greece many centuries before the time of Kallimachus, whose golden lamp in the temple of Athene Polias on the Acropolis must have been made after the Persian invasion in $480 \mathrm{~F}, \mathrm{Cl}^{1}$

Another instrument used for straight cutting or slitting was a wire strung on a bow. The spring of the bow kept the wire taut while it was being drawn backwards and forwards with the usual supply of emery and oil, thus cutting like a saw into the gem. On a large scale this sort of wire saw (serra) was used by the Romans in cutting the thin slabs of coloured marble (crustac) used so much under the Empire for wall decoration. For the softer marbles, sharp sand and water were used instead of emery.

2. TIE WHeEL (tópros, rotula $)^{2}$ : this was a minute disc of bronze which was set on a long, slender shaft of wood or metal and worked with a bow and tube like the drill; emery and oil being applied to it in the same way. The wheel cut, of course, at right angles to the shaft, not in the same direction as the drill did. According to the direction in which the workman moved the little wheel it could cut either a loug line or a broad sunk surface ${ }^{3}$.

In the early lenticular gems its use is specially visible, and indecd to use the wheel for any other purpose than blocking out the design requires exceptional skill on the part of the operator; otherwise it produces a very coarse and clumsy style of work; sec fig. 24, which shows an carly. lenticular gem cut in rock crystal.

Examples of obvious wheel-work among the Fitzwilliam gems are the wings of the cagle on the glandular gem, l'late 1. No. 2 ; and the scarab of Kreontidas, Plate 1. No. 4 . The wheel is largely used by modern gem-engravers in Italy, who call it il rotellino.

1 For further information ahout Kallimachus, sec Vitruvius, IV. i. Io.

2 The word tomms is also wed for a lathe.

3 This sort of whed and the drill are hoth anong the most impurtant imeturments of the modern dentist: but he uses hard steerl, insteal of coples and encry, having a less refractory sulstance to deal with. 
Whathise. Another kind of wheel was used in later times for quite a different purpose, namely for cutting slices of scems, $\lambda_{t} \theta_{0}$ mpiotys. This was a very thin disc of metal, several inches

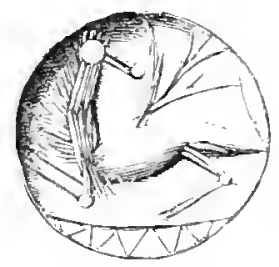

Fri: 27. Rulely worked lenticular gem, which illustrates the une of the wheel, the drill and the adamas- or dianmemi-point; real size. Thin sem and that shown in tig. 2.3 late possibly as early as $\mathbf{1}_{4}$ or 1 : centuries B.c.

in diameter, which was fixed as it revolved, the stone being pressed against its edge, like the circular saw of the modern timber-merchant. In this case, as with the other wheel, the actual cutting was donc, not by the metal of the whecl, but by the emery and oil with which it was kept constantly charged.

Exiching

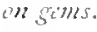

layminis lirswen, $1,527$.

Jolishing frocess.
The Prophet Ezechicl in his lamentation for the doom of the ling of Tyre (xxviii. I3) gives a long list of precious stones, followed by the words (translated in the Revised Version) "the workmanship of thy tabrets and of thy pipes"; and in one version of the Latin Bible "opera tympanorum tuorum et foraminum tuorum." In his Numismatique dis Satrapies, P. 71 , the Duc de Luynes has made the interesting suggestion that the tympana and foramina of Ezechiel are really the ordinary tools of the gem-engraver, the "wheel" and the "drill." The tympanum probably means, not the cutting whecl, but a sort of revolving drum made of wood, which, when covered with powdered haemative or ochre, was used to polish the surfaces of gems, the process called

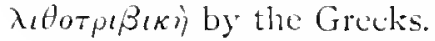

Another, yuite different sort of wheel was used, not for engraving the designs on gems, but merely for shaping roughly the stone.

This was a whel made of fine whetstone, such as the black "Lydian jasper," shaped and fitted and supplied with 
water exactly like an ordinary grindstone for sharpening cots. knives, but on a much smaller scale. It was probably werticed with a treadle, like a lathe, and the gem was pressed against it as it revolved. The flat field of a signet gem and its rounded edges were probably, as a rule, formed with this instrument, the polishing being done afterwards with dry powdered ochre.

3. TILE IMAMOND-P(BNT: this toof was not used with the bow, but was held in the hand like a pencil, or like the "dry-point" of a modern etcher.

It consisted simply of a natural crystal of ademars, set in a bronze or iron handle; see O.T. Form. xiii. I, "The sin of Judah is written with a pen of iron, with the point of a diamond." Pliny describes this tool in his paragraph on the ademas (Hist. Nat. Xxxv11.60) under which name is included both the true diamond and the white saffhire, which comes next to it in hardness.

He says-"cxpetuntur hae (crustac, chips) scalptoribus, ferroque includuntur nullam non duritiam ex facili cavantes."

The truth is that whole crystals, not cristac, have the best cutting power, and it is probably these that were mostly used by gem-engravers ${ }^{1}$.

Less hard substances than the adomas were used sometimes in the same way. Herodotus (VIl. 69) speaks of the Aethiopians pointing their arrows with the same sort of hard stone or flint that was used for engraving signets; $\lambda i t$ os o $\xi_{i}$ 's

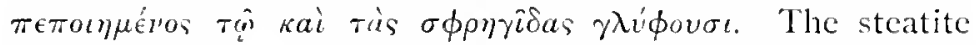
scarab-signets of Egypt are soft cnough to be cut by obsidian or flint. Many arrows tipped with these stones have been found in Upper Egypt, and cven in the tombs of Thebes.

Most of the details and all the artistic finish of a well engraved gem was given by the use of the diamond-point, which allowed an amount of freedom of touch in the artist's hand far beyond what could be got with any of the other more mechanical tools. It was howerer much more laborious

1 The molern glazier's diamonl is alway's a matural crystal; a splintered us cut bit of diamond will realily scratch glass, but would not make the elecpe slit which is necessary to divide a slieet of grlass neatly. 
Us of to use it, and required great technical skill on the part of the ditumint. foint. engraver. By working over and over the same place with the point its scratchy lines could be got rid of, but on some of the gems of finest style and period the artist has not troubled to do this completely, and has left some of the original lines in a way that adds to the spirited beauty of the $\mathrm{gem}$, though at a sacrifice of high finish. This is a point in which the mediaeval or modern forger is specially liable to fail; he is usually too careful to leave no trace of the actual tool-work.

Gemes in The use of the diamond-point can be clearly traced in Brit. ilus. one of the most graceful grems in the British Museum (No. 562), which has a figure of a girl dressed in a long chiton, standing and holding a lyedria.

The lines of the hair, the long straight folds of the drapery, and even the findria in her hand are all executed with the point: thus giving a sort of sketchy look to this very beautiful design, which probably dates from the time of Pheidias'.

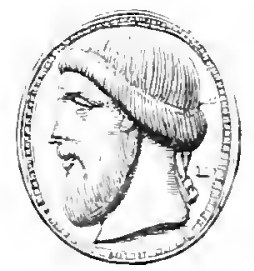

Fic. 25. Gireek gen with a heal of Zens, of very noble style, inscribed EE: the nse of the dianond-point in working the hair and beard is very distinct.

Another very beantiful gem in the British Museum (No. $464)$ illustrates the use of the diamond-point; see fig. 25 . This is a scarab of green jasper from the Blacas collection, with a head of Zeus of most noble style, within a cable border, dating from the first half of the $5^{\text {th }}$ century i.c. The delicate lines cut with the diamond-point are specially visible in the working of the hair and beard of this head.

1 Among the Fitzwilliam grems. the ane of the puint is most visible on Nos. 6 . 12 and $1 \%$, I'late $\mathbf{I}$. 
See also above, fig. 16 at page 25 , in which the hairs of the Satyr's tail are scratched in with the same instrument.

Something very similar to the style and touch of $5 \mathrm{~cm}$ engravings is to be scen in some of the finest Greck vase paintings of the late black-figured style, dating from the middle or latter part of the 6th century B.C.

The inner markings with incised lines on these blatk figures are in many cases executed with a gem-like delicacy and minuteness; and it is very probable that the fine lines, sharply and clearly cut through the hard black enamel, were actually executed with the jewel-pointed tool of the glyptic artist. This is specially noticcable in the delicate wavy lines of the hair both of men and animals, and indeed in all the incised lines of such miniature work as that on Mr Malcolm Macmillan's little vase from Thebes, mentioned above at page 24 .

Practical experiments on fragments of Greck pottery have convinced the present writer of the great difficulty of producing a perfectly clean line on the hard enamel with any point of metal-even one of hard steel, such as the Greeks did not possess. The diamond-point on the other hand, which was a familiar tool to the ancient Greek, produces the cleanest lines with ease.

4. TIIE File (lima). A very useful tool for smoothing level surfaces on gems, such as the flat field of a signet, was made by a mixture of emery and melted resin ${ }^{1}$; when hard this mixture has a very keen cutting power. This is probably the tool that Maccenas alludes to in his letter to Horace-

"Nec quos Thy"lica lima perpolivit

Ancllos, neque jaspios lapillos." Anth. Lat. 1. p. 413.

As is mentioned above (see page 70) the lima was the tool held by the statue of the bronze sculptor and gem-engraver Theodoros as a symbol of his craft.

One form of lima, used for working in metal and also for cutting the softer stones, such as steatite, was probably a file made of iron, not unlike those which are now used. It rould

I The modern method is to mix melted shell-lac and diamond dust.

M.

Inciseil lines on ineses.

Ditmontfint.

Thifile. 
however be of no use for working the harder stones, such as those of the quartz class, and still less those of more refractory. kind; see page 157 , where a table of the relative hardness of gem-stones is given.

Apuleius, in a curious passage near the beginning of the second book of his Florida, mentions the use of the lima and

Ring of llifpias.

Withod of polishing.

rastegems. the tormes by the Sophist Hippias, who wore a gold ring set with an engraved gem, entirely the work of his own hands, both stone and setting.

5. Tile FiNal rolisil. After the sunk design of an engraved gem was completed, it was necessary, both for the sake of its beauty, and also to prevent the wax or clay of the seal from adhering to it (see Pliny, $H . N$. xxxvil. 104), to polish, as completely as possible, the internal sunk part.

This was done in a laborious way by working the finest powder of some metallic oxide such as haematite, or ochreous earth, into all the depressions of the work with a soft point of wood, a bird's quill, or some other yrelding and slightly elastic substance. The flat field of a gem was polished with much greater ease by rubbing it on the surface of woollen stuff sprinkled at first with emery and then funally with the finer powdered ochre. The revolving drum (tympamm) already mentioned was used for this purpose.

Tile technique of "PAste" Gers. Paste, which is only another word for the finest sort of glass, was made with great skill by most classical nations-especially by the Phoenicians, the Greeks and the Romans. In splendour of colour, in luminous texture, in hardness and durability, the ancient pastes are very superior to those made in modern times. One reason is that modern pastes or false jewels are largely composed of oxide of lead, the objcct being to increase the "fire" or lustre of the paste, though at the expense of its hardness and durability.

In ancient times, before the modern custom of faceting jewels had been invented, fine deep colour was the first requisite, and sparkle or lustre was but little regarded ${ }^{1}$.

1 The materials used in making ancient pastes are mentioned below, sce page 15.3 . 
In making a paste signet the process was this-a mould was makle from an cngraved gem by pressing it against a Moulding of pastes. mixture of clay which had been ground in a mortar, together with a large proportion of fincly powdered pottery, till it was a perfectly smooth, plastic and homogeneous mass. The clay mould, with the impression of the original intaglio in relief, was very carefully baked in a potter's kiln, and then a red-hot lump of the glass or paste, in a soft pasty state, was gently pressed upon the mould till it received the complete imprint of the original gem. If clone carefully, by a skilful glass-worker, the result was an almost exact facsimile of the original intaglio.

When it had cooled, its ragsed edges and the rough back were cut smooth and polished by the lapidary's wheel and cmery powder, till it was ready for setting in a ring.

In the British Museum there is a large colourless paste (No. I 5 I8) with a portrait head of Aristippus, which has never had its edges cut smooth: it is still surrounded by a ragged border, just as it came from the mould ${ }^{\text {. }}$.

Among the finc collection of terra-cotta objects from Tarentum, which were presented by $\mathrm{Mr}$ A. J. Evans to the Ashmolean Muscum in Oxford, are included a number of clay moulds for making paste gems. These are simply lumps of clay on which, while soft, an engraved gem has been impressed, giving the device in relief: this relief of course would be again reversed when the soft glass was pressed into the clay mould, thus forming a paste intaglio.

Among these moulds are two standing figures of Dionysus, two of a winged Victory writing on a shicld, and more than one of Eros.

In some cases antique pastes have been made, not by any moulding process, but by using the ordinary tools of the gemengraver; treating, that is, the paste exactly as if it had becn a real jewcl. One of the finest examples of this kind of paste

1 An account of the making of paste gems is given by IIeraclius in lis treatise $D_{e}$ drtilus Romenorzm, written in the gith century.

A MS. of this work, in the library of Trinity Cullege, Cambrilge, was pullished by kaspe, London, 1783 . 
Paste of is No.62I in the Marlborough collection (Story-Maskelyne's Guato. Cataloguc, i 870 ) engraved with a standing figure of an athlete of the Diadumenos type, with the name CNAIOY, probably that of the owner of the $\mathrm{gem}$, partly obliterated by repolishing. The quality of this paste, which once belonged to Pope Clement VIII., is so fine that it has usually been described as a jacinth or beryl of exceptional beauty, even by experts such as the gem-engraver Natter.

Occasionally a combination of both processes was used, the paste being first cast and then its device worked over and sharpened by the use of tools-a somewhat analogous process to that employed by Greek and Roman moneyers, who frequently first cast and then struck coins in high relief.

Paste Sia mabaiouls.

Fint biakins.
Many scarabacoids of colourless paste, too large for rings, have been found within recent years in Cyprus and elsewhere in Greece. Nos. $S$ and 9 in the Fitzwilliam collection are examples of these: the combination of moulding in the device, with cutting on the edges and back, is very obvious in these two pastes.

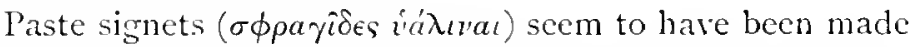
in great numbers for the poorer classes, both among the Greeks and the Romans of the Empire. As a rule they were not mounted in gold rings, but in silver, bronze or iron-in many cases the inferior metals were plated with gold ${ }^{2}$. The signets which cost only 3 obols (Aristoph. Thesm. 424; see p. 37) were probably paste copies, set in bronze.

Paste gems very frequently were set with a backing of polished metal foil, which, by reflecting the light through the paste, gave it increased brilliance and depth of colour.

The same method of setting was often adopted for real stones: Pliny (Hist. Nat. xxxvir. 106) speaking of one sort of sard, says "argenteis bratteis sublinuntur"; while sards of a different colour "brattea aurca sublinuntur." At Hist. Nat. xxxui, 126, Pliny describes two methods of setting gems, either with an open bezel, or with a backing of gold-coloured

1 In England and France, during the 1 th $^{\text {th }}$ and $15^{\text {th }}$ centuries, it was usual for the jewellers' guild in each town 10 have a rule prohibiting its members from setting faste gems in real golel, or rial gems in plated metal. 
foil-" hae funda includuntur perspicuac, ceteris subicitur aurichalcum."

A colourless paste or crystal was sometimes made to imitate a carbuncle by backing it with a crimson foil. Many other tricks were known to the ancient jewellers, and Pliny. gives various directions how to tell true from false $3 \mathrm{cms}$ by testing their weight, hardness and apparent fecling of coldness, all of which qualities are greater in a real stone than in a paste: sec Hist. Nat. xxxiri. 98 and 128 and 198. At S 197 Pliny wans his readers against sham sardonj'xes, made by cementing together three slices of different coloured stones so as to produce the three layers of the natural gem.

In most cases, however, paste gems must have been sold as honest copics: as works of art they frequently have great merit, both from the sharpness of their impression and from the splendour of their colour.

In the tombs of various parts of Cyprus a considerable number of large rings have been found made wholly of glass. The hoop of the ring is usually of colourless slass, and the bezel is filled with a large paste brilliantly coloured green or crimson to imitate an emerald or a carbuncle; they are not cngraved with any device, but have a plain convex surface. These false jewels were fixed in the hollow prepared for them with a little fine cement, which in many cases has perished and allowed the coloured paste to fall out.

These rings are very decorative in effect, owing to the magnificent deep colour of their imitation jewels. The collection of glass from Cyprus in the Fitzwilliam Museum contains many fine examples of these rings, especially one with a large paste emerald still in its place.

In Roman times paste cameos were very frequently made; the commoner sort being merely casts, like the signet or interglio paste, but the finest are all worked orer and finished with the gem engraver's tools.

The Portland Vase is the most magnificent example of what may be called a paste cameo on a large scale. In it and similar glass vases there was no moulding: the whole work was done cxactly as if the artist had becn cutting an 
Pomlund ony.x. That is to say, it was first completed as a deep blue i'ase. $\quad$ vase, completely covered and the blue surface hidden by an opaque layer of white glass; and then, when it was quite cold, the engraver set to work and cut and drilled away the white upper layer-modelling his figures in the white layer and cutting down to and exposing the blue body of the vase to form the ground of his reliefs ${ }^{1}$. An excellent description of the Portland Vase is given by Mr A. H. Smith in his Cataloguc of the Gems in the Pritish Musim, p. $225 \mathrm{seq}$.

Signed Among the many examples of Greel art of the 4 th stlass.

Fieats of skill.

Late io. man slass. century B.C. which have been found in the tombs of Kertch are some elaborate glass cups, which are specially notable for their having the artist's name on them, followed by the word EחOIEl.

Cameo worli on glass ressels, like that on the Portland Vase, was not uncommon in Egypt during the later Ptolemaic period and in Rome under the carly Empire; it was usually very beautiful both in design and execution.

It is essentially gem-engraver's work, and in some cases shows almost miraculous skill in the way the workman has undercut his design in the brittle glass.

The most wonderful feats of skill in this direction belong to the time of extrene artistic decalence, when the Romans took pleasure in seeing the most lavish waste of an artist's labour, owing to his working in some material which was utterly unsuited to his design. Hence the Roman love for statues in porphyry, or even obsidian and rock crystal with other costly absurdities of that kind.

Amazing examples of this skilful use of the gem-engraver's tools are to be seen in some cups of greenish glass, which have, on the outside, in a ruby red layer, an open net-worli of linked rings, all cut out of the solid glass, and under-cut, so that, with the exception of a few slender pins of glass, the inner cup is quite free from its net-work covering. Several cups of this pattern have been found at various places; all of cuurse more or less broken. Usually they have the owner's

I Mlartial (xiv. y4) mentions this lind of work, which he calls toremata ritm, that is glass worked with the gem-engraver's tools. 
name in large letters along the top-each letter in red gliss being under-cut and joined to the pale sreen cup bencath only- by two or three of the slender pin-like supports.

The best preserved of these wonderful cups is in the Strasburg Muscum; it bears the name of the Emperor "Maximianus Ierculcus Ausustus," who was put to death by Constantine's order's at Massilia in 310 A.D. This grives the date of these goblets covered with the wheel and drill-cut net-work.

Pliny gives (Hist. Nat. xixir. 190 to 199) a very interesting account of the glass-maker's art.

At $\$ 193$ he mentions the three principal methods of working ormamental glass. After the materials were fused together into a "frit," (he says) "ex massis rursus funditur in officinis tinguiturque, et aliud flatu figuratur, aliud torno teritur, aliud argenti modo caclatur," that is, "after remelting in the furnace, and adding the colouring matter, some of the glass is formed by blowing, some of it is cut on a allat, and some of it is arked in riticf like silver plate." Examples of ancient glass shaped with emery on the gem-cutter's wheel or lathe are not uncommon, and the term calduture woukd naturally be applicd to work in relief such as the Portland Vase'.

Among the gems in the Fitzwilliam collection, No. 37 is a good cxample of a gem, cast from a well-executed head of IIermes, in paste skilfully coloured to resemble a fine golden sard.

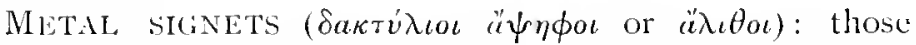
rings which have the device sunk in a metal bezel were Pliny on glass.

formed in various ways. The fincst have the design int with tools in the same way as if they had bcen of stonc. Examples of these, signed by the artist, are described above at pagre 73 . Others, especially the gold Etruscan rings, have the device

\footnotetext{
1 Une curious class of Roman pottery, ustally in the form of bowls of coarse "Samian ware," is ormamenterl by simple pattems deeply cut with the lapidary's stone wheel on the hart clay, after it had been fircel in the kiln. 'The lirtish Musem (Rumano-liritish clepartment) possesecs many cxannles of these wheel-cut buwls from various british sites; but they are probably of Gaulish worknanship.
} 
stumped from a die on a thin plate of gotd, which was then sotdered by the goldsmith into its place on the ring.

Castrinss. A third method, used for the cheaper class of bronze rings, was to cast the bezel in a relief moutd; but this plan left the impression blunt and spiritless, unless afterwards touclied up by tooling ${ }^{1}$.

1 On the technique of gem-engraving as practised in the first half of the eight-

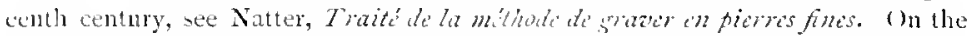
whole Natter was perhaps the mot silful of all copyists of antique gems. In some cases he certainly forged the name, of ancient antists, but not unfrequently, he signed his uwn work $Y \triangle P O Y$, 'Natter' meaning a 'water-snake' in German. 
CHAPTER X.

Gems in Medialeval Times.

OWING to the extreme decadence of the glyptic art during the early middle ages many of the French kinss and Emperors of the West, from Charlemagne downwards, frequently used antique gems for their royal signets. Charlemagne himself sealed his edicts with a portrait head of Marcus Aurelius. Louis 1., on a document of 816 A.D., has imprinted as his seal a head of Antonimus Pius.

The same practice was adopted by various English kings before the Norman Conquest, such as Offa King of Mercia and several others.

The legent on these seals is added on the gold border which frames the ancient gem.

In most cases the gem itself is now lost, but we have impressions of them on countless carly charters. Some of these impressions are from gems of very fine workmanship, dating from as early as the times of the Diadochi, but more frequently they are inferior works of late Roman date. One of the finest of these gems, known from its impression on a charter in the British Muscum, was used as the royal signet of Odo or Eudes, who was King of France from 888 to 898 A.D. It is a noble contemporary portrait head of Seleucus IV., King of Syria, who reigned between 187 and I 76 I3.C.; see Arch. Journ. Xil. p. 261.

There were however a certain number of large signets and other intaglios engraved on rock crystals by artists of the Byzantino-Rhenish school for the early Emperors of the West. Impressions exist of a signet of Lothair 1. (840- 
S55 A.D.), with a full-faced bust of the Emperor, very rudely cut. Another of the same Emperor's signets still exists, set in the gold foot of an altar-cross in the Cathedral of Aixla-Chapelle. It has a profile portrait of Lothaire in a helmet, and round the rim of the crystal itself is engraved the inscription XPE A ADIVVA - HLOTHARIVA - REG., "O Christ help King Lothaire'." At the same time large intaglios were cut in rock erystal for various decorative purposes; to ormament gold shrines or reliquaries, and for personal jewellery. The British Museum possesses one of the finest examples of this-a large circular intaglio cut in very brilliant erystal, which was worn as a morse or copebrooch by the Abbot of Vézor.

It is minutely engraved with Biblical subjects and is inscribed LOTHARIVS - REX . ME FIERI FECIT.

During the mediacval period the use of seals or signets was no less important than in classical times. Part of the ceremony during the consecration of a Pope, a cardinal or a bishop consisted in investing him with an official ring. That used at the installation of a Pope has been for many. centuries known as "the fisherman's ring," from its device, a figure of St Peter fishing from a boat, cut on the gold bezel. Hence the heading often placed at the beginning of Papal Briefs and other documents "Sub Annulo Piscatoris." In many cases, especially cluring the Ioth to the I 3 th centuries, when the art of gem engraving was almost extinct, episcopal signets were in the form of a gold ring set with an ancient Greek or more commonly a Roman gem.

These were frequently selected with a device to which a fanciful Christian meaning might be given, such as the head of Jupiter which was used by the Benedictine monks of Durluam as a portrait of St Oswald; it was set in a gold mount on which was inscribed 4 CAPVT.SANCTI . OSWALUI - REGIS - ; another example is the three-headed sryllus monster used as his signet by Archbishop Roger,

1 It in illustrated in Vol. I. of Cahier et Martin, Vhlanges at Archolegat: see also thit. Foum. xill- p. 222 . 
with the ligind added CAPVT . NOSTRV. TRINITAS. EST ; see Vitusta Monumenta, Vol. I., Pl. 59 '.

For many centuries after the fall of the Western Empire the belief in magical signet-gems survived, and, to some extent, it lasted throughout the Middle Ages. Even the most orthodox Prelates of the Church did not wholly disbelieve in the magic of gems. Many Bishops used for their episcopal ring of office an Abraxus gem; as for example Seffrid, Bishop of Chichester from 1 25 to 1 151, whose gold ring, set with an Abrazas jasper, was found in his coffin, and passed into the Waterton collection; see Arch. Jour. xx. p. 224-23S. In the present year I 890 , when the tomb of Hubert Walter, Archbishop of Canterbury from 1193 to 1205, was opened, his gold ring was found set with a plasma on which was cut the Cnoubis lion-serpent ${ }^{2}$, like No. 106 in the Fitzwilliam collection.

In the I 5 th century, together with the revival of classical learning, there was a fresh outburst of superstitious belicf in the magic efficacy of engraved gems, even among the most enlightened scholars of the age, such as Lorenzo the Magnifi. cent, Pico della Mirandula, Pope Leo X., and many others.

Throughout the Middle Ages, as is mentioned above, great numbers of antique gems, and especially cameos, were used to decorate the most costly of the gold reliquaries. The celebrated beryl intaglio of Julia by Euodos, mentioned at page 74, was for many centuries one of the many gems which decorated a gold shrine in the Treasury of the Abbey of St Denis, near Paris. This magnificent $\mathrm{gem}$ was set face downwards on a backing of brilliant gold foil, and thus presented the appearance of a translucent relief. This method of setting engraved gems was frequently practised by the

${ }^{1}$ For further infurmation on this class of signet, see Arth. Fum. Vol. xx.

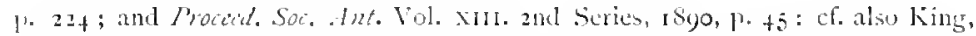
Antiqu Gims and Rims, 18;2, p. 386.

$\because$ The crozicr of the same prelate liad its knop set rounct witl four anticue gems, of late Roman work, coarsely cut. The three which still remain in the crofier are

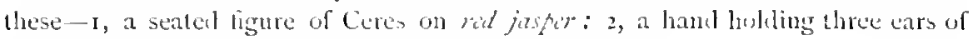
wheat, on carnelian; and 3 , a stag, also on carmertian. 
mediaeval jewellers, and if the stone is a very transparent one the effect is very soft and beautiful.

Several of the numerous antique gems which studded the famous chasse of the Three Kings of Cologne were set in this manner on foil, face downwards.

In spite of the great decadence of technical skill the art of gem-engraving never wholly dicd out, though for many Whal centuries it was but rarely practised, partly owing to the use stith. of signets made wholly of silver or bronze'. If an engraved gem was used, it was usually an ancient Roman one, set in a metal collar on which the necessary inscription was cut. Mediazinl There are however a few gems engraved in the I th century stims. in existence, of very fair workmanship; as, for example the signet of Charles V. of France, a minutely cut full face on a spinel-ruby, set in a gold ring, on which is inseribed Tel il nest, "there is none such as he." This very signet is described in the royal imentory made in 1379 . It is now in the Marlborough collection, No. $58_{3}$ : it is illustrated by King, Handbook of Gims, p. I 2S, No. 2, but is wrongly named in the text. In the same work (at page 122) King quotes Scipio Ammirato (Hist. Flor. p. 7+1) as mentioning the forging of the signct of Carlo di Durazzo in I $37 S$ by a clever engraver of gems-_" Peruzzi, il quale era singolare intagliatore di pictre." Rezizal of The great revival of gem-engraving did not, however, begin sim insraving. till the time of Lorenzo de' Medici in the latter part of the I 5 th century.

So also with regard to collections of ancient gems, al though our mediaeval forefathers showed considerable powers of appreciating their beauty, yet it was not till the 15 th century that gems were studied or collected with any real enthusiasm.

Donatillo. Vasari tells us that the great Florentine sculptor Donatello, who died in 1466 , was an ardent admirer of ancient gems and coins, and that he took antique cameos and coins for his models when he carred that noble series of medallion reliefs which still exists in the Palazzo de' Medici (or Riccardi) in Florence. 
The earliest example we have recorded of a real collection $I$ 'ul $/ I$. of ancient gens, since classical times, is that of the Venetian Paul II. (Barbo), who was Pope from I 464 to I $47 \mathrm{I}$.

He is said to have paid large sums for Greek and Roman gems of all kinds-cameos and intaglios-both for his cabinet of gems, and also to set in the numerous rings with which he used to load his fingers.

Picro de' Medici, who died in I 469 , formed a small collection of gems, which were inherited by his son Lorenzo the Pitro di Magnificent, who also acquired the collection of Pope Paul II., thus obtaining the nucleus of what afterwards became the large and important dactyliotheca Medicana. which unfortunately was dispersed in the century after Lorenzo's death.

When Lorenzo de' Medici himself began to collect gems, soon after $\mathrm{I} 469$ when he became ruler of Florence, he showed Lorensode a special love for cameos and intaglios of large size, and was eager to buy, not only antique specimens, but also the works of the very able Italian artists of his own time.

One of the most beautiful gems that any age has ever produced is the copy, on a large sard, in intaglio of the Dionede with the Palladium (mentioned at page 75), which was executed for Lorenzo de' Medici; the mark LAVR. MED. is cut on the cippus upon which Diomede is seated.

This magnificent gem, which is a more perfect work of art than any of the antique examples of this subject, is obviously the work of a I 5th century artist, having a wide margin round the figure and other signs of post-classical date.

Whether they were cameos or intaglios, ancient or contemporary, Lorenzo the Magnificent had all his most important gems engraved with his own name in large letters Diomete of Lorinso. thus, I,AYR. MED.

Many gems, especially cameos, with Lorenzo's name exist in various collections: most of these, if not antique, are exccuted in a classical manner, but one or two fine gems are in the style of contemporary Florentine art, and look as if they were the work of pupils of Donatello, while others resemble the style of Antonio Pollaiuolo. 
Delle Carnistoli.

I.ernans 'ms are?s.

Leo. $\mathrm{Y}$.

Itasari.

Finta.

One of the ablest engravers who worked for Lorenzo de' Medici was Giovanni, surnamed "delle Carniuole" for his skill in cutting camelian gems.

The fine intaglio portrait of Fra Girolamo Savonarola, now in the Uffizi collection, is one of his most celebrated works, very noble in style, and full of life-like vigour and realistic truth.

Others of Lorenzo's gems were engraved by Francesco Francia the famous Bolognese painter and goldsmith, by Marco Morctti, by Domenico (called) de' Cammei, and by Leonardo da Milano; the last two wcre both natives of Milan, and were greatly famed for their portrait heads.

Camillo Leonardo, in his Spuutum lapidum, a work on gems published at Venice in 1502 , mentions four artists as being the chicf gem-engravers of his time; these were Anichini of Ferrara, Giovanni Maria of Mantua, Tagliacarne of Genoa and Lconardo of Milan, who worked for Lorenzo.

Lorenzo de' Medici's love for gems was inherited by his son Pope Leo X. and also by various other Popes of the i 6 th century, most of whom were liberal patrons to all skilful intagliatori-a very numcrous class in Italy at that time.

An interesting chapter in Vasari's litc dei fittori \& $c$. (Part II. Vol. I. page 285 scq. in the edition of 1568 ) is deroted to the gem-engravers of the Renaissance. Vasari specially praises the works of Piero Maria da Pescia, who engraved both coin-dies and gems for Leo X.', Valerio dei Belli (il Vicentino) famed for large crystal intaglios, who lived from I 468 to I 546 . Giovanni da Castcl Bolognese, I 496-i 553 , Matteo dal Massaro, who died c. I548, Alessandro Cesati (il Greco) a native of Cyprus², Gior. Antonio de' Rossi and various other engravers who lived and worked in Milan. In another chapter Vasari mentions Ambrogio Foppa (il Cara-

\footnotetext{
1 See Arthin'. Stor. Ital. 3rd Series. Vol. M1. Part 1. p. 221; and Fitz. Whs. Cat. page xxiii, No. I.

a See mage $S_{2}$, for an account of the way in which Alessandro Cesati signed his gens.

For a general account of the gem-engravers of the Renaissance sce Marictte. Picrocs Graviés, Vol. I. P. IIt seq.
} 
Cossol, a famous Milanese sculptor and goldsmith. as beingr also remarkable for his skill in gem engraving. Most of these artists wcre also cutters of dies for coins and medals, and workers in gold and silver.

The portrait of Pope Paul IIl. (Farnces), on a medal by: Alessandro Cesati, is a very beautiful work; it was enthusiastically admired by . Wichelangelo. The rawse of this medal, with a nude figure of Ganymede pouring water on a lily plant. is a work of extraordinary skill, and strongly classical feeling in the modelling of the nude. In this respect it curiously rescmbles the figure of Eros on the celebrated gern signed by Phry-gillus, especially in the soft, melting contours of the flesh and its delicate grace of posc.

Many others of the medals, both cast and struck by Italian artists of this time and during the previous century, are works of the very highest artistic excellence. quite equalling in merit the best productions of the ancient Greek engravers of coin portraits. The earliest and on the whole the greatest of this class of Medallists was the Veronese painter Vittore Pisanello, who died about $145 \mathrm{I}$. but he docs not seem to have practised the art of gem-engraving. His medals, like ncarly all those of the 15 th century; were not struck from dies. but were cast from a wax model by the cive forduc process. and he had therefore no need to learn the difficult art of sinking his design in a hard material such as a steel die or a gem.

In the 15 th century. medals were mostly struck and so came naturally within the scope of the gem-engraver's craft. whereas under the older system the large cast medals could be produced by any sculptor in bronze, or even by a painter such as Pisanello, if he could model his design in wax.

The celebrated Benvenuto Cellini (I500 to I 571 ) was a skilful engraver of gems and coin-dies as well as a sculptor and a goldsmith. Like most of the Italian gem-engravers of the I 6 th century he deroted himself to the cutting of canicos rather than intaglios.

After Cellini's time the art of gem-engraving in Italy shared in the general decadence of all the arts from painting and sculpture downwards.

Aless.

Cisatis.

Wcituls of litu.

Tisano of

livens.

$\operatorname{tax}$ catins:

Colline 
There still were many engravers who possessed great technical skill, but their designs rapidly deteriorated in point of style or became mere servile imitations of the gems of classical timcs.

Forged Thus there gradually grew up a class of clever cngravers gichs. who, if not intentional forgers of antique gems, yet produced works which were so carefully and skilfully imitated from ancient cxamples that they were frequently sold for very high prices as being genuinc antiques.

Deception of this kind was then easier than it would be now, owing to the low standard of archaeological knowledge and criticism which was then prevalent-a state of things which lasted till the early part of the present century. Thus old collor- it happens that most famous old collections of gems, such as tions. those of the Dukes of Deronshire and Marlborough, which were formed by various wealthy collectors at a great cost during the $17^{\text {th }}$ and $\mathrm{I} S \mathrm{Sth}$ centurics, usually contain a large proportion of professedly antique gems which really datc from modern times. At present the more adranced state of the science of engraved gems cnables collectors to buy with greater judgment and with less risk of being deceived by unscrupulous dealers. 


\section{CHAPTER XI.}

\section{MATERIALS USED FOR ANTIOUE GEMS.}

OUk chicf literary sources of knowledge about the precious stones known to the ancients are a treatise by Theophrastus, $\pi \epsilon \rho i \lambda i \theta \omega v$, written about $3[5$ 13.C., and the 37 th Book of Pliny's Naturel History, which is mainly a compilation from Theophrastus and various othcr authors.

As a rule antique gems are rarely engraved on really fine and costly stones.

Mr Story-Maskelyne has remarked, in his Citalogue of the Marlborough collection, that if we have to deciele which of two gems is the original, and which the cops, it will usually be found that the modern one is on the finer stone of the two.

On the whole the seret is the most beautiful material which is commonly used for ancient engraved gems, though it is hardly of sufficient value to rank as one of the so-called "precious stones."

A well cngraved design on a clear orange or golden-tinted sard combines beauty of nature and beauty of art in a quite unrivalled manner.

The following are the chief stones used in ancient times for engraved gems and other decorative purposes.

First of all in value comes the Alisisti, Greek adipas, Adamas. "unconquered"; it is described by Theophrastus, Lap. I9, and by Pliny, Hist. Nat. xx.rvir. 55 to 60.

Neither the Greeks nor the Romans had any really scientific knowledge of precious stones, and we usually find that more than one lind of gem is classed under the same name.

M. 
[CHAT. XI.

Siltmas.

Tists for Adamas.

Trat diamond.

Dronse statuitic.

Themont iris.

The word adamas is cortainly used both for the diamond and for the white sapplive.

In one place (H. $V$. xxxvir. 56) P'liny seems to describe the double pyramidical shape of the natural crystal of the true diamond when he say's the adtamas is formed "ut si duo turbines latissimis suis partibus jungantur."

but when he goes on to say $(\$ 57)$ that the adamas will not break if struck by a hammer on the anvil, and that it will stand the test of fire, he is certainly speaking of another and very different stone.

The diamond is easily broken along planes of cleavage parallel to the natural faces of its crystal, and, being composed of pure carbon, it is the only gem that is combustible.

The mistaken application of these two tests has caused the destruction of a great many newly found diamonds even in the present century'.

It is fairly certain that in ancient times it was considered impossible to cut or polish the true diamond on account of its excessive hardness. In those rare cases in which a true diamond occurs in an ancient work of art it is in its natural crystalline form, unworked by the lapidary.

Examples of its use are very rare.

The most remarkable case, probably unique in Hellenic art, is a very beautiful bronze statuette in the British Museum, about seven inches high, of the finest archaistic work, probably of the latter part of the 5 th century i.c. The motive of this figure is similar to the numerous marble archaic female statues, which have been found on the Acropolis of Athens, among the broken fragments resulting from the Persian sack in 4SO B.C.; see MIrs Mitchell, Ancient Sculpture, p. 280.

With one hand the lady holds up her long chiton; in the other hand, outstretched, was a bud or flower. Minute natural crystals of diamond are fixed in the pupils of the eyes, giving a wonderful look of life and spirit to this masterpiece of Greck plastic art.

1 kecent examples of newly found cliamond lreing festroyed in this way in the

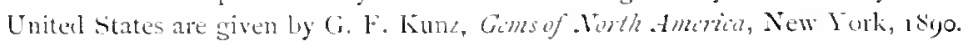


The crystals are so minute that without a close inspection they might easily pass unnoticed ${ }^{1}$.

Perhaps the only other known cxamples of antique diamonds are those in a few rare Roman rings of a late

Diumont Imperial period.

The Watcrton collection of rings contained one of these, with a diamond octahedral crystal set in a gold ring, surrounded with a border of picrecel open work, dating probably from the $4^{\text {th }}$ or 5 th century A.I.

It was not till the latter part of the $5^{5}$ th century $A . D$. that the discovery was made that a diamond could be cut and polished with its own powder. Till that time, throughout tho Middle Ages, the natural crystal was used uncut, as it was in classical times.

The well known badge of the Florentine Mcdici family is an example of this: it consists of threc ostrich feathers passed through a ring in which is set a natural pyramidical crystal of diamond.

The alamas of the Vulgate is translated "diamond" in the Authorised Version of the Old Testament (Exodus, xxix. IO-I3), where the list of the twelve gems on Aaron's breastplate is given.

But this stone cannot have bcen the true diamond, as on it was engraved the name of a Tribe, "like the engraving of a signet," a feat which was quite beyond the power of any ancient engraver, even the skilful Phoenician who probably cut and engraved the gems on the Jewish High Priest's "rational."

Ezechiel, xxviii. I3, gives the following list of gems (English Version) "sard, topaz, diamond, beryl, onyx, jasper, sapphire, encrald, carbuncle." Here again the word "diamond" is probably wrongly used for some other hard, colourless stone: cf. Apocalyhse of St Foln, xxi. 19 to $2 \mathbf{I}$.

In most cases, it scems probable, by the word adamas is meant the white sapplire, a stone which comes next to the diamond in point of hardness.

1 This wonderful statuette is sail to have been found at Verona, but it aplears to be of the finesl Attic Workmanship.

Aaron's

briats

platc.

list. 
The jewel-set tool mentioned by Pliny' (H. N. xxxvil. 60) may have been set either with splinters of the true diamond or of the sapphire.

Sutphir. The modern sAIPIIIRE is probably the Hyacintilus, véécutyos, of classical authors; Pliny, H. N. xxxirit. 126. Solinus truly says that only the diamond will scratch it. The sappirus is quite a different stone, as is mentioned below.

The true sapthire is a pure crystalline form of cornudum, an oxide of aluminium, $\mathrm{Al}_{2} \mathrm{O}_{3}$ of a fine blue colour.

It is very rarcly used for ancient gems, partly, no doubt, on account of its extreme hardness, which makes it very difficult to engrave. The few really antique examples of work on the sapphire are mostly of the Imperial Roman period; it appears to have been very rarely used by the Grecks, except as an ornament for jewellery.

The Narlborough collection contains one of the most beautiful engraved sapphires in existence, a Medusa head in full face, of the first or second century A.I., finely cut on a pale blue stone; No. 98, Mart. Cat.

No. 485 in the same collection is a good contemporary portrait of Caracalla on a large sapphire of good quality.

Sar. The star-sapplize, when held in a strong light, show's inside satphive. it the figure of a six-rayed star, the result of its peculiar crystalline structure.

This is probably the astrion of Pliny (Hist. Nat. xxxint. 132), an Indian gem which he describes thus--" huic intus a centro stella lucet fulgore pleno lunae."

A variety of this was the asterior (\$ I I I) found in Carmania and in India: the latter kind, Pliny says, is difficult to cut or engrave.

It is doubtful whether any ancient examples exist of the use of this stone for engraved gems.

Rithy. The KUBY is chemically the same as the sapphire, only with different colouring matter.

The finest examples have the tint of pigeons' blood. The ruby appears to be one of scveral precious stones which were included under the name $\ddot{t}, \theta \rho a \xi$ and carbunculus, a red-hot coal ; P'liny, H. N. xxixin. 92 to 98. 
Theophrastus speaks of quite a small $\ddot{a}, \theta \rho a \xi$ being worth as much as 40 gold staters, so he is probably speaking of the

lithei of ruly. ruby, not of the carbuncle.

At the present day a fine large ruby is worth much more than a diamond of the same size: whereas rubies and diamonds of less than one carat in weight are of about the same value.

In the i6th century, according to Benvenuto Cellini, a ruby of one carat was worth eight times as much as a diamond of the same weight ${ }^{1}$.

Antique sems engraved on the ruby are very rare, even more so than engraved sapphires, but it was occasionally used Antiqui rubics. in Roman Imperial times for small cameo heads. In the Devonshire collection there is a rery late Roman figure of Venus Victrix cut in intaglio on a ruby of very great beauty, but, with very few exceptions, engraved gems on the true ruby are either of mediacval or modern date.

Nearly all that Pliny writes under the heading carbunculus seems to refer to the garnet or carbunde.

Possibly Pliny means to describe the ruby (H. N. xxxyll. 99) where he mentions anthracitis... fossilis carbonibus similis,

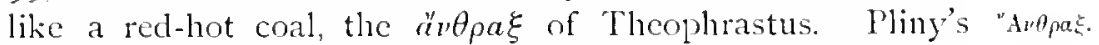
method of classifying gems according to their colour makes it specially difficult to be certain what stone he is describing in eacli case.

The same gem has frequently many different colours; and very different gems have almost the same tint in some cases. Thus, for cxample, the pure crystalline form of corundum may be bluc, red, yellow or colourless, giving to the gem the names respectively of sopphirc, mly, Orimtal topas and white sapplire. Again the mly and the carlnuncle may be of almost exactly the same tint.

EMERr, oucpes, Nuxim, is an impure semi-crystalline varicty of cormanm, of which the ruby and sapphire are the purer crystalline forms. That from the island of Naxos was

1 Cellini in his Trattato dith Orifforit, published in Florence in $1: 08$, cap. i. grives the following value for fine stones of one carat weight; mbl, Soo golul scmli;

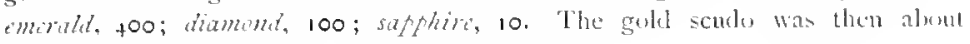
equal in purchasing value to a molem sovereign. 
Nitrum. considered the best, hence the name which Pliny gives it (H. N. xxxr. 5.4) "signis e marmore poliendis gemmisque ctiam scalpendis atque limandis Noximm diu placuit ante alia"; see also $\Pi$. N. xxxviı. Iog.

Its use for gem-engraving is mentioned above at page Io4. Another varicty of commlum from Cyprus, called Cyprimm, was used for grinding down and polishing gems - "ita vocantur cotes in Cypro insula genitae"; Hist. Nat. xxxvi. 54.

Emirald. Ener.uld, oriparoos; Theophrastus, Lap. 23; and Pliny H. N. xxivili. 62 to 75 .

In point of value Pliny ranks the cmerald third; the adamas coming first, and the porr (margarita) second.

Relief to the cyes.

l'liny tells us $\left(\$ \sigma_{3}\right)$ that the green of the cmerald is so refreshing to the eyes that gem-engravers were in the habit of keeping an emcrald by them to look at, as a rest for their eyes during the intervals of their trying labour ${ }^{1}$. Pliny also states (\$64) that the Emperor Nero used an emerald in some way to help him to see the gladiatorial fights - "gladiatorum pugnas spectabat in smaragdo"; but it is difficult to understand what is the precise meaning of Pliny's phrase. Judging from the context the emerald was used, not as a lens to look through, but as a mirror in which the scene was reflected. rartitis The emerald is the bright green variety of the beryl, which of bryl. consists of silicate of aluminium and glucina, crystallised in hexagonal form. The sea-green variety is the aquamarine of modern jewellers.

As Pliny mentions $(\$ 67)$, the emerald is specially liable to defects in the form of flaws and cloudiness; in fact a large and yet quite flawless emerald is never to be seen.

Pliny mentions a great many varictics of the smargalus, evidently including several different green stones under this name. Quoting Theophrastus (Lap. 23) he mentions ( $\$ 74$ Large and $\$ 75$ ) various columns and obelisks of considerable size, which were said to be made of smaragdus, but were more probably of green glass; as, for example, the column in the

\footnotetext{
1 In a previous passage (xxIx. $3^{8}$ ) Pliny says that a green scarabneus beetle was uset by gem-engravers for the same purpose- "gemmarum scalplores contuilu eorum (scaralneorum) acquiešcunl."
} 
Phoenician temple of Baal at Tyre, which is also described by Herodotus, II. 44. Pliny also tells us, on the authority of Apion, that in the great Egyptian labyrinth (in the Faym) there was a statue of Serapis made of smaragelus, which wats about fourteen feet high.

Antique gems on emerald are not common, but some fine examples do exist, dating from the time of the Roman Empire: as a rule, Pliny says, the emerald was worn unengraved, Hist. Vat. xxxil. 64. At $\$ 6$, however, he mentions a Greek emerald gem, engraved with a figure of Amymone, which was sold for four gold staters in the $4^{\text {th }}$ century B.C. (see above, page 40); but engraved emeralds of pre-Roman date are now almost, if not quite unknown. One of the finest examples of the use of the cmerald is a cameo of Medusa's head in the Devonshire collection, cut on a large stone, probably about the time of Hadrian.

Most of the ancient engraved emeralds which now exist are stones of poor quality, but Benvenuto Cellini tells us of one, dug up near Rome, which he bought from a peasant, Cellini"s imerallt. which must have been a stone of remarliable beauty: sec Cellini's Autobiogr. lib. 1. cap. 27.

This emerald was engraved with a dolphin's head, but it was chicfly valuable for the beauty of the stone. When set in a ring it was sold for a very high price, several hundred scudi, in modern value equal to as many pounds.

If engraved with an eagle or the scarabaeus bectle, the emerald was supposed to possess certain magical virtues; see Pliny, H. $\mathrm{T}$. xxxvil. 124.

Though the emerald was so rarely employed for the engraved gems of the Greeks, yet it was often used, chicfly for pendants, to decorate gold jewellery. Small cmeralds frequently occur in the form of necklace beads, mised with beads of amethyst and rock crystal, forming a most beautiful combination of colour.

In many cases these emeralds are not cut; the natural hexagonal form of the crystal is preserved, and nothing is done to the gem except that a hole is drilled through its axis for the insertion of the gold wire which holds it. 
Grick incralds.

Skill of anciont jeriellers.

$B_{t}{ }^{2} y /$.

Intion

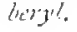

A very beautiful gold sceptre of the most claborate workmanship, in the gem-room of the British Museum, has its top formed in the shape of a flower with outer gold petals and a central boss, which consists of a large rounded cmerald or perhaps a paste-not fine in quality; but very beautiful and magnificent in effect. Nost of the emeralds used by the Greeks are very full of flaws, and would be despised by a tasteless modern jeweller, but, used with the wonderful skill and grood taste of an ancient gold-worker, they are as decorative in effect as if they were of the most flawless and costly kind.

The same remark may be made witl regard to all the jewellery of the Greeks, Etruscans and other classical races : the most beautiful results were gained by the old goldsmiths cren when they had to use sems which would now be rejected as valueless. A stone pale in colour and full of flaws, which would have little beauty if cut in facets, when cut in the old cabochon form and set in the exquisitely delicate pure gold-work of the ancient jewcllers becomes a gem of the highest decorative valuc. No modern art is in a more hopelessly degraded state than that of the jeweller.

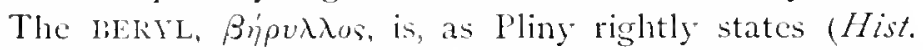
Nat. xxxvil. -6 to 791 , of the same nature as the emerald. As a jewel it was, he tells us, sometimes used uncut, the natural hexagonal faces of its crystal being simply polished.

The most valued varicty was the aquamarine - "qui viriditatem maris puri imitantur"; and next to that the chrysoberyl, chrysobernlli, of a brilliant golden tint and the chrysufrorsus, golden, but with a tinge of leck green.

According to Pliny (S $7 S$ ) the beryl was a specially favourite gem in India, where it was frequently worn, not set in gold, but perforated and strung upon an elephant's bristle. If the stone were of the finest quality it was not drilled, but was set between two bosses of gold: in which case, we are told, the Indians "preferred beryls of cylindrical form, rather than the usual shape used for gems." Like the cmerald, the boryl is usually not free from flaw's.

The Indians, Pliny tells us (\$ 79), had discovered a way 
to imitate various gems and especially the beryl by stainings rock crystal. This trick is still practised, especially by the German hapidaries, who lieat the crystal red hot, and then plunge it into a bath of cold dyeing matter. The sudden change of temperature fills the crystals with minute cracks into which the colouring matter soaks, and so stains cren the interior of the crystal, though in an imperfect and uneven way. Many other tricks of the lapidary were practised in ancient times, such as heating the pale ycllow topaz and thus changing its tint to pink. Onjacs and agates are imitated by first boiling inalectony" in loney and water, and then treating it with acid or with heat. The loney, which las soaked into the pores of the chalcdony to a certain depth, is permanently darkened by the acid; and thus a stone with layers of two different colours is formed. Sards can be turned into sartonyeres simply by laying the stone on a hot iron, thus forming a whitisli opaque layer on the heated surface.

Various tricks of this kind are mentioned by Pliny (I/ist. Net. xxxvil. 79, 98, 195, and 197): in the last passage he describes a different sort of fraud, still commonly used, the manufacture, that is, of a sordonyx, with beautifully even layers, by fastening together slices of three different stones. Another clever trick, which is still practised, is the backing a faste gem with a thin slice of genuine stone, so that a suspicious purchaser finds the back of the suspected paste will stand the test of a file without being scratched. The paste so treated is sold ready set in a ring, so that the junction of the true stone and the paste is concealed.

The beryl is not a common stone among aucient engraved gems even during the Roman period, but it is far less rare Ancicht than the sappline or emerald. The finest example known is the celebrated portrait of Julia by Euodos, now among the collection in the Bibliotheque of Paris; see page 74.

In tint this magnificent beryl approaches that of the aquamarine: it is a stone of special purity and most brilliant lustre, and was one of the most valued gems of the treasury. of the Abbey of St Denis. 
Biryl. As a rule antique engraved beryts are very pale in tint, often with a faint bluish tinge, but very pure and lustrous, so that the work on them has a specially beatiful effect when the gem is held up to the light, and the design seen by the transmitted rays.

carthande. The CARIIUNCLE or GARNET is one of the stones to which Pliny gives the name carbunahs: Hist. Nat. xxxvin. 92 to $9 S^{1}$. At present the name "carbuncle" is given to the gem when cut en cabochon or rouncled; if cut in facets it is the "garnet." This fine flame-coloured stone is a silicate of aluminium and calcium together with small quantities of iron, which give its colour; it varies in tint from a deep ruby red to a pale pink.

False Pliny remarlis (\$ 9S) that the carbuncle can be very carbuncli. successfully imitated in paste, but the imitations, like paste copies of other gems, can be distinguished by their inferior hardness-_." cote deprehenduntur, sicut aliae gemmae, fictis enim mollior materia fragilisque est"; the pastes also are lighter than the real stones, and are less cold to the touch, see Hist. Nat. xixvin. I 28.

The carbuncle is not an uncommon stone among the engraved gems of the Roman Imperial period, and it often bears very fine work. When found in its original setting it is frequently backed by gold or silver foil (brattea aurat a'd Foilet argenter) which much increases its beauty". As a rule the carlinele. surface of the carbuncle, where the design is cut, is convex. and in some cases the back of the gem is hollowed into a concave form, to give greater brilliance and transparency to the stone.

Gems of the Sasanian class are not uncommonly enarliuncles. graved on large and very fine Oriental carbuncles, probably' brought from India.

The carbuncle is also largely used for Greek and Etruscan jewellery. Gold necklaces, bracelets, ear-rings and the like are studded with plain cabochon-cut carbuncles backed with

1 The word carbunalus is also used to denote a red variely of sand (arma); see Vitruv. I1. vi. 6.

" On the ne of foilbacking, sce page nfo-11\%. 
brilliant gold-foil; the bright yellow of the surrounding gold and the deep red of the gem give a very effective and beautiful contrast of colour.

The gem-room of the British Museum contains some of the finest known examples of this elaborate kind of jewellery: many of them, from the Castellani collection, were found in litruscan tombs, but the most magnificent example came from Olbia in Sardinia ${ }^{1}$.

Oriental corbuncles are often of very great size. Pliny tells us (Hist. Nat. xxxril. 95) that drinking-cups holding one scutemins were sometimes cut out of an Indian carbuncle. Examples of such cups from India still cxist: the Hope collection of gems (now dispersed) contained a cup of considerable size hollowed out of a carbuncle of great beaty, and another is preserved in the Mayer collection in Liverpool.

1 Small pieces of garnet cut into thin slices and hacked wilh gohl foil are very commonly used in the chivonne jewellery of sason and uther Teutonic races. 


\section{CHAPTER XII.}

\section{MATERIALS USEI) FOK GLMS (continued).}

Silion sims.

Quarts c) $1 / a l$.

Gems of the Silicon fomily.

By far the greater number of antique gems, especially those of pre-Roman times, are engraved on some one of the many forms of silicon which exist in great abundance in almost every part of the world. The most familiar examples of this mineral are rock crystul or quertis, a pure form of siliza or oxide of silicon, and common flint, which is the same substance in an amurphous form, coloured by various slight impurities, especially oxide of iron.

These silicon stones are specially suited to the gemengraver on account of their toughness, absence of grain, and sufficient but not excessive hardness, which makes them comparatively easy to work, and at the same time but little liable to injury from wear or fracture.

The silicon minerals may be divided into the threc following classes according to their structure-

I. CKTstalline stones: such as colourless rock or quartz crystal, sometimes known as Brighton or Irish diamonds and other similar names. Slight traces of metallic oxides give various colours to quartz crystal, which is then known by different names, according to its tint: purple crystals are called amethyst, pale yellow is citrinc, orange yellow Caimsorm or Siotch topaz, leck green is called frase: other varieties are called rose quarts or smoky quarts according to their colour.

Aicuturine is quartz crystal filled with minute specks of mica, looking like gold dust. 
11. CRYPTO-CRYstaline or Morfious: the most important varieties of this class are sard, carmelian, chalcateny, jespir, blontstone, hiliotropi, plasma, and opal.

1II. STRATIFIED stones: this class includes all the varictics of agate, ony, sordonj'x and nicolo.

1. ROCK CRYSTAL is the purest form of silia, $\mathrm{SiO}_{z}$; its

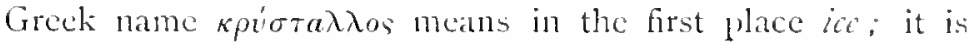
only used by late writers (c.g. Strabo, p. 717) to mean irystal.

According to Pliny (Hist. Nat. xxivit. 23) rock crystal is simply a form of ice, which has been permanently frozen by excessive cold, and is only found where there is abundanec of rain-water and snow; hence, he silys, it is abundant in the Alps. Nevertheless l'liny mentions various places, such as Cyprus, where snow and extreme cold are little known, as being among the principal sources of erystal. The largest block of crystal known to Pliny was one weighing about i 50 pounds, which was dedicated by Livia Augusta in the temple of Capitoline Jupiter in kome. In modern times much larger blocks of crystal have been found; one in the Museum at Milan weighs no less than 870 pounds

Cups and other ressels cut out of large blocks of crystal were specially valued by the Romans of the Empire.

I'liny mentions (H. N. xxxill. 29) at single bowl for which I 50,000 sesteres were paid by a Roman lady; and Nero, in his last moments of despair, shattered to pieces two crystal cylics, in order that no one else might possess them.

The coldness of crystal, Pliny tells us (\$ 30), made it specially suitable for iced drinks; while cups of amber were best for warm drinlis, and mominc cups were equally suitable for both. One curious use of erystal is mentioned by l'liny (\$ 2S): who says that a crystal ball, used as a burning glass, is the best instrument for surgical cautery:

In some cases, under the later Empire, crystal was used for the nude parts of sculpture on a large scalc, such as the face and hands, in spite of its being remarkably unsuited for such a purpose.

1 Murhina was probalily the beatiful purple tranlucent fom of thor spar, known in Lerbyshire, where it is largely found, by the name of "lilue John." 
Cosilal siminture.

Ciystal gems.

Ilati $I$.

Amethyst.

Whalerat.

fragment of a crystal hand from some life-sized statue. The translucent obsitim, a natural glass of volcanic origin, was also used in the same way by late Roman sculptors.

Under the Byzantine Emperors crystal vases of great beauty were made, cspecially wine-jugs, covered externally with decorative foliage and animals in relief'.

In carly times rock crystal was not unfrequently used for signets, especially for the cylinders and cones of Assyria and Babylon.

Crystal also occurs among the lenticular so-called "Island gems," and occasionally among sems of the finest period. The Fitzwilliam Museum (Catcrlogm, No. 5) possesses a very finc scarabacoid gem of about 500 1..C. with a warrior putting on his greaves, cut in the purest and most brilliant crystal.

Among Greek gems of a later period rock crystal is not common, but under the later Roman Empire, especially during the th $^{\text {th }}$ and 5 th centuries A.D., it is frequently used for large coarsely cut intaglios, probably intended, not for signets, but for decorative purposes.

It is also sometimes used for the large heads in relief which ornamented the fhaldrat on the cuirass of the Emperor or some high official; see Suet. Aug. 25.

The AuETHYst, a purple variety of rock crystal, is the

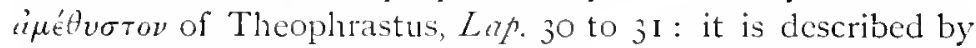
Pliny, ltist. Vat. xxxir. I 1 to 124. Its name was derived from the supposed power of this gem to enable its wearer to drinli freely without the usual conscquences ( $a$ frit. and

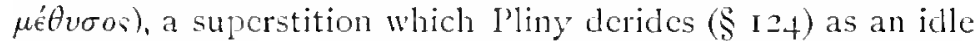
invention of the Magi. For Greek gems of the best periods amethyst was rery rarely used, but it is not an uncommon stone for gems of the Roman period; it is also sometimes used for Assyrian cylinders, and early scarab gems.

Phaterac cameo heads of the Imperial period are often cut out of large amethysts, and are very magnificent in effect.

1 Examples of these crystal jugs, almost identical in design, dating probably from the Sth or ght century A. I., are to be seen in the South Fensington Mluseum, the Bargello 1 luseum in Flurence, and in the Treasury of St Mark at Venice. 
Like the carbuncle, its effect is best when the stone is cut Amithyt. in a convex form (cm catrochon) and is set with a backings of highly polished metallic foil.

The amethyst varies very much in depth of colour, ranging from the deepest to the palest tint of purple; antique scms are usually cut on one of the pate varictics. In carly jewellery the amethyst is largely used, especially for necklace beads of various forms.

Rock crystal of other colours was sometimes used by the Romans for engraved gems, especially the yellow citrinc, of which No. 29 among the Fitzwilliam gems is an example. It is probubly the chrysolithus of Pling, H.N. xxxil. I 26.

The prase is not uncommon, the preasizs of Pliny (Hist. Prasi.

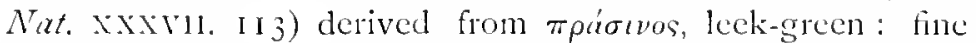
specimens are very beautiful in colour, and often bear rood work of the Imperial period, especially portrait heads of Emperors and Empresses.

II. Among the sccond class of silicon gems, those which are crypto-crystalline in structure, by far the most common as a material for ancient gems is the siRD).

As Pliny says (Hist. Vert. xxxvir. I06), "nec fuit alia gemma apud antiquos usu frequentior."

The sard, the oipdeon of Theophrastus, Lap. 30 (Latin sarda) is described by Pliny, H. N. xxxrir. ro5 and ro6. According to hin it was so called from being largely found near Sardes in Lydia; but it is more probable that it is derived from a Persian word meaning 'yellow.'

The sart varies in colour from a pale golden yellow to a reddish orange: the name corndian is frequently given to a class of gems identical in chemical composition and closely resembling the sard, but which are less perfectly transparent and of a deeper red in colour.

In point of structure the sard differs from the camelian in several respects: it is both tougher and harder and its fracture shows a slightly crystalline structure, while the comalian is more completely amorphous and its fractured surface is more smooth and gristening than that of the sarl, in that respect approaching nearer to chalcidony. 
bicinty' of saril.

Ear?y use of siril.

Chalie-

diny.

Ilati I.

Fasper.

No gem shows the engraving on it, when held up to the light, to as much advantage as cloes a fine sard.

The best examples are brilliantly transparent, and very fine in colour: perhaps the most beautiful are those which are of a golden yellow tint.

Both the sard and the carnelian are very commonly used for engraved gems of all periods, including the cylinders of Assyria, and the scarabs of the lhoenicians, the carly Greeks and the Etruscans. According to Pliny, signets made of sard, as well as those of sardony $x$, had the advantage that the wax did not adhere to them when an impression was made: see H. $N$. xxxir. 104 and 105 . He also tells us that certain linds of sard were usually backed with gold or silver foil.

According to Theophrastus (Lap. 30) the sard was of two principal kinds; the female, of transparent red tint, and the male, of a brownish colour.

Surdoin: The latter is now commonly linown as the sardoine; it is sometimes very dark in tint, almost black, unless it is held up to the light, when it appears of a deep translucent red. It occurs more commonly among Roman than anong Greck engraved grems.

Cilalcenoxy was also a rery favourite stone for gemengravers of all periods, especially those of early times. The most beautiful sort of chalcudony is of a semi-translucent milky white or pale blue tint; fine examples of the latter are called sapplivine chaliedony: gems No. 7 and I I in the Fitzwilliam collection are good examples of this quality of stone. Other kinds of chalcedony are of a translucent brown tint, such as No. Io in the same catalogue. Other colours occur, but all specimens of chalculony are to some extent translucent. If quite opaque the stone would come under the head of one of the varicties of jasper.

JASIER, $\ddot{\alpha} \sigma \pi / s$, is an almost equally common material for antipue signets, especially the Assyrian cylinders and the carly lonticular and scarab gems. It is also common among gems of the later Roman Empire.

The iaspis of Pliny (liist. Nat. Axxir. I I 5) denotes specially the green varietics of jaspor, and includes the trans- 
lucent kind which is now known as flasma-"viret et saepe tralucet iaspis." Pliny tells us that one fine variety of jasper was called $\sigma \phi p a \gamma i s$, as being $\kappa a \tau^{\prime} \epsilon^{\prime} \xi_{0} \chi \eta^{\prime} \nu^{\prime}$ the signet-stone; see H. . X.XXYi. I 7 .

Jasper signets of the fincst quality, he says, were set open in rings; that is, they were not backed with gold, but merely framed in a gold border- "praestantiores funda cluduntur ut sint patentes ab utraque parte, nec praeter margines quicquam auro amplectente." The meaning of the word fundu ( $\sigma \phi \in \boldsymbol{u}^{-}$ Són' $)$ has been explained above, see page 34 .

The jasper used for gems is most commonly either the green or the red variety, but it also occurs of many other Colours of juster. colours, ycllow, brown, grey, white and black. The black jaspir, known as Lydizn stone, was used by goldsmiths as a touch-stone, coticula, to show the quality of gold by the colour of its streak marked upon the stone: sce Pliny, Hist. Nat. xxxill. I26. The red jasper appears to be what Pliny in one passage calls hacmatites (Hist. Nat. Xxxvir. 169); but he elsewhere uses the same word for what is now called red lacmatite, an oxide of iron; see $H$. N. xxivi. I 29.

The red jasper used for cylinders and gems is frequently of the most brilliant blood-red tint. In Roman times it was belicved to have occult virtues, especially when engraved with a figure of Serapis or some other Egyptian or Persian deity. As Pliny tells us "Totus oriens pro amuleto gestare eas traditur," H. N. XXxril. I 8 . The same magical qualities were also attributed to the green jasper, on which figures of Horus or Harpocrates were frequently engraved during the Imperial period: see gems No. 20 and 105 in the Fitzwilliam Catalogue.

The iasfony, mentioned by Pliny in the last named passage, was a stratificd onyx, in which one of the layers resembled jasper: just as the sartony was a combination of the ony'x and the sard.

The plasma, as is mentioned above, is a translucent varicty of the green jasper: the word plasmer is a corruption of prasina, leck-green.

Roman Imperial gems of rery good workmanship some- 
Plasma. times occur on plasma of a beautiful emerald tint, usually mottled with markings of a deeper green: one of remarkable beauty in the British Museum is engraved with a bust of Severus, very well cxecuted considering its late date, and of very fine colour: No. I627, Brit. Mus. Cat.

Bloodstone. The BLOODSTONE is a variety of grean jerspor, studded with speclis of red, like drops of blood.

Akin to this is the inelotroplua of Pliny (Hist. Nat. xxxvin. 165) which is a variety of translucent green plasma with similar crimson spots, "porraceo colore, sanguineis venis distincta."

Both these stones were used by the late Roman gemengravers, but not very commonly. Among the Greeks they were scarcely cver used for signet-stones.

opal. The OPAL is a very beautiful form of silica, which derives its masnificent colours, not from the presence of any pigment, but from its laminated structure, which gives brilliant prismatic colours by breaking up the rays of light. The opal is described by Pliny ( $H$. $V$. xxxvi. So to 84 ) as being next in Ialue of value to the cmarald. Enormous prices were paid by the opal. Romans of the Empire for fine specimens of this gem. A large opal, mentioned by Pliny as being ralued at two million sesterces, was the cause of its owner the Senator Nonius being proscribed and driven into cxile by Marc Antony who coveted the possession of the gem. Though very beautiful as a jewel, the opal was quite unsuited to receive engraving, and was not used for signets, though there are a few Roman examples of its use for cameos.

III. Among the third the stratificd class of silicon stones, the most important are the following -

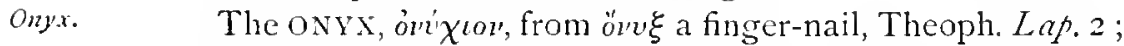
and Pliny, Hist. Nat. xxxvil. go to 91. According to Sudines, quoted by Pliny, its name was derived from the fact that the ony $x$ had one stratum resembling the human finger-nail, combined with one or more layers coloured like sard or jasper.

It should be observed that the word ony'x is also used by Pliny to mean a quite different substance, namely Oricntal alabaster; see Hist. Nat. xxxvi. 59 to 6I. 
Under the Roman Empire the onyx was a very favourite stone for signets, although an unstratified gem is really more suited for intaglio work. In the number and colour of its layers the onyx varies very much; like other stratified gems it was well suited for cameos, especially if it consisted of one white stratum on a brown or dark red one: the figures, being cut in the upper layer, appear in white on a dark background with very good effect, if skilfully treated.

As a rule the stratified forms of silica occur in nodules with more or less concentric layers formed round a nucleus, and it was therefore by no means easy for the gen-engraver to get hold of a sufficiently large piece with fairly level strata. In some cases large cameos were built up by joining together several pieces of onyx, as is the case with the celebrated Odescalchi cameo, six inches high by five wide, with busts of a Roman Emperor and his wife, or Mars and Roma. In this case the junctions are cleverly arranged so as to be concealed by the edges of dress, armour or necklaces ${ }^{1}$.

The word AGATE is now used in a rather vague way to dsati. denote almost any chalcadonic stone with strongly marked layers of deposit.

According to Pliny the achates (ix $\chi^{\text {i }} \eta \eta$ s) was once highly. valued, but in his time had fallen greatly in value. Its name was derived from the river Achates in Sicily, where fine specimens of it were found: Hist. Nat. xxxvil. I 39.

Pliny mentions a great many different varieties of agate, each with its special name descriptive of the marlings on it, such as iaspachatcs, smaragutachates, hacmachates, dentrachates and the like.

Most of these stones, according to the Magi, had some occult virtuc.

A variety of onyx, which was much used under the Roman Empire, is the nicolo as it is now called - a corruption of the Italian diminutive of onyx, onycolo. It has a bluish white layer on a dark brown ground. This is probably the Egyptian

1 The Odescalchi cameo is now in the IIermitage Museum at St I'etersburg: it was formerly taken for a work of Ptolemaic date. 
gem called Acgyptilla by Pliny (H. N. xxxvil. 148), who describes it as being formed "in nigra radice, cacrulea facie."

Sardonyx. The SARDONYx was the most highly valued form of ony $x$; it is described by Pliny, Hist. Nat. xxxvil. 85 to 89 .

The name $\sigma a \rho \delta \delta^{\prime} v \xi$, sardonyches, was derived from the stone having one layer like a sard superimposed on the strata of an ordinary onyx.

Thus, the true sardony may consist of strata of various numbers and colours, the essential point being that one of these layers should be of the colour and appearance of a sard.

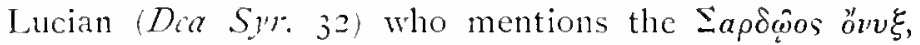
"Sardinian onyx," was probably misled by not understanding the real meaning of $\sigma a \rho \delta \delta^{\prime} v \xi$.

One of the earliest instances of this gem being named by any Greck writer is in Plato's Phacdo, I $10 \mathrm{D}$, where reference is made to the fine colours of merald, sardony and jasper.

According to Pliny (Hist. Nat. xxxvil. S8) the sardonyx, like the sard, is onc of the very few gems to which the wax does not adhere when it is used as a signet.

Sardanyer biads.

Tillue of gims.
The finest kinds of sardonyx and of onyx were imported from Arabia and India, where, as Pliny tells us, this stone was commonly drilled by the natives, and worn, in the form of beads or cylinders, round the neck.

Antique gems, especially large Roman cameos, often have remains of a drilled hole through them ; no doubt on account of the use of the stone on a necllace, before it came into the hands of the Roman engraver.

The sardonyx was but little used for Greek gems; like all stratified stones it is more suited for cameos than for signets. The Romans however used it commonly for both purposes.

Demostratus, quoted by Pliny (Hist. Nat. Xxxir. 85), tells us that Scipio Africanus the Elder was the first Roman who used the sardonyx for his signet, and that ever since that time it was very highly valued in Rome, coming next to the opal in point of costliness.

Pliny arranges the principal gems in the following order of value-I, Adamas; 2, Pearl; 3, Emerald; 4, Opal; 5. Sardonly. This howerer refers, not to their value for 
engraving, but as decorative jewels. As stones to engrave upon, the sart and the sermomis would probably rank first.

The importance of the sardony $x$ as a signet-gem is mentioned by Juvenal (Sat. xill. I $3^{8}$ ),

Sardenyx

"arguit ipsorum quos littera gemmaque princeps sardonychum, loculis quae custoditur eburnis:"

See also Juvenal, Sat. VII. 145

"Ideo conducta Paullus agebat sardonyche."

The Emperor Claudius made the sardonyx specially fashionable, that and the enerald being his favourite gems.

This concludes the list of Silion gems.

The Topazus of Pliny (Hist. Nat. xxivil. rof to 109) is certainly not the brilliant yellow gem which is now called the topaz. Pliny's topasus was a green stone, often of large size, and soft enough to be cut with the fite and to be injured by wear: \$ 109. Possibly under this name Pliny includes the modern chrysoliti and the providot, a gem of a fine yellowishgreen tint.

The statue, six feet high, made of topa wls, which, according to Pliny, was dedicated in honour of Arsinoe, the wife of Ptolemy Philadelphus, in the "Golden Temple" in Egypt, was probably an instance of the use of paste or glass, like the "emerald" column in the Tyrian temple of Baal. It is however doubtful whether the name topasus was not sometimes used for an opaque stone, since Pliny speaks of the green turquoise as closely resembling it.

The CALLAINA of Pliny (Hist. Nat. Xxirvir. I Io to I 2 ) appears to be the green variety of the turquoise.

Grontur. quecoise.

The finest examples are said to be of an emerald colour. It was specially found in the Caucasus, and in Persia, where it is still very largely used for decorative purposes.

Pliny remarks that the callaina is injured by contact with oil, a fact that is true with regard to all turquoises. It is, he say's, improved by being set in gold more than any other stone, and is easily counterfeited in paste.

The blue turquoise is evidently the stone which Pliny calls callais. 
Dlui tur pioise.

Turutoise iancers.

Lafis
lasuli.

Cyezros.

Caldais (Hist. Net. xxxvil. 151)-"callais sappirum imitatur," that is, it resembles lapis lasuli in colour.

The turquoise is a hyclrated phosphate of alumina, which derives its splendid blue or green colour chicfly from copper, but also from iron or manganese: it does not occur in a crystalline form, but is as hard as feldspar and takes a very high polish.

It appears not to have been used for Greek gems, but some fine cameos of Roman Imperial date are cut in it.

A very good example is No. 403 in the Marlborough collection, with heads of Livia and the young Tiberius cut in relief in a large green turquise, which seems to have been valued by the Romans more than the blue variety. Probably the only ancient intaglios of turquoise are of Sasanian workmanship.

The sappinus of Pliny (Hist. Nat. xxxyil. I20) is not what is now called the supthire, but is the opaque lafis la auli, from which the fine ultramarine blue used in painting was manufactured.

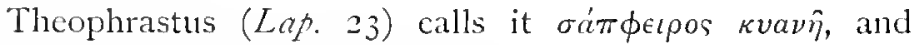
describes it as being speckled with gold.

Lapis lawuli is a compound mineral of the Hariznite class, consisting of a silicate and sulphate of calcium, sodium and aluminium. It is of a magnificent deep blue colour usually mottled with white, and contains gold-like specks of iron pyrites.

It appears also to have been known by the name cyanos (kúavos). Pliny describes gyants as being called "a colore caeruleo," and mentions its gold specks-inest ei aliquando et aureus pulvis qualis sappiris"; H. N. xxxvil. I 19.

Theophrastus (Lap. 55) mentions natural and artificial кiavos. The former came specially from Scythia and from Cyprus: the artificial kind was a product of Egypt, where it was invented at a very early period. Theophrastus also records that a certain quantity of kvaros formed part of the annual tribute paid by the Phoenicians: see also Pliny, Hist. Nat. xixvil. II9.

Many examples still exist of Egyptian scarabs and signets 
of other forms made of this artificial granos, which is an alkaline silicate, coloured a deep bluc with carbonate of Artificial copper: the same compound was used as a pigment from very carly times, as for example in the paintings of Egypt and those at Mycenae and Tiryns.

In Camiros and clsewhere in Rhodes and other Greck islands signets of this artificial cyonos have been found in the shape of rams' and lions' heads, pierced for suspension, with the signet-device cut on the flat underside. This artificial cyonos, when used as a pigment, is called caculium by Pliny; H. N. Xxxin. I6I, who says that the best quality came from Egypt, where it had been invented by one of the kings.

The real suppirus or lapis lexuli was not unfrequently used for Egyptian scarabs and for Assyrian cylinders.

During the Greek period, except in Egypt under the Ptolenics, it was rarcly used by gem-engravers, but it was not uncommon for the gems of the Roman Empire.

A good many well-cut intugglios and camcos in sappirus, of late Roman workmanship, still cxist, though it is not really suited for the purpose of signcts, on account of its inferior hardness and the great difficulty of finding a picce that is homogencous in colour, most lapis lazuli having its decp blue much broken up by whitc.

Pliny refers to this when he says it is "inutilis scalpturis intervenientibus crystallinis centris," Hist. Nat. xxxir. 120. Sasanian gems are occasionally cut upon very fine pieces of Persian lapis la ulli.

MLGNETITE (Latin magnes) is a hard metallic oxide of Mhatsetite. iron, $\mathrm{FeOFe}_{2} \mathrm{O}_{3}$, almost black in colour, with a strong metallic lustre when polished. It frequently has the power of attracting iron and then is known as natural locedstonc.

According to Pliny, who describes the magnes (Hist. Nat. Xxxvi. 126 to 128), it was called by the Greeks sideritis, from its power of attracting iron, oidnpos; the name magres, according to Nicander, was derived from a shepherd called Magnes, who accidentally discovered it by feeling the iron nails in his boots stick to the stones on which he was walking.

HAEMATITE is another ore of iron, a sesqui-oxide, very

Haimatiti. 
Hoimatice. similar to magnetite except that it is of a deep red tint like blood, and does not attract iron; it is described by Pliny (Hist. Nat. Xxxvi. 129) ${ }^{1}$.

Ha'matite, finely powdered, was used by the gem-engravers to give the final polish to their work. It was also largely used for medicinal purposes.

Early signets.

Magnotiti and hawmatite are both used very frequently for Assyrian cylinders, for the so-called Hittite gems, and for other signets of an early period.

Among the later Grecks these stones were rarely used, but they are not uncommon among the gems of the later Roman Empire. Fine specimens are very hard and close in grain, and have, when polished, almost the lustre and colour of stecl. Both magnctite and luamatiti sometimes occur in the form of crystals.

Magntite was also used for necklace beads and similar decorative purposes by the Egyptians, Phoenicians and other early Oriental races.

Stutiti. STEATITE, or soapstone, is a silicate of magnesia ; though not ranking among the hard stones usually used for ancient gems, it was an important material in early times. It was specially used for Egyptian scarabs, and not unfrequently for Assyrian cylinders and signets of the "Hittite," Phoenician and early lenticular classes. The softness of steatite, and the consequent ease with which it was worked, made it a favourite material for early races who had no harder substance to engrave with than flint or obsidian. For the same reason serpentine and limestones of various colours were commonly used for the primitive "Hittite" gems.

Graniti. GRANITES and BASALTS of various colours were occasionally used for some of the same early classes of signets for which the softer steatite was employed, especially for Egyptian scarabs and Oriental cylinders.

The very fine, hard greenish-grey basalt of Egypt was very suitable for a signet-stone, being very close in grain and

1 Pliny's use of the word haimatitis to mean rid jaspir is mentioned above, page 145 . 
even in texture. It was sometimes used for this purpose in liesalt. Egypt as late as the ptolemaic period.

Examples of the green basalt of Mt Taygetus being used for lenticular gems are mentioned above at page 20. This beautiful stone is an almost pure form of feldspar, coloured by a minute propertion of carbonate of copper ${ }^{1}$.

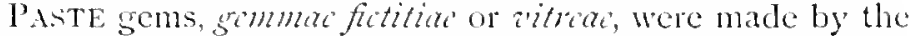
Greeks and Romans with very great skill. The material of which they were composed was a pure, hard glass, without any admixture of lead - what is now called "flint glass," a pure alcaline silicate with the addition of lime. Roman pastes usually contain, in 100 parts, about 70 of silica, i $S$ of soda, 8 of lime, 2 of alumina, and small guantitics of motallic oxites, to which the colour is due. Modern pastes are usually made with nearly 50 per cent. of oxide of lead; and they are therefore much softer and more liable to decomposition than the old ones. A fragment of an antique paste will scratch a modern one, as easily as rock crystal will scratch flint glass.

The colours of ancient pastes are often very magnificent, especially the ruby red, the sapphire blue, the emerald green and the orange yellow. Ancient pastes in Italy are often bought by jewellers to sell, when cut in facets, as real gems. The chief pigments used to colour the ancient pastes were various metallic oxides and salts. Blue, green and ruby red were produced by different oxides and salts of copper.

Manganese produced an amethyst-purple. Another bluc was given by cobalt; yellow was produced by carbon.

Opaque white, used in making the white stratum of imitation onyx, was produced by oxide of tim. The various colours used for glass are mentioned by Pliny: Hist. Nat. Xххт. 198 .

Pliny gives directions for distinguishing between pastes and real gems (Hist. Not. Nxxvil. igs to 200); the chief of these tests depend on the superior hardness, weight and coldness of the true gems.

A splinter of obsidian (natural volcanic glass) or a file

1 On the precious stones of the Greeks and Romans see Cursi, Pictre anticlie, kone, $18+5$, PP. $268-292$. 
Testsfor will, he tells us, scratch a paste, but will not touch a real faste. stone: unfortunately, he goes on to say, dealers in gems (mangones gemmamm) usually will not allow purchasers to put their stones to the scratching test (limac probationem); and if they did, there was always the risk of deception by means of the slice of real stone fitted at the back of the paste; see above, page 137.

Another test, mentioned by Pliny, is the presence of air bubbles in the body of the paste: there are however some very fine examples of antique pastes, such as that in the Marlborough collection, described above at page $I I 6$, in which no bubbles are visible ${ }^{1}$.

Such pastes are very rare; in most cases a careful examination will detect minute bubbles in ancient imitations of gems, even though in colour and purity of "water" the paste may be quite equal to a fine example of a genuine stone. In fact, in point of richness and beauty of colour antique pastes are, on the whole, superior to the genuine stones which were used by the gem-engravers.

Colourless paste or glass was made to imitate rock-crystal, especially in the form of cups and bowls: these, Pliny says (Hist. Nat. xxxv1. 29), were imitated with wonderful skill, so that it was difficult to distinguish between the real crystal and the glass; yet, he remarks, the excellence of the imitations did nothing to diminish the price of the genuine crystal: see also Hist. Nat. xxxvi. I9s and 195: in the latter passage Iliny tells us that Nero paid no less than 6000 sesterces for two small cups of glass, probably examples of elaborate cutting with the lapidary's tools, such as those mentioned at page I IS.

Ambr. AMIER : a considerable section of Book xxxvil. (30 to 53 ) is devoted by Pliny to a description of amber, sucimum,

I A great deal of the smperior beanty of ancient glass is due to the presence of theae minute air-bulbles, each of which eatches the light and radiates it out from the lody of the glass, thus making it internally luninous, not merely transparent.

The alsence of air-bubbles in modem stained glass is one reason of its being so much less beautiful than the glass of mediaeval times, which has the same peculiarity as the pastes of the classical period. 
though it does not properly come under the head of precious Amir. stones, and was much too soft to engrave for use as a signet.

Roman finger-rings cut out of amber have occasionally been found, but these had an engraved gem or paste set in the bezel. It was also used for camcos, especially for those which were set in honorary flalerac, for drinking-cups and even for statuettes, for which large prices were given".

According to Pling (S $5 \mathrm{I}$ ) amber could be stained to imitate various gems, and more especially the amethyst.

Iis account of its origin is quite correct, /fist. Nat. xixir. 42 ; amber is a fossil gum, which has exuded from a tree of the pine tribe-an extinct conifer, which modern botanists call Pinites Sucinifir. The name sucinum was derived from sucus (arboris), "tree-sap."

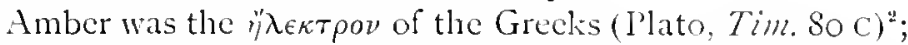
it was used in the early prehistoric period by almost all the races of Europe, and is found in tombs of the bronze and iron age over a very wide area. Homer (Od. Xv. 460 ) mentions a gold necklace, with pendants of amber, which was offered for sale to the Queen of Syra by a Phoenician trading-captain. Throughout the Greek period it was largely used as an ornament in all sorts of gold jewellery.

In Pliny's time amber necklaces were commonly worn by the women of the North of Italy beyond the river Po. The curious electric properties of amber are noticed by Pliny $(S+S)$, who speaks of it attracting, when rubbed, bits of chaff and straw, as the magnet attracts iron filings.

Nost of the amber used in Europe came from the shores of the Baltic, but it was also found in the Red Sea and in certain parts of the Mediterranean.

The existence of very carly trading routes from the North to the South of Europe is indicated by the frequent discovery of amber from the Baltic in the prehistoric tombs of various southern localities.

\footnotetext{
1 At Hist. Nat. xxxir. +9, Iling remarke that an amber statucte of a man often cost as much money as would have purchased a living slave.

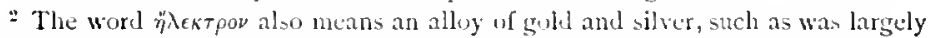
used for the early comages of Western Asia Minor, especially Lydia and Iunia.
} 
156

CHUICL OF STONES.

[CINH. XII.

I. vill-

rinm.

$\Lambda$ varicty of amber called lyncmimm is mentioned by I'liny, \$ 52: he says that it could be used for engraving like a $5 \mathrm{~cm}$, but that is probably in crror.

Chave of With regerd to the choice of special stones for the engravstemes. ing of certain subjects, it maty be observed that in Romam times and even among the later Greels stones of certatin colours were sometimes selected by the engraver with a refercnce to the subject he was about to cut on it.

Thus the gren beryl or aquemerrine wats considered suitable for nymphs or deitics of the sea, and the grece jorsfer for pastoral secnes, such ats cattle feceling.

Several of the epigrams on engrated gems in the Greck Antholegrie refer to this finess of colour and material to the subject cut on the stone.

Mersic

Other stones were selected for mystic religions reasons; rivitus. as, for eximple, the blood-red jeasper, which wats commonly used for heads and figures of the Gracco-Esyptian deities Scrapis and llorus.

It would not, however, be safe to press this point very far. It was probably quite an cxceptional thing for the colour of a gem to have any allusion to the subject which was engraved upon it. 


\section{TIE COMPARATIVE IIARDNESS OF GEMS.}

The following table indicates the different degrees of barluiss of the stones used for engraved gems, with the addition of some others for the sake of comparison. The number opposite each represents its hardness according to the scale now adopted by mincralogists generally.

I. talc, lowest degrec of hardness;

2. crystals of gypsum ;

21. ambir;

3. transfarint calciti and statite;

4. fluor-spar (murhina);

5 to 5 . lapis lawuli;

$5 \frac{1}{2}$ to 6 . opal;

6. turquisc, and fildsper such as grow bersalt and red porply'y';

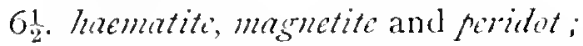

7. rock-crystal, including the coloured varictics, such as amethyst: the other varicties of the silicon $\mathrm{gems}$, such as chalcalony', sard and ony, are slightly less hard than the crystalline forms;

7 to $7 \frac{1}{2}$. carbuncle or sirmet;

$7: \bar{s}$. beyl in all forms, such as cmerald and the scagreen aquamarime;

8. topaz;

9. sapphive, mby and other crystalline forms of alumina;

10. diamond, the hardest of all known substances. 


\title{
APPENDIX.
}

\section{DESCRIPTIVE CATALOGUE \\ OF THE}

\section{ENGRAVED GEMS}

IN THE

FITZIVILLIAM MUSEUM, CAMBRIDGE

\author{
BY \\ J. HENRY MIDDLETON \\ IHRECTOR OF THE FITZWILIIAM MUSEUA, SLALE PROFESSOR OF FINE ART, \\ ANi) FELLOW OF KING'S CULLEGE, CAMBRIDGE
}

\section{CAMBRIDGE:}

AT THE UNIVERSITY IRESS.

I 89 I 


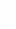




\section{CATALOGUE OF THE ENGRAVED GEMS IN THE FITZIVILLIAN MUSEUM ${ }^{3}$.}

I. Archaic glandular gem; stag with curred horns, rumning; below are two branches : rude archaic work on grem chalcitony, pierced lengthway's; date possibly Sth century B.C. or eren earlicr.

2. Eagle flying, holding a serpent in his beak and with Plate $I$. one claw; fine glandular gem, of gron chalculony, pierced; similar in type to No. I, but of better exccution; probably of the $z_{\text {th }}$ century I.C.

A similar cagle flying with a serpent in his beak occurs on various early silver coins of Chalcis in Euboea; see Zitschrift fir Numismatik, Vol. III. Pp. 2 I6 and 2 I7: and Numismatic Cluronicli for ISgo, l'l. III. No. 23.

The cagle and serpent is also a frequent type on coins of Elis of the 6th and 5 th centurics B.C.; see Head, Coins of the Ancients, Plate 14, Nos, 26 to 2S. The eagle bearing a serpent, hare or some other animal, was commonly regarded as an omen of victory sent by Zeus; sec Homer, /l. xir. 218. In his letter to the lligh l'riest Onias, Arcius King of Sparta states that his royal signet is an eagle bearing a serpent in its claws; sec Josephus, Ant. Fut. xil. 5. It was a common practice for the writer of a letter, both among the later Greeks and the Romans, to mention at the end of it, what

\footnotetext{
1 All are from Colonel Leake's collectim except Nos, $3,3^{*}, 4,8,+2$, and the Poniatewsigigem, the last in the Catalogue.

Unless described as canteus, all are intaglios.

II. 
was the design on its seal, as a guard against forgery and to prevent the letter from being tampered with in any way.

Ilate I.

3. Phocnician scarabatod of llate faste, surface corroded, found at Camiros in the island of Rhodes.

The design represents an intlened dity holding up a cup; behind is the knecling figure of a worshipper; in front is an Egyptian cartouche containing illegible hicroglyphs. This is a very characteristic example of Phoenician work, with figures of half Egyptian and half Assyrian type: given by I'rof. Middleton. Other paste scarabacoids of the same type from Camiros are now in the British Muscum, Nos. 140 and 141 in Mr Smith's Catalogue.

3 * Phoenician scarab of dark grecn jersper engraved with a design of Egyptian style, two seated figures of the hawkheaded deity Chonsu, also called Nefer-hetep, each holding a lotus-tipped sceptre, between them is the sacred Egyptian asp; above is the winged sun-disc, emblem of the god Ra. This is a good typical example of a Phoenician signet of the

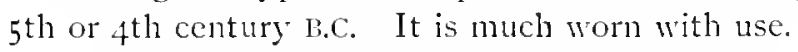

Plate 1. 4. Scarab of Phocnician style in red agate, the underside engraved with the sacred beetle of Egypt with outspread wings, within a "cable border." In the field is the inscription, in letters of the 5 th century R.C.-KPEONTI $\triangle A$ EMI, meaning "I am the signet or device $(\sigma \hat{\eta} \mu a)$ of Kreontidas." Examples of early gems with the names of owners are mentioned above at page $6 \%$. The inscription is not reversed, but is to be read on the gem itself, which may possibly be older than the date of Kreontidas; the style of cutting of the letters suggests that the name is an addition by a different hand from that of the original engraver of the scarab. This very interesting sem was discovered in I 8 to in a Greek tomb in the island of Aegina, probably the tomb of Kreontidas. It passed at once into the possession of Mr George Finlay, the well-known historian of mediacral and modern Greece, who described it in a paper published in the Bull. Inst. Corr. Arch. I840, pp. 140, 141. At his death it became the property of $\mathrm{Mr}$ IV. Ifinlay, who in 1877 bequeathed it by will to the Fitzwilliam Muscum. The device is a farourite one on Phoenician 
scarabs; Pliny, Hist. Nat. Xxivir. I 24, mentions the superstition that the scarabacus beetle, cngraved on an emerald, had certain magical virtues.

5. Scarabacoid, pierced: a Grek horo, nude, Wearing Hate l.

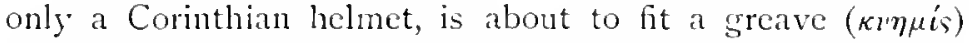
upon his leg. With both hands he bends the bronze apart; the Greck greaves having no means of fastening except the spring of the metal. This is well shown on the leg from a colossal bronze statuc, now in the British Museum, on which the bronze sreave is carefully represented, and modelled to imitate the muscles of the leg itself; sce four. Hell. Stut. Vol. vil. p. ISg and Plate LxIx. This very fine gem, of about 500 B.C., is remarkable for its spirited drawing and vory skilful treatment of the nude figurc. In style it resembles the pediment sculpture from the temple in Aegina.

It is surrounded by a "cable border," part of which has been ground away at some time, probably by a jeweller in setting the gem.

The stone is rock crystal of great purity and brilliance, possibly from Mount Taygetus in Laconia. Col. Leake obtained it in the Peloponnese. Gems of this period are rarely cut on colourless rock crystal, though it is often used for Assyrian cylinders, and sometimes for the carly lenticular gems. No. 435 in the British Museum has the same subject, though treated rather differently.

6. Fomali figure, wearing long chiton and himation, stands before a small altar of fire, holding in one hand a patera containing some offering, and in the other hand a small ocnochoe or wine jug. Fine Greek work of c. 4 So-450 1.C., or possibly archaistic work of later date, very minutely cut on a thin slice of bumt agate.

7. A mandess lion or lioness, which has sprung upon the back of a bull, and is fixing its teeth in the bull's shoulders; very fine Greck work of the 5 th century B.C., noble in style, broadly modelled and very spirited in desisn. A large scarabaeoid of fine saffilirine clatcedony, pierced for suspension.

In carly Greck art, that is from the pre-historic "Mycenae 
period" down to the 5 th century B.C., the lion occurs very" frequently; more especially on vases of the so-called "Oriental style" with encircling bands of animals. Bands with lions attacking bulls are very common. Herodotus, vil. i 26, tells us that certain districts of Thrace were full of lions and wild bulls, and in the previous section, vil. 125, he records that, during the Persian invasion of Thrace, many of the camels used as beasts of burlen in the army of Jerxes were killed by lions: cf. also Aristotle, Hist. Anim. vi. 3 I.

In later times the lion became extinet even in the mountainous regions of Thrace, and hence, probably, the reason of its becoming comparatively rare in Greek art. A somewhat similar design to that on this noble gem occurs on silver coins of the 6th century B.C. struck at the Thracian Acanthus; see Head, Coins of the Ancionts, Plate IV. 7.

The same subject, on a colossal scale, is repeated in more than one carly limestone (poros) group recently discovered on the Acropolis of Athens, and now preserved in the Acropolis Museum.

8. A con with head turned back towards its calf, which is sucking; a fine carly Greek design, similar to that on coins of the $5^{\text {th }}$ century struck at Dyrhachium in Illyria, and in the Island of Corcyra, during the 6 th and 5 th centuries E.C., and elsewhere. Large scarabacoid of almost colourless paste, pierced: the surface of the paste is corroded by decomposition.

In Oriental cults the cow and calf were frequently used as types of the Nature Goddess, Astarte, whom the early Greelis associated with Hera.

9. Head of Horakles, bearded, with short curly hair, apparently of the 4 th century B.C.

Large scarabaeoid in almost colourliss glass or paste, picred, like No. 8. Both these paste gems have been formed in the usual way by pressing a lump of hot, soft glass into a mould: the edges, back and ground of the front were then cut into shape on a lapidary's wheel.

This scarabaeoid and No. 8 were probably pendants of a necklace, as they are far too large for rings. 
10. A fouth, nude, leaning on a jagged staff, bends rate $/$. downwards to caress his dog, which looks up affectionately at his master; within a cable border. A gem of exceptionally beautiful design and workmanship, of the best period of Greck art, the midule or latter half of the 5 th century I.C. The modelling of the mule form is extremely skifful, and the details are most minutely worked. Gems of this date are very rare, especially examples as large and carefully executed as this. A scarabaeoid of clonded chataduny, of a yellowish brown tint, pierced.

The design on this remarkable gem is similar to that on some of the sepulchral stelere of Athens, dating a little before and after 400 I.C.; most of these are reliefs of life size or near it, and were found in the cemetery outside the Dipylon of Athens. Another gem with almost exactly the same desigrn, but slightly inferior workmanship, was found in a tomb in Cyprus by Cesnola, and is illustrated in his Cyprus, 1877 , Plate xxxix. No. 6.

Another subject which occurs on the Attic stilac is engraved on a gem in the British Museum (No. 473), which bears the nude figure of a youth, seated, and holding his oilflask ready for the bath.

I I. An Athonan lady, wearing the chiton foderes and Pate 1. its girdle with the himation across her knees and a veil over her head, is seated in a chair with lathe-turned legs; with one hand she raises a corner of her veil. In front of her stands an attendant girl, wearing the long chiton and over it the short chitonishos; she holds in one hand a weath, and in the other a mirror which she presents to her mistress. In the field at the top is the inscription MIKH lady's name; at the side, behind the seated fisure, in very minute letters, is the name $\triangle E \equiv A M E N O \Sigma$, the signature of the gem-engraver, cut so as to be read on the stone itself. A scarabaeoid of fine supphirine chalcetony", pierced; a "cable" border surrounds the whole design ; see above, page 68.

This gem is a very large and beautiful example of Athenian work of the $4^{\text {th }}$ century, probably before 350 I.C. Its design, like that of No. IO, is precisely the same as those on some 
sepulchral reliefs from the Dipylon Cemetery of Athens. Toilet scenes in one form or another are among the most frequently recurring subjects on the tomb-stelae of Attica. It may be that this beatiful gem was engraved and worn in memory of a dead wife or sister. In addition to its great beauty as a work of art and the comparatively large size of the composition, the fact of its being signed by the artist makes this gem one of the most important examples of the kind in the world. Genuine artists' signatures on gems are extremely rare, though forged ones are common enough, and it is a remarkable coincidence that two of the very few other gems, which, like this, have an artist's name of undoubted genuineness, are both signed with the same name Dexamenos; see Newton, Essaj's on Arhavolyzy, i 880, p. 396. One of these is a minutely executed representation of a crane flying, with the inscription in microscopic letters- $\triangle E=A M E N O \Sigma$ EMOIE XIOL, "Dexamenos of Chios made (me)." The other gem has a standing crane, with the name $\triangle E \equiv A M E N O \Sigma$ alone, as on the Fitzwilliam scarabaeoid.

Both these gems with cranes were found, together with other objects of Attic workmanship dating probably from the first half of the $f_{\text {th }}$ century B.C., in one of the numerous tombs which have been opened at Kertch in the Crimea, the ancient Panticapaetum. They are now in the Hermitage Museum at St Petersburg, and are illustrated in the Comptcromble da Commiss. Arch., I86I, Plate VI., No. Io; and ib. i $\$ 65$, Pl. III., No. 40.

The coincidence of date, the minute workmanship, and the close similarity of the letters in the inscriptions make it highly probable that both the gems from Kertch and that in the Fitzwilliam Muscum are the work of the same Chian artist. It is very improbable that there should have been at the same date more than one gem-engraver of the same name and of such exceptional ability as was the artist of the Fitzwilliam and the Kertch gems.

A fourth gem, with the signature $\triangle E \equiv A M E N O \Sigma$ EחOIE, exists in a private collection in Athens; it is a male bearded head apparentiy a portrait: see Compti-rendu de la Comm. 
Arch., I\$68, Plate I., No. I2: it is said to have been found at Kara in Attica, but its genuineness is doubtful. 1t was not known till after the discovery of the gems by Dexamenos in the Kertch cemetery, and its inscription may very possibly have been copied from the one with the flying crane. The Fitzwilliam scarabacoid, on the other hand, was in the possession of Colonel Leake long before the other gems of Dexamenos had been discovered, and its genuineness cannot be suspected.

On the various gems by Dexamenos, see Furtwängler, Fahbluch Arch. Inst., 1888 , p. 199 to 204.

12. A fimale figure, fully draped, stands talking with a

Plate 1 . nude youth, who leans upon his staff--possibly Electra and Orestes; of good Greek style, but carelcss workmanship, on a fine orangi sarl. In point of technique this gem is an interesting example of the extensive use of the diamondpoint, especially in the drapery of the female, and in the hair of both figures.

I3. Scarabacoid: a bull cualking: finc Greck work of the $5^{\text {th }}$ or $4^{\text {th }}$ century B.C. On a convex bluish white chalculony with brown patches.

I4. Bull standing; behind is a cow facing in the opposite Plate $I$. direction; well and minutely cxecuted on bandat chalcodony; possibly Greek work of the $4^{\text {th }}$ century B.C.

15. A true scarab in camalian, piered, the device on it is a Sirch, standing, playing on the double flutes. The Siren is represented as a human figure with bird's feet, tail and wings; a similar figure occurs on a curious four-lobed pendant $\mathrm{gem}$ in the British Museum, No. 549 in Mr A. II. Smith's Catalogue. Scarabs of this type are often found in Etruscan tombs, being cither Greek imports or native copies of Greek designs. Forgeries of modern date are also very common; the Fitzwilliam example may perhaps be one of these. It is set as a scal in a modern gold mount.

16. Man on horsebach, with spear, pursuing a stag with I'ate $/$. branching horns which is already wounded with another spcar. The hunter wears a curious hood over his head with horn-like projections at the back; the rest of his diess is not 
very distinct, but it appears to consist of trousers and a short tunic. He sits on a lare fringed saddle-cloth, and appears from his costume to be of semi-barbarian type, not unlike some of the figures of Scythians represented on objects of Greck workmanship found in the tombs of Kerteh. It is a well executed design, possibly of northern Greck workmanship. The horse closely resembles that on coins of various Macedonian kings.

This important gem is a large scarabacoid of clouded chalcalony, with agate layers at the back: it is pierced for suspension. Set in a modern seal-mount.

17. Fragment of a large and very fine gem with a profile mali head; only the back of the head with its crisp curls remains: probably of the $4^{\text {th }}$ century li.c.; engraved on sardony.r with a raised border in a white layer.

18. Fragment of a large gem of good later Greck style, probably 3 rd century B.C. The subject appears to be Pigrasus or some other winged horse trempling on a sipent, but only the front portion remains; the rider and most of the horse are wholly lost. Cut on a fine orange yellow serret.

Plate 1. 19. Artemis in long chiton, with scarf-like drapery floating behind her, is walking, holding a dead fawn by the foreleys, and in her other hand a bow and two arrows; she wears shoes tied with a knot above the ancle. Work of good style, probably copied from some statue of Praxitelean type, cut on a deep oretnge' sard.

Plate 1. 20. Horms (the Greck Harpocrates) seated on a lotus flower, with one finger pointing to his lips, and in the other hand a flail, on dark green jersfor. Good work of the Ptolemaic period of Egyptian style, probably of the $3 \mathrm{rd}$ century b.C. On the back, in much later characters, is rudely scratched the mystic word ABPACAE, added by some Gnostic owner.

The letters of $\alpha \beta p a \sigma \alpha \xi$ or $\alpha \beta p a \xi \alpha$ ' (as Greek numerals) make up the number 365. According to the Gnostic creed there were 365 orders of angels, each of which occupicd a separate heaven; each heaven being superior to the one below and inferior to the one above it. It was especially the followers of the Gnostic Basilicles who used this mystic word, 
denoting the whole Hierarchy of IIearen, and also the supreme Ruler of the universe. The Abrewers deity is frequently symbolised by a human figure with a cock's head and serpent legs; this type is intimately connected with the sumgod Mithras. The name and symbol of Abraxas were supposed to have great talismanic powers, protecting the wearer from disease, accident and misfortune generally. Its medical virtues, when cut on the right stone, were very hishly valued, and believed in for many centuries; to a great extent even throughout the mediacral period. See abore, page 123.

$2 \mathrm{I}$. Aphrodite, half nude, leaning against a short pillar; she holds a helmet in one hand, and a long staff or spear in the other; against the pillar a round shield is set. It is engraved with great delicacy and minuteness on black jersper. This figure, like No. I9, is probably taken from some celebrated Greek statue; the design occurs very frequently on gems; the collection in the Paris Bibliothèque contains no less than nineteen examples.

22. Eros, as a graceful winged youth, seated on a rock, holds up a wreath; his torch is stuck into the ground before him: fune Gracco-Roman work on sardoine, minutely executed with much taste and skill.

23. Apleroditi, fully draped in chiton and himation, stands leaning against a short pillar. In one hand she holds a bird, probably meant for a dove, with the other hand she raises a corner of her himation: very rucle work, mostly done with a coarse wheel, on a large, slightly striated camelian. This gem, though of very poor workmanship, is of interest as being probably a copy of some celebrated Greek statue.

24. Hunting scone in two tiers; at the top, a horseman, riding at full speed, aims an arrow at a lion which approaches him. Below, a similar horseman aims a long spear at a wild boar. Both of the hunters wear a tight tunic and trousers, and on their heads a hood of Oriental fashion. Instead of a saddle the horses have a large fringed cloth over their backs, and their long tails are tied up with a knot.

Persian work, of the Sasanian period, about the th $^{\text {th }}$ century A.W., on a large scarabaeoid of clondat chatiedony', pierced. 
25. Silmus mask, full face, of Greek workmanship, very minutely cut on nicolo: set in a modern ring, on which is engraved the word "Epirus," i.e. the district where Col. Leake bought the gem.

26. Enthroned figure of Fupiter, cxtending one hand over a small fire-altar; in the other hand he holds the long sceptre or hasta fura. Early Roman work on fine ofaline chalcodony": in a modern ring.

Nate H. 27. Fufity cnthonet holding in one hand the hasta pura, and in the other a small figure of Victory bearing a wreath: at his feet an eagle. Roman work on a carnclian, in modern ring setting.

This design, which is common on Roman gems and on the reverses of Imperial denarii is derived originally from the celebrated gold and ivory statue of Zcus at Olympia by Pheidias, which is copied on the reverses of various Greek coins, such as the tetraorachms of Alexander the Great.

28. Standing figure of Bacchus, nude, pouring wine from a cantharus to his panther; with the other hand he holds the thyrsus: rude Roman work.

This is a very common design on Gracco-Roman and Roman gems: e.g. two gems in the British Museum; Nos. 9.45 and 9.46 in Mr A. H. Smith's catalogue: Nos. 62 and 63 in the Fitzwilliam collection have the same subject. Striated, bluish chaladony, in modern setting.

29. IVingal Victory, half draped, resting one foot on a rock; she points to her face with one hand, and in the other holds a palm branch. Roman work on a fale tofas or citrine with both sides cut en cabochon. In modern ring setting.

30. Iringed Victory holding in one hand a wreath, and in the other a palm branch: rude Roman work, probably of Republican date, on a very fale sard: in modern ring setting.

Ilute II. 3I. IFinged Victory with wreath and palm branch, as on No. 3o. Roman work of the Republican period on fine chaliciony, in modern ring setting.

This fine gem much resembles the sard set in a gold ring, which was found in I 780 on the skelcton hand of Cornelius Lucius Scipio Barbatus, consul in 298 L.C., whose sarcophagus 
is in the Vatican. This ring passed into Lord Bererley's collection, and is now in the possession of the Dulic of Northumberland. It is of great value, not only from its historical interest, but also as being a dated example of carly Roman glyptic art, which helps to fix the period of other similar gems. See above, page 47.

32. Profile bust of Dimma with a crescent on her head, I'kat 11 . between busts of Castor and l'ollux, each with a star over his head. The Dioscuri weas the usual filus or egg-shaped cap' encircled by a wreath, and a chlamys over the shoulder; their heads are very similar to those on silver coins of Bruttii of the 3rd century B.C.; see Brit. Mus. Cat. of Greek Coins of Italy, No. S, p. 320 .

Fine sapphirine chalcedony, in modem seal setting inscribed "Morea," where Col. Leake bought it.

33. Minerer standing, wearing the long chiton and a helmet; she holds one hand extended, and in the other her spear and shield. Very good Roman work on a leep red camelian, in modern ring setting.

The original of this design appears to have been the Athene Parthenos of Pheidias: it is a common subject on Roman gems: the extended hand usually holds a statuette of Victory, which on this gem is omitted. The design seems copied, not directly from the statue, but from the representation on various Greek coins.

34. Nude figure of Bonus Eiventus, standing: with one hand he pours a libation on to a small fire-altar: in the other hand he holds two ears of wheat. Roman work of the first century A.D. on a nicolo-onyx. This design is common on reverses of Imperial denarii during the ist and 2nd century A.I. In a modern ring setting.

35. A chariot drawe by two ants: the driver is a rabbit, who holds the rein in one paw and a whip in the other. Roman work of early lmperial date, on a carmilian, in modern ring setting. This fanciful type of design occurs frequently on Roman gems, and also among the wall paintings of Pompcii, possibly in some cases with a satirical meaning.

36. Nude hero with crested helmet, and sword slung Plak $/ 1$. 
round him, kneeling on one knee; he works with a graver and hammer (?) on a metal cuirass. Rather coarse GraccoRoman work on a fine transparent dhalcidony. Acquired by Col. Leake in the Peloponnese. In modern ring setting, on which is engraved "Morea."

Mate 11. 37. Profile lust of Hirmes wearing a small petasus and chlamys fastence on the shoulder with a fibula; of good Greck style. Pastc, imitating orange sard: in modern scal setting.

38. Profile portsait of bardless yonth with long hair. In the style of good Roman work of carly Imperial date in fine rat jaspor. In modern seal setting; the gem itself may possibly be a modern copy.

39. Cameo heal of Midusa, very rude work in onyex of two layers; the back is roughly shaped by flaking off chips: in modern ring setting. The cameo also is perhaps modern.

40. l'ortions of two gold car-rings of very beautiful Greck workmanship: one is in the shape of a lion's head skilfully modelled: on the shank is a delicate scroll pattern formed in that minute sramulatit work, which the Greek jewellers exccuted with such wonderful skill. The other is a pendant, with a miniature figure of Eros, a marrel of minute exccution: it was acquired by Col. Leake at Pella. Gold ear-rings, with an exactly similar figure of Eros, were found by Cesnola in a tomb in Cyprus; sec Cesnola, Salaminia, I884, p. 4I, fig. 39 .

4I. Ring wholly in slass, probably of Greck workmanship: the bezel is of orange-yellow paste with a thin layer of white under it to imitate sardony ; the rest of the ring is of a pale purple paste. Obtained by Col. Leake in Thessaly.

42. Ring-shafiel bead of magnitite: on it is rudely cut it man driving a spear through a lion: Assyrian worls of early date. Given by Prof. Middleton; bought at Beyrout.

43. Large cameo head of Hore, wearing a stiphanus, in very high relief on an ony. of two layers, opaque white on a transparent chalcedony layer. Graeco-Roman work of good style, but coarse exccution, said to have been obtained by Captain Gcorge Keppell "near Kula." In his Norratia of a 
journey from India to England, 1827, Vol, II. p. 226, Captain Keppell mentions his visit to an eminence called Kula Noo, in Tartary, near the town of Kuba on the banks of the river Deli, which rises in the Caucasus and runs into the Caspian Sea; he does not, lowever, mention this cameo.

In modern gold setting inseribed "Ruins near Kula."

4t. Large ring, wholly of silwer, with large oval bezel on which is soldered in relief in gold letters the inscription ATTYAA E- probably the owner's name. This ring is clearly. of late date: Dr Waldstcin has suggested that it may possibly bear the name of Attila, the great general of the lluns and Goths, $43+-45+$ A.r. in spite of the spelling 'A $\tau \tau \dot{y} \lambda a s$ instead

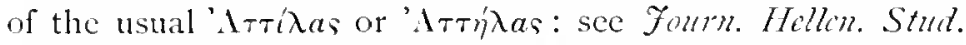
IV., p. I62. On the inside of the hoop some recent sacrilegious hand has ent the "ord "Thessaly" in large letters, a record of the district where it was bought by Col. Leake.

45. The goddess Roma, in stolu, fallium, and helmct, seated on a heap of armour, holding a spcar in one hand and in the other a small figure of Victory bearing a wreath. In the field behind, Q. MAX. cut so as to read on the gem itself. Early Roman work on carnelian. This common type of the goddess Roma is derived from the Greek Athene, as represented on such coins as the tetradrachms of Lysimachus struck c. 300 B.C., with the deified head of Alexander on the obverse. Mr King suggests in his Catalogue (Case I1., No. 2S) that this was the signet of the celebrated Quintus Fabius Maximus, one of the earliest Roman conquerors of the Grecks, but the name was too common for any certainty as to the ownership of this special gem.

46. A seated figure of Roma (like that on No. 45) with sword and spear, holding Victory in her outstretched hand. Coarse Roman work on an orange sert, decply cut.

47. Minute figure of Athene advancing, holding spear and shicld: orenge serd, a fine Greek design, which probably represents some important statuc.

48. Hars in short chiton and crested helmet stands, holding a spear in one land; with the other hand he supports a round shield, resting it on the ground. 
Bold Roman work on camclian, chipped on one side.

Ilak 1I. 49. Bust in profile of the winged I'ictory; behind her is a palm-branch. Very fine early Roman work on chaledony; chipped. The hair, wing and palm-branch are exccuted in a stiff but very delicate way with the diamond or corundum point: it is a very interesting example of the best sort of Roman work during the later Republican period. The same design occurs on several denarii of the Republic, and on the obverse of both sold and copper coins struck by Julius Caesar in 45 B.C., with the legond C. CAESAR DIC. TER.

Plate II. 50. Bust of Dianer in profile, with bow and quiver slung across her shoulder. Her chiton is fastened with a fibula on the shoulder. Round the head, in coarsely formed Greck letters, the owner's name $\Theta P E \Pi T O C$, cut so as to be read on the impression.

Good Gracco-Roman work on carnclian.

51. Female head in profile of the Amazon type; bchind is a double axe, in front the inscription FELICI $s . .$. , part broken away.

Fine Gracco-Roman work on srey jasper.

Plate $11 . \quad$ 52. Vonus Tictrix leaning against a cifpus, with drapery round the lower part of the body: in one hand she holds a hasta fure or long sceptre, and in the other hand a helmet. On the ground in front is a cuirass. Coarse Graeco-Roman work on a convex striated agate. This design is probably copied from some well-known Greek statue.

Flate II. 53. A comm-copiac, dolphin and tridint srouped crosswise in a very graceful way. Very fine Roman work of the time of the early Empire on a dull semi-opaque sard; possibly the symbol of some general who, like NI. Agrippa, was remarkable for success botll by sea and by land.

54. Nude figure of Gonjmali seated on a rock: he gives Jove's cagle drink out of a fatira. Graceful design, poorly exccuted on a small carnclian. It is probably a Roman copy of some fine Greek design.

That IT. 55. A Triton holding a trident, represented as a male figure with fish-tails in serpentine coils instead of legs. Good Roman work of carly Imperial date on a yellowish chalcidony. 
56. Cupit standing; in one hand a torch, with which he flat /I. singes a butterfly helel in the other hand: symbolical of the lot fever of love. A Roman design on very" fine red jasper.

The same design occurs among the "Marlborough Gems" (No. 142 in Mr Story-Maskelyne's Catalogue), and it is repeated on many other gems.

57. Minute figure of Fortuna standing, holding in one hand a cornu-copiae and in the other hand at rudder; a frequent design on Roman denarii of Imperial date. On reel jirsper.

58. Roma seated on a heap of armour: very rude Roman work on an orange sarl.

59. T'ulian seated, working with a hammer on a helmet placed on an anvil: very rude Roman work on mixed jasper and chaladony".

6o. Mercury standing with the caduccus in one hand, and in the other a purse and a cock: in the field is a scorpion and a goat. Rude Roman work on camclian. This is a not uncommon type of astrological gem, representing its owner's fortunate horoscope: cf. Merlborough Gems, No. 172 in StoryMaskelyne's Catalogue, London, 1870.

6r. Mercury standing, with the caduccus in one hand and a purse in the other: very rude Roman work on ycllow sart: a very common subject both for gems and for sculptured reliefs of the Imperial period.

62. Litchus with the thyrsus in one hand and in the other a cantharus: at his fcet a panther: rude Roman work on sard: cf. No. 28.

63. Minute figure of Backlus holding the thyrsus and a cantharus, with the panther at his feet (like No. 6z): the whole figure is enclosed by a vine. Poor Roman work on anctlyst, a stone which was supposed to give its wearer the power of drinking large quantities of wine without his becoming intoxicated: hence its name from $a-\mu e ́ \theta v \sigma o s$. Pliny (Hist. Nat. xxxir. 124) expresses his disbelief in this superstition.

Dionysiac subjects were very frequently engraved on the amethyst, especially during the Roman Imperial period.

64. IVinged figure of Nomesis in stola and fallizm, Phath. 
standing holding a caduceus over a conical object like the mete of a circus. The Romans liad no very fixed method of representing Nemesis: on gold and silver coins of Claudius, she is represented as a winged woman holding a caduceus, with a serpent on the ground. On other coins she appears with different symbols.

Very rude Roman work on a convex orange sart; the use of the drill-point and the wheel is very evident, owing to the want of skill of the engraver.

65. Portrat of Socrates, of the usual Silenus type, on comitian. Gracco-Ronan work, if not a modern imitation: broken across: in Mr King's Catalogue the fragments are numbered separately 12 and 46 in Case 1.

Plate II. 66. Profile portrait of Noro, laureated, executed in a fairly good, bold style on carnelian.

67. Very rude frofile head with radiated crown, perhaps representing Afollo Helios: coarsest kind of Roman work on camelian.

68. Heat of the jouthful Horulis, rudely worked, the hair exccuted with the drill-point. On red jasper, broken at the bottom.

69. Silmus seated on a rock, play's the lyre in front of a small shrine set on a rock: behind him is a wreath with long streaming fillets. Rude Roman work on orange sard. No. 993 in the British Museum has the same subject.

70. A goat standing under a tree: in the ficld, on the other side, is a lizard. Roman work, very well and delicately. executed on the convex surface of a sardony'x. A very remarkable example of minute worl:

71. A Faun seated on a crate or basket; in front of him is a goat, which he caresses with one hand: in the other hand he holds a river-rush. Delicate Roman work on sard. The same design occurs on a gem in the British Museum, No. 1056.

Plati II. 72. A hippocamp or sea-horse, swimming. Fine Roman work on a convex carnclian, deeply cut ; edge chipped.

Plate II. 73. A horse standing to graze; above it, a star within a crescent: very fine Roman work on carnclien. As Mr King 
suggests (Cat. P. It, No. 26) this may be the portrait of a falourite race-horse; the star and crescent being the owner's badge, which was frequently branded on the horse's skin.

74. A lion wabling under a tree, holding some object in its mouth. Very fine and minutely executed Roman work on white jerser mottled with pink; the colou has been altered by fire.

75. Hownd mming at full speed; in the field above is a curved knobbed stick, such as was used to knock over small game. Coarse Roman work on olive green flesmer.

76. Crablukling in its chass a sholl; very minute work on sord. This design occurs frequently on Roman gems: in some cases the crab holds a fish or a shrimp in its claws.

77. An ant, rudely cut on an eny'x of four layers.

78. A hound attaking a rabhit; above them is a flying eagle: rude Roman work on yolloa' jospor. The same subject occurs on many gems of Imperial date, e.g. One in the British Museum, No. 1958 in the Catalogue.

79. 1 cock, holding in its claw an ear of wheat; Roman work, cleverly exceuted on a very small irysoprase or flasmo of pale emerald green colour.

So. Cupid riting on a dolflin: coarse Roman work on camelian.

81. A saty and a goat on its hind legs, dancing face to face: behind the satyr is an ear of bearded wheat: Roman work on a surt. About a third of the gem is missing. The design is one which occurs in Pompeian paintings.

82. A welf or bitcle siating suck to an infant: above is an eagle with outspread wings. The animal resembles the "wolf of the Capitol" suckling Romulus and Remus: possibly one of the twins was omitted on the gem for want of space; or perhaps the subject is that which occurs on coins of Cydonia in Crete, having, on the obarese, the infant Miletus (the brother of Cydon the founder of Cydonia) suckled by a wolf. Rude Roman work on a fine surd.

83. The atgle of Fupitor standing with outspread wings. Coarse Roman work on a sardonger with roughly chipped back. 
84. A bull walking, on yellow paste, a cast of a good gem.

85. A winged male figure, nude, in crested helmet, armed with spear, sword and shield. Coarse work on a pale yellow sar"t: chipped.

S6. Cupit sitting on the ground with his hands bound behind him; a butterfly hovers in front of him: symbolical design. Fine Roman worle on sirrd.

87. Cutid with a hound in a leash: very coarse Roman work on dark green quarta crystal, or plasma.

S5. Profile head of a youth on serrd, coarsely cut: part broken away.

S9. Hoad of Pan, with small horns: in the field below is his syrinx (pan-pipes): Roman work on red jasfer, chipped: cf. the small head of Pan on late Macedonian tetradraclums.

90. Gryllus: a parrot standing on a branch: its body is made up of a Tragic and a Comic mask: Roman work on convex chalcatony.

Pliny, Hist. Nat. xxxy. I 14 , uses the word gryllus for a class of grotesque figures first used in painting by Antiphilus of Alexandria. The word also means a cricket, but with regard to gems is used to express any grotesque monster which is made up of several masks or portions of other animals.

91. Comic mask: Roman work on dark olve-green plisma, slightly executed.

92. Comic mask: Roman work on a convex orange sard.

93. Comic mask: Roman work on yellow jasper.

94. Bearded mak head and fimak head, conjoined: Roman work on sard, possibly representing Jupiter and Juno.

95. Scarabacid with a rude representation of some sort of shrine (?) deeply cut on the convex surface of a fine piece of very transparent chalcidony.

96. Threc horsmon wearing high crested helmets: two riding side by side, the third galloping in the opposite direction. Roman work, minutely cut on camelian.

97. Seated female figure with one hand extended over a small circular altar placed in front of a rock, on which stands 
a small shrine; a tree srows out of the rock: rucke Roman work on sart.

9s. Fimali figur fouring a libation(?) on to a small circular altar at the foot of a tree. On the other side of the tree a female, seated in a chair, holds an infant on her knee: very minutely executed: broken in two places; part of the seated figure is missing. This design possibly represents the fostering of the infant Zeus by the Nymphs Adrasteia and Ida, daughters of Melisseus, in the island of Crete. Good Roman work on dark red carnelizn.

99. A mute male figure wearing on his head a petasus, stands holding in his arms a stag with curved horns: below a small figure reaches up towards the stag. Behind the principal figure is the word AVCTVS. The lower part, about a third of the gem, is missing: rude Roman work on arange sard.

Ioo. Two male figures wearing tunics standing, between them an infant is kneeling on the ground: minute, but poor Roman work on camolian; broken. Mr King in his Catalogue, Case I, No. 42, explains this subject as representiner "Diomede and Ulysses debating about the fate of Astyanax"; but the gem belongs to a late period when subjects of that class were no longer selected.

IOI. Nude fimale figure stooping towards a large vase which stands at the foot of a column: behind her is a tree and on the other side a warrior in full armour, with sword and round shield: on orange sart; the upper part broken away. Coarse work very deeply cut. Subject doubtful: a gem in the Jritish Museum (No. 1463) has a similar design.

I02. Full-facid bust of Mercury, wearing the petasus and holding a caduceus: coarse Roman work on dark carnclian: the marks of the drill and wheel are very conspicuous.

I03. Bust of Hapocrates with his finger on his lip; very rudely cut on chalcalony: late Roman work.

IOA. Profile bust of Fufiter Scrapis with the molius on $\mathrm{H}$ his head: in the field the letters $K$. Very good Graeco$\lambda \epsilon$ 
Roman work on saml: it has been reduced in size to fit in a small ring-bezel.

Fitit 1 .

I05. Eagle with outspreat aings; and above, a small bust of Serafis with raliated head; round it is the legend EIC ZEYC CAPAחIC, "One God Serapis." Good Roman work of the second century A.w. On reat jersfer. This type of gem is common; varictics of the inseription are EIC OEOC CAPAMIC, and $E I C Z \Omega N O E O C$, attestations of the Divine Unity, like that of the modern Moslems.

106. Gnostie scariburdid on green plasma: on the front the late Egyptian sun-god Cnoubis, represented as a serpent with lion's head surrounded by rays of light. On the back is the hicroglyphic symbol -fff surrounded by the legend XNDVBIC. The whole is a common type of Egyptian gem during the Roman Gnostic period, 3rd and 4 th centuries A.I. The name of this deity is written variously as XNOY $\phi \mid \Sigma$, $X N O Y M I \Sigma$ and $K N H \Phi$ : he appears to be a late development of the early Egyptian deity Chnemu, the World-Creator or Moulder. He is called "Maker of all things that exist, Creator of things that are, the origin of evolutions, the father of fathers and mother of mothers." He is also "Father of the gods, moulder of men, begotten of the gods, maker of Heaven and Earth and Hell, of water and mountain."

In later times Chnenu became associated or identified with the sun-god Ra and with Osiris. With the Gnostics he was a form of Hor-Apollo-the Demiurgos or Spirit which "pervades the universe." This note I owe to $\mathrm{Mr} \mathrm{E}$. A. W. Budge. The medical properties of this design when engraved on a green jasper or plasma (jaspis) are explained by Galen, Di Simp. Mich. Ix. Sec above, page $1+5$.

107. A cornu-copiec and a small globe: coarse Roman work in banded chalicany.

IOS. A comu-copiar, a call, and a stalk of bcardid what. Minute Roman work in brilliant amethyst.

109. A humanleaded locust, walking with a pole across his shoulder, from which are hung a hare, a rabbit and a lobster; in the field a serpent and a scorpion. Panciful 
Roman work of the first century A.I). on a banded agate. A talismanic gem with magical propertics.

IIO. A hand crtinded: round it the legend MNHMONEYE, on sert: a common type of Roman memorial gem; in many. cases the hand is pinching an ear, which the Romans regarded as the seat of memory; cf. Virgil, Ecl. VI. 3 to 4 , Cynthius an'in a'tlit.

I I I. A grotesque nude figure, walking with a staff, and bearing on his back a dead crane: probably referring to the old story of the battle of the lysmies and the cranes. Minute Roman work on camelim, if antique.

I I2. A man with o mattock breals up the ground at the foot of a cross, on sart: of cloubtful antiquity:

I13. A rude folm-branch: lyy it the letters $E$ : the rest C A

of the inscription is broken away: late Roman work on dark camelian. The inscription was perhaps meant for 'l zoồ wkâ.

I 14. A dolphin sit in a basin on a tall pedestal in the form of a twisted column: the whole is apparently a fountain. Coarse late work on emmelian.

I 15. Male figure standing by a cifpus: very rudely cut on a small pink amctly'st.

I I6. Sarab cut in a fine emerald-culoured flasma; a bead from a necklace with no engraved device.

I 7. Two fragments: sard and three-bunded agate.

\section{MONERN GEMS.}

1. Copy in dark red persti of the celebrated signet of Mibilangilo in the Bibliotheque in Paris: No. 2337 in M. Chabouillet's Catalogue.

The original was engraved for Michelangelo by his friend Picro Maria da Pescia, who worked in Rome for Leo $\mathrm{X}$., and was one of the ablest intrgliateri of the Renaissance. The boy fishing in the crovgte is a rebus of the artist's name Pescia, derived from his birth-place, a smal! town of that name in Tuscany. The main design represents 
a Bacchanalian festival, and contains no less than eleven figurcs-one of the greatest marvels of microscopic workmanship that has ever been produced A great many paste copies of this wonderful gem exist. The original was bought by Louis XIV., with the rest of the important Lauthier collection, and so it passed into the Bibliotheque Royale, where it is still preserved. In the last century it had a very narrow escape of beins stolen. The Curator of the Bibliotheque was exhibiting the royal gems to the Baron Stosch, an enthusiastic collector of engraved stones, when suckenly the Curator observed that Michelangelo's signetgem had vanished, after a suspicious movement on the part of the Baron. The Curator immediately sent for an emetic, and forced Baron Stosch to swallow it; with the fortunate result that in a few minutes the grem was heard to fall into the basin provided for the purpose; see Des Brosses, Lettres sur l'Italic, II. p. $27^{1}$.

2. Fenale hoal in profile in the white layer of an onyr.

3. Fomale full face, wearing a diadem and neclitace; on srey jersper.

4. Irofile bust of a bearded man wearing a tuban, on a very finc blodstone; i.e. green jasper with red spots.

5. Piasemt blowing a cow-horm, on sard.

6. Hate Bacchanal with a thyrsus, dancing, on bandal sard.

7. Earsli's head on dark green chalcedony.

s. Head of 11 . Asripfa; cameo on onjw, good modern work.

9. A ceiled laty standing, holding an urn; camco on sariluny. A poor modern work, probably meant to represent Agrippina with the ashes of Germanicus.

1 IBaron Stosch, who was a IIanoverian spy on the Pretender's domigs abruad, lial a large collection of engraved gems, including some genuine antiques and many fergeries; a resy interenting catalosue wa made of them by Winckelmann, printed at Florence in 1760 . Stusch died in 1757 : he is the shnizs of lope's satire-

"False as his gems, an cankered an his coins."

The stonch gems are now in the berlin cullection, which contains more than sooo gems, antique and moilem. 
10. Head of Ariatue with iny weatle; small camco on any of three strata. One josper layer between two of chaleckeny.

II. Gem from the l'oniatowsti collection. latre figure of Tinus, half draped, seated on a rock, and balancing a stick on one finger. Cupid flying mpward grasps at the stick. In the exigut is the name AYsOY: on a fine large comelian, cut to an octagon shape and mounted ats at rings. What is possibly the original of this design exists in the British Muscum, No. 2296, cut on a bumt chalcidony, a fine gem of the later Renaissance period, inscribed AYAOC, not AYAOY as on the Poniatowski copy. This is an exceptionally fine specimen of the celebrated Poniatowsi gems, which were engraved early in this century by various clever artists, such as P'ichler Jum., Grometti, Cerbara and others, and passed off as antigues by P'rince Poniatowski, who died in $1 \$ 33$. Most of them have, like this gem, the name of a supposed ancicut gem-engraver: this particular name dulus occurs on many of them. The very sraceful dusign on this gem seems originally to have been taken from some Roman wall-painting; the cxecution is very skifful and the design is essentially pictorial in character. As modern works of art many of the l'oniatowsli gems have consiclerable merit, but in style they are very unlike ancient gems. The fact that they were generally accepted as antiques in the early part of this century is a striking example of the low state of architeological knowledge at that time. The nucleus of prince l'oniatowslit's coliection consisted of about 150 ancient gems inherited from his uncle Stanislaus, King of l'oland; by the help of modem engravers the prince increased his collection to no less than 3000 gems. The forged artists' names were mostly added by one clever engraver named Dies. The whole collection was dispersed in 1839 . At one time single examples of the l'oniatowski gems were valued at as much as a thousand pounds, but after their spurious nature was discovered they seldom fetched more than from three to four pounds cach, although, in many cascs, they were really worth far more as exceptionally fine specimens of modern gemcugraving. 


\section{PLATE I. AND II.}

The following Plates are reproductions by the autotype prucess of the most important of the gems in the Fitzwilliam Collection.

As they are taken from impressions of the gems in plaster, they represent the design as it appears on the scal made by the gem; not as it is on the intaglio itself.

For the sale of clearness each gem is enlarged, in linear dimensions, to one and a half times its real size, and also because a reproduction of the same linear dimensions in plano of a rounded surface not only appears but really is smaller than the original. The higher the relief, the greater the loss of visible surface when it is represented in flano.

Plate 1. contains examples of work of the carlier periods, ranging from glandular gems of pre-historic times down to gems of late Greek or Gracco-Roman style.

Plate lI. contains other examples of Graeco-Roman work, together with Roman sems from the period of the Republic down to that of the later Empire.

Though on the whole the process employed in these I'lates is a fairly satisfactory onc, yet it must be remembered that much of the delicate beauty and refinement of modelling in the best of the gems is necessarily lost in the process of reproduction.

The mubers on the I'lates refer to the numbering of the gems in the preceding Catalogue. 

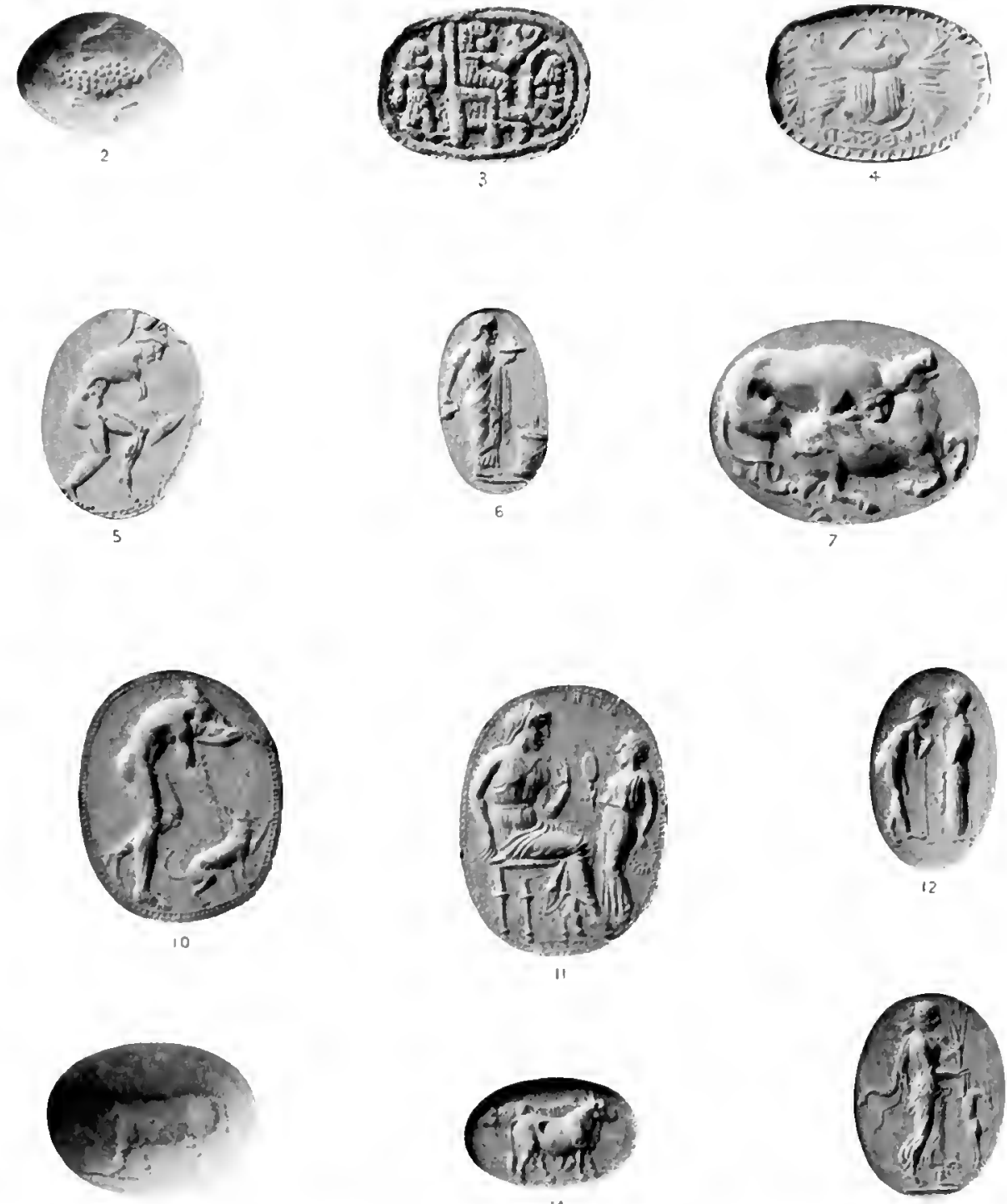

14

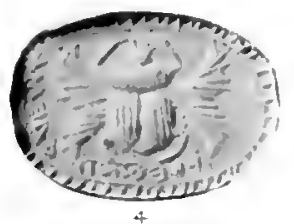

13
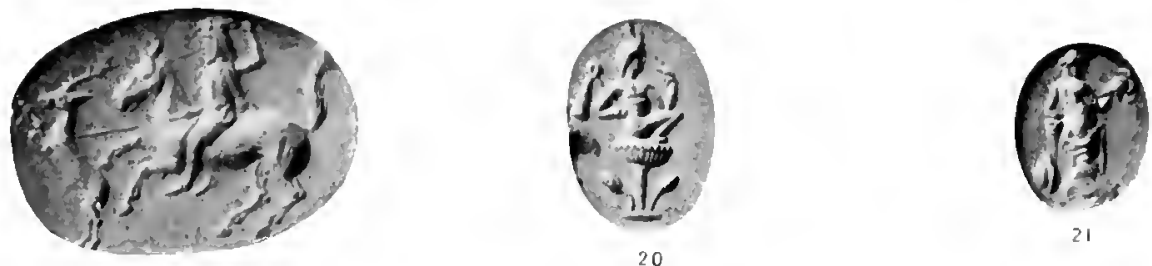

20

21

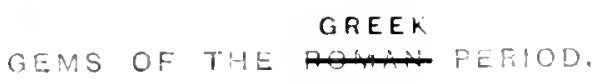



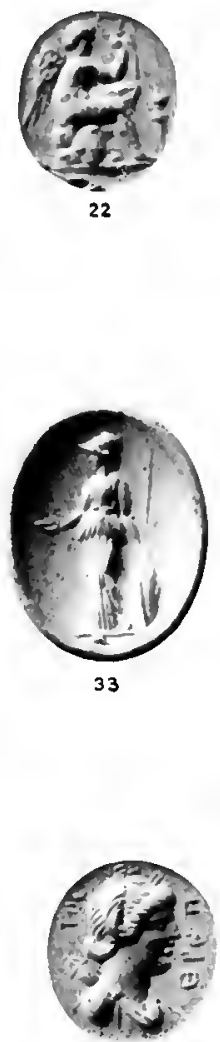

50

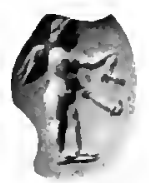

56

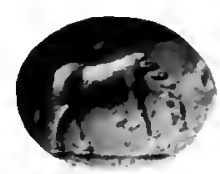

73
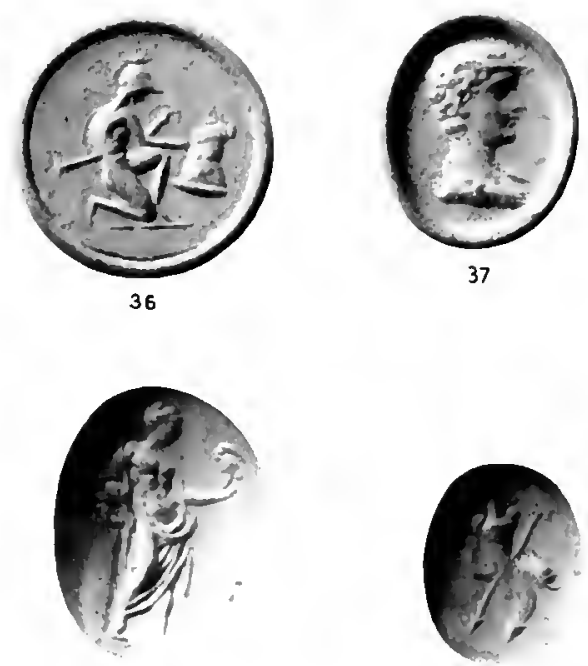

53
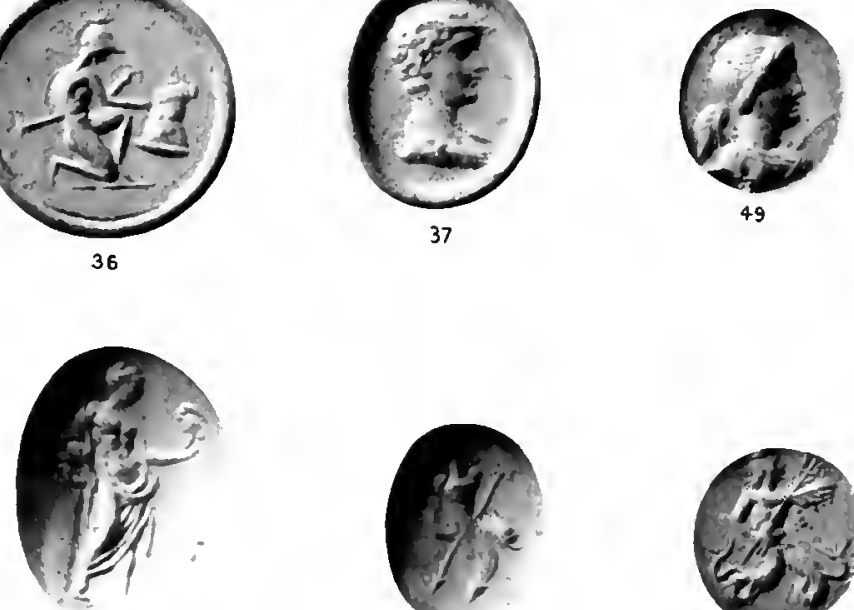

52

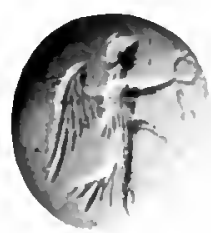

31
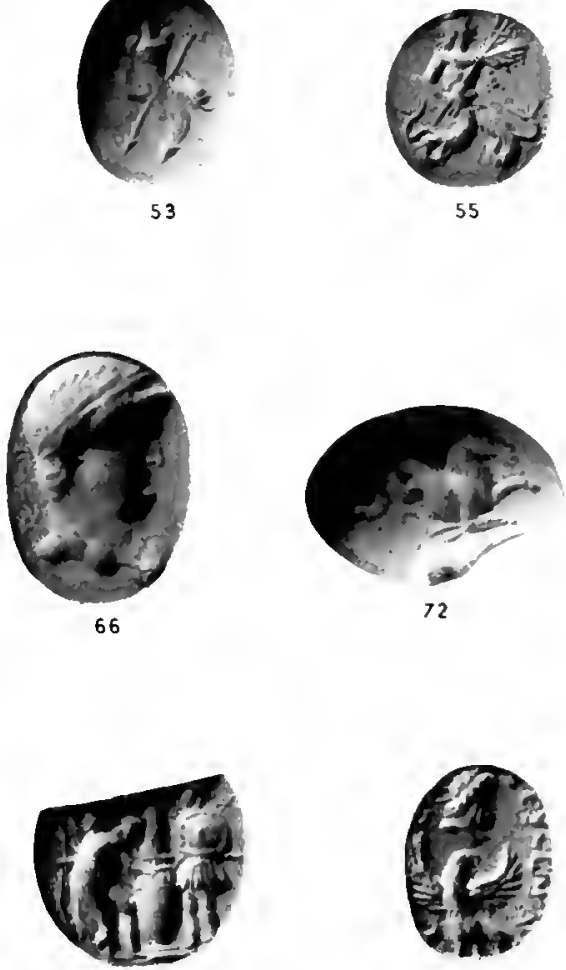

101

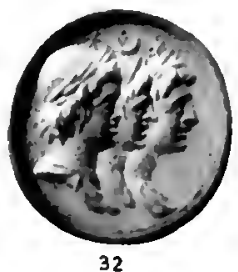

55

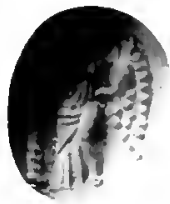

64
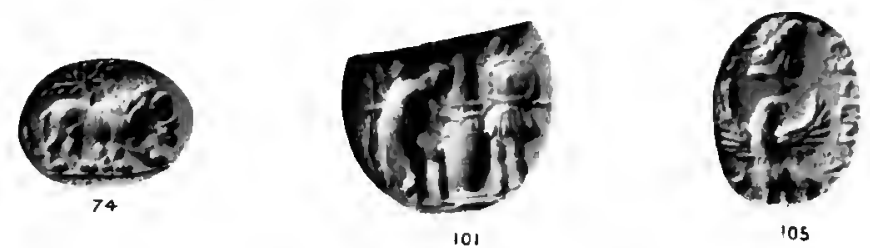



\section{INDEX.}

Aaron's beastplate, Gewe on, 60 note, 131

Almaxas the mystic sureserd, so; the worl, chgraval on gems, 94, .1/ $x, x i$

Abunalantid, Fignte of, on gems, st

Achillen playing the lyex, on at gem, og

Aeropulis of Athens, Discoveries am, 15,26

Allamas, The", 129-131

Acgaeac, Eutycles of, 75

Aegrim, I'luenician searat, found in the Istand of, $1+1,15$, Ats iv

Agate, $1+7$ : large cameo patera of, 62 Agathopus, Gem signeal by, so

Agrippina, on modern cameo, Aft. xis Alexameler, Heat of, on gents, $f 1$; 110 coins of iysimachus, is.; used for signet ly Auguntur, so

Alexandres, Name of, on gems, 82, 8.3 Ambassadors, Gokl rings worn by, =0

Amber, $15+156$; rings mate of, $155 ;$ use in prehintoric times, it.

Amethyst, The, 1+2, $1+3$

Amulet gems, $1+5$

Amymone, Figure of, on cmeralil gem, 40, $13 \%$

Anichini, gem-engraver, 126

Ant, kepresentation of an, Aff, xix; chariot drawn ly lwo ants, Aff. xiij

Antaradus in Phocnicia, "Irittite" signet found at, 10

Anterus, (iems signed by, si

Antiplones, I'assige frum, on scarab ormancuts, 21
Antiphulonthe firace-digyptian panter, inventos of the gryllas, 55

Anteninu l'ius, fortrait licand if, ineal as a seat by l.outs 1., 121

Anthrax, I32

Aphromite representerl on some, to, Ah. xi

Apollo, firones statue of, by lianachus, copied on gemes, +2

Apullu Itelios, I'robable andencentation of, AP. xviii

Apollo saunctumos, Represcutalion of, on gems, $f^{2}$

Apullortoton, fiem of, 68,60

Apullonides, gem-engraver,

Apollonios, fiem signed ly, is

Aputheosis of Augustus, 61; of ficrmanicus, ib.

Aptera, Coin of, y2

Apuamarine, variety of beryl, $13^{6}$

Arcalia, bignext coins of, y?

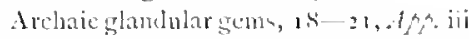

Areiu, hing of Sparta, hignet of, mentioned in a letter, $A$ H. iii

Arialne, lleal of, y2, thp.xav

Arintiplts, lleat of, 15

Aristopluanes, l'assage from, on the custom of securing dours with a seal, , 6 , 37 ; un magic rings, 23

Artancrxes, name of varien, Sianian kings, s'

Artemis, Figure of, on gem, $77-78$. Ath. $x$

Ashmolean museum, fems in, 10, 13 Asklejios, thead of, on germ, 82 
Assyria, Signets of, z--6

Astrion, 132

Astrological gem 4,55

Athemades, Signet signed ly, 73

Athene, Head of, 60,68 ; bust of, 76 ; figure of, $A f t . \mathrm{xv}$

Athenion, Cameo simed by, 84,85

Attalus I1., King of Pergamus, Collection of cngraved gems made by, 33

Attulas, Name of, on ring, Aff. xv

Auguntus, Sardonyx of, 34: Apothersin of, 61: portrait lust of, 63 ; head of, on cameos, 65. $7^{6}, 86$; the sphynx, head of Alexander the Great, and his un $n$ portrait uset an signet by, +9, so

Aulus, Name of, on gems, $S_{2}, . t f p . x x v$ Austria, Eagle of, taken from Oriental device, $11-12$

Balylonian eylinder, Figure of an carly, $4 ;$ cylinclers, produced under Darius and Xerxes, 5

Bacchanal, stpf xais

Bacehus, Figure of, Atph. xii, xvii

baphiom, Lenticular gems discovered at, 20,21

Basalt, I 52, 153: gems made of, 20

beal, King-chaped, Ath xiv

Benn-shaped gems, is

Iielli, Valerio dei, gem-engraver, i 26

Beryl, The, 13 - $3^{3} 8$

Betrothal ring of St Joscph and the Virgin, Supposed, y6

Peverley, Lori, Scipio's ring formurly in the possession of, +7 , Att. xiii

bezel, Meaning of the word, 34

Blowhinone, Tlee, if

Bocthos, Cameo signed by, 85

Boms Eventu, Figure of, s+ thf. aiii

Bow and arrow, Hero with. figured, 26

bow and drill, Illustration of a $\mathrm{man}$ working with, yos

Bracelet, Signet wom as, 3

lirutus, Portrat-head of, on ring, 73

likil, on gem with name of Iyllus, $7 z$; attacked by lion, fthe v; and cow, Ath ix; walking, Ath ax
Cable or guilluche border, 15

Cahochon form of gems. 39

Cacsar, Julins, Gift of ringrgems to the temple of Venus Genitrix hy, $3^{6}$; heat of, on gem, 79 ; Victory on coin of, tfp. xwi

Callaina, The, I +9

Callais, The, 150

Calpumius Sesertn, Gem of, $7+75$

Cameo gems, 5 ) - $\sigma_{5}$

Cameos with artist names, $8+-8 y$

Camiros, Gem in the Fitzwilliam Muscum from, I3, Apf. iv; glass cylinders found in the tomls of, 5

Cannae, Gold rings from, 52

Capma, Goll ring found on the site of the ancient, 73

Caraealla, I'ortrait of, on sap?hire, 132

Carbuncle, The, 13s; I3y; cups of, 139

Carlisle gems in the liritish Nuseum, $+9,78,81,87$

Castel Bolognese, G. da, gem-engraver of the Kenaissance, 126

Castor and J'ollux, Justs of, -Aff. xii

Cellini, benveruts, s6, 127, 133 not:; gent bought by, 135

Centaur, Figure of a wounded, on Greek gem, 28

Cesati, Aless., gem-engraver, $s_{2}, s_{3}$, 126,127

Chaleedony, It+

Chariot drawn by two ants represented on gem, stp, xiii

Charles V., King of Franci, Signet of, 124: cameo given to Chartres Cathedral by, 62

Chaton, Meaning of, 34

Cherpss, Ring of, 31

Chertomesul, King found on the fingers of a Queen of the, 33

Cherulim and palm-tree, 3

Chester collection of signets, 10, I1

Chios, Sphinx on coins of, +9

Christian gemb, Devices on, 57

Claudius, Portrait of, on rings, +2

Clay seals, $5,6,27$

Clazomene, Tetradrachm of, 9? 
Cumulic, Representation of, on Lisyllian gem, $56, .4 f f \cdot x \times i i$

Cinek, Representation of $a$, Aff. aix

Coins, l'ortrats on, $+0,+1$; Artists' names un. $59-96$

Cologne, Gems on shrine at, 124

Colyns, Thomas, Frior of Tywardreth, signet of, $+2,+3$

Cesmic mask, fth. $\mathrm{xx}$

Cincort, Collection of gems in the Temple of, 35,36

Concordia, Figure of, on gems, yt

Condalium, Ncaning of, :1

Comical signets, 6; figures uf, $7-1$; how wurn, 8,9

Constantine, Decalence in time uf, 57

Cornu-cupiae, $A \mathrm{~A} \cdot \mathrm{xvi}, \mathrm{x}$ ii

Corandum (emery), I3.3-1.34

Cow, on gem by Apullonilen, it nele; on gem in Fitzwilliam Mluseum, $A f \hat{f}$. ri

Crab on a gem, Afp. xix

Crete, signed coins of, $y^{2}$

Cronius, gem-congraver, $;$ I

Crystal, ()uart $z$, usel for gems, $25,1+2$, Aff. $v$; stained to imitate jewels, 137 ; cups male of, $I+1-1+2$; used for catutery, $1+1$

Crystalline silica, $\mathrm{I}+0-\mathbf{I}_{\mathbf{4}} \mathbf{2}$

Cupie?, Figures of, on gems, $85.4 A f$ svii, $\operatorname{six}, \mathrm{xx}$

Custus amnuli, Office of, 5.3

Cyanos, real and artificial, 150, 151

Cychnia, Tetradrachm of, 92

Cylinder, Early babylonian, figured, +

Cylinders, I-I6; materials of, 2, 3 ; worn as lracelets and necklaces, 3 , 5 general use of, ih.; how engraved, 3. 4 ; their inscriptions, 4 ; lialylonian, producel moler Jarius and Nerses, 5 ; found in the tumbs of Camirun, th.

Cyprus, eilass ringe from tombs of, 117

Cyrene. Gems lavishly worn in the Greet colony of, 3.3

Cyriac of Ancona, Ancient gem described $l y,-76$
1) actylinticane, $33,3^{6}$

1):rius, lablytenian cylinders proxluced under, 5

Iedicatory incription on gemen ofo

1)examenos, Gicms signed lig, 2s, 72, Ap. vij-ix

Dexilla, leclieation of articlen of juwellery ly, in the larthemsn, s1-32

Diamond (atamas), 129-131

Diamont, lyes of, in fireck statuctec, 130: set in koman rings, 1,31

1)iamond-Point, The, $111-11,3$

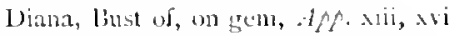

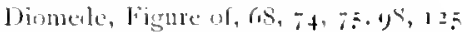

Diomele and Ulysses, ligures of, it. 1ff $\mathrm{xxi}$

Dionysus, lieprescntations of, 24, to, $115, A h \cdot \times$ vii

Dimeuri higured on Runan gems, fis; Aff. xiij

Diuktomriules, Gems signed ly, 71,75 79.86: mosaic signed loy, iy note

bivine Unity, I'rofession af the, on gems, 94

bolphin, kepresentation of $a, 67,1.35$ Ap. sxiii

I) menico de' Cammei, gem-engraver, of the lienaissance, 126

Donatello, atmirer of ancient gems, $\mathbf{1}^{2}+$

Drill, The gem-engraver's, 103 - 10y

Drill-cut scarab, figured, $10 \%$

Eagle represented on jauper, iff $x$ xii ; limperor borne by, 6i ; Jupiter and the, 62; head of, on chalcedony, Aff. xxiv; llying, on a glandular gen, Aff. iii

Ear-rings, Cold, - $-1 \AA \mathrm{f}$. xiv

Ectypae, Cameos, 59

Egy!t, Cylinders usel as signets in, :; their materials, ih.; clay seat found in, 6; scaralis of, unet for sealing bottles, 37; and offerings, 2;

Electra, l'robalile representation of, on gem, Aff. ix

Emerald, The, r.3t-136; ring of Tolycrates, 3.5. (uo) ; portrait of Alevaneler on, it; dolphin on, $13:$; usal ly 
Nero in thentre, 134; ly gemengravers as rest for their eyes, ib.

Emery, Ust of, 104, 107-108; hest, from Naxos, 105, 133

Epicurus, Portraits of on gems, +1

Episcopal rings, 122-123; crozier set with gems, I 23

Epitynchanus, Gems signed ly, $8_{3}$

Eros, Figure of, on gem by l'hrygillos, $91 ;. t h t \cdot x i$ : on ear-rings,.$t h t$ xiv

Eiruscan tombs, Gems from, $+t-t^{6}$; scarab with mele drill-work figureel, 107 ; scarabs, $35-4^{6}$

Euainetos, Coins 1,y, 30, s9, go

Euarchides, Coin signel by, 91

Eucleidas, Coins signel by, yo

Emmenes I., l'ortrait hearl of, $f$ r

Euodos, Fortrait of Julia by, 49, 63 , $74,123,137$

Euphraten Valley, Cylincler signets used primarily by the races of the, 3

Lutyches, Gem sigined by, 75,76

Evans, A. J., on signed cuins, yo

Exakentidas, Coin signed by, gr

Explanatory words on gemu, 9.3

Eecchiel's list of gems, I ro. I 3 I

Facet-cut gems, 39

Fauns on gems, 2f -tht. xvii

Felicitar, Figure of, on gems, st

Felix, Gem signed by, 75

File, Use of the, I13, II ; uscri to test gems, I 37

Fjre drill, $10_{4}$

Fitzwilliam Museum, Catalogue of engravel gems in the, $A p$. iii-xxr

Flamen Dialis, IIollow ring worn by the, 51,52

Foiled gems, $116,1,38$; and pastes, 1 16

Foppa, Amb., gem-engraver, 126

Forgeries of gems, $9 y-102$; of artists' signatures, 72 ; of stones, $117.15+$

Fortnum, Dr I rury, Collection of Chistian rings of, 57

Fortuna, Ninute figure of, Atp. xvii

Francia, Francesco, the painter, Gems ungraval by, 126

Frog engraved on seals, so
Funia, Meaning of, 3t

Gajos, Gem with name of, sy

Gallene, swimming furure of, 7 I

Galvanic rings, $5^{6}$

Ganymerle, Figure of, 127, Aff. xvi

Garnet, The, ${ }_{13} 8$

Gem-engravers, Tools used by the ancicnt, 103-1 $1_{4}$; names of, 66-93

Gem-engraving, The technique of, $103-120$

Gems, Antique, Materials used fur, 129-156; characteristics of ancient, $97-102$; in mediaeral times, $121-$ I 28 ; of the silicon family, $1+0$; engraved grems treated as personal ornaments, I greetings on, 95: artists' names on, 72-75, 09-10z; comparative hardness of, 157 ; inscriptions un, 66-89; polishing of, 114; variety of shapes of, $3^{8,39}$

Germanicus, The Apotheosis of, 61: Heal of, on gem, 83

Cistubar, Figure of, strangling a lion, on a Babylonian cylincler, +

Glandes, sling-bullets, Is

Glantular gems, 18-2 I, Ath. iii

Glass riness, 11 , Aft. xiv

Glass, Various methods of working, 119

Gnaios, signature of, on gem, 75

Gnostic Aeons, Names of the three, on gems, 94

Gnostic belief concerning the Orders of Anguls, ath. $x$, xi

Goat, Representation of a, Aff, xviii

Gold signets, $17,31,73,119-120$; among Tarthenon treasure, 32

Golt, Store of, in throme of Jupiter, 52

Gorgon's head on cameos, 59, 60

Granites, $1: 2$

Greaves, Nethod of fitting, shown on gem, 25, Aff. v

Giteco, Il, S2, I 26

Greece, Common practice of wearing gems in, 33

Greek coins, Indication of Mayistrates" names on, 24; with artists' names, so $-93$ 
Ciret rems, :7-42; suliject on, 24; signct-gems, harlige of owner on. $2,3,2+$

- net of the signet, $22,23,37$

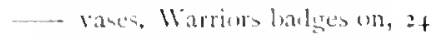

Coectings instribed an gems, 95

firyllus, ligure of a, fhp. wa: nsed for

Konnan signet-gems,

(idilloche border un grems and coins, 15

Iladrian, sale of the collection of erems formed ly. 53

Il aematite, $145,151,152$

llagerai. Gesn of, 66

llaml, A. exteduled, -Afs, sxiii

Ilardness of gems, Table of 157

llarpucrates, figure of, on sems, 55 ; bust of, Ats ani

Ilen-hant figared on cylinkleren, +note

Ilelintrope, the, if

Iletlon. Name of encravel on gems. Sz

lera, lossible repreacentation of, on ring, st; cameo beat of, ARt. Aib av

leraklaea, fironze tables of, 2, 24 ; coin of, 29

llerakleilas, Kings simed ly, 7.

llerakles, liepresentation of, $2_{4}$, tho, 8i, Ah. vi

I Ieralury of anciente, 19-20

Hercules and Cerlems an cameon, s6; bead of, .th x x riii

liero will buw and arrow hgured, an

l lexolutur on signet-chtting, is

bermen, $77,-\%$, 110: bust of, thp. xiv

llermen l'sychopempos on geme, :5;

Ilemphitos, Cameo signet Iy, sh

I limera, Representation of the Nymph, on tetradraclim, 90

linpras, signet-ring made hy the Soplnist, 1 if

ilippocamp, Representation of, on a gem, iff. xviii

Hette signets, 6, 7, 10, 12; huw worn, 7 ; thuir therices, 11

Inore, Representation of $a$, w a gem, Afs xuii, six

llorsemen, Three, figured on camelian, thex
Ilom, Figure uf, used for signcts, represcutation of shox

1 louml, Kunniug, .th six

llunting socmes, represculed an sems, thp. a and $\mathrm{xi}$; on sollit signet from Niyenac, 17

Iyacinthus, Tlue, 1.32

lyllus, frems signed ly, 7 r, 7

Indulgentia, lägure of, on ring, इ+

incoriptions on gems, $6(1-8)$

Invegptisms, Talismanic, ys

10, lleal uf, on gem signed loy llowkouriales, 79

Iron rings, 51 ; used in Kome for letrothal, इ1 noti

Isis, Figure of, on ring, $5 t$; worship of, in Rome, 5

Islaud gems, 1s; their daten, 20: designs. il. ; theis material, a

… scaratix, 1 2: their material, ili.; devices, 1,4, in)

Ismenias, Encrald lunght Iy, to

Isucrates on use of seals, 34

Jasper, It+ I 45

Jewedlers' tricks, It7, ist

Jewellery, Areck, 135, I.36, 138

Jugurtha, Fingraving of the surrender of, used as a signet ly siulla, 53

Iulia, Signed portrait of, Ly Enorlos, 49 , $6.7+12.3,1.77$

Juno, ligure of, +4 is 55 ; lonst of, 63

Jupiter, Figure of, on gems, $48,55,62$, Ath. xii : earlente the xix ; heat of. 6o: head of, bued as a portrait of st Onwakl, 122

Jupitcr Ammon, lleal of, on ring, 54

Jupter Capitolinu, Cems in temple of, 35. $3^{6}$

Jupiter Serapis, liust of $d \hat{\text { th }}$ xxi, xxii Jus annuli aurci, 50-5 I

Kallimachus, said to have first drilled stone, ros

kimmana represented on coin, or

kanachos the seulpter, t2 
Kertch, fiems de. found in tombs at, $60,72,73,4 f t, v i i i, x$

Kimon, Coins by, 30, 80-91

King, C. W., hist of works of, Prof. $x$

kileito, Detication of jewts by, in the l'arthenon. $3 \mathbf{r}-32$

Kihler, Treative of, on scarabs, 4.5

Kreonticlas, Nime of, on searab gem, $67.4 \%$ iv

Lancoun. True pusition of the lost arms of $+2,43$; represented on a gem, 4 ?

Iaplis lazuli, $150,15 \mathrm{I}$; intation of, in jaste, 65

Leake, Cul, Collection of gems and other works of art of, Pref. ix, $x$

Lenticular gems, $18-2 \mathbf{I}$; ditto in collection of $\mathrm{Mr}$ A. I. Lvans, 20 ; ditto showing the use of the wheel, 110

Leo X., gem-collector, 126

Leonario, Camillo, author of a work (m) gems, 126

lumarto da Milano, sem-engraver of the Renaissance, 126

Letters, Precaltions in seal of, 22-23; inseription on seal of, 67

Lima, a gem-engraver's tool, i 13

Lion, Maneless, on gem, Afp.v, vi; representation of a, $A f f$. xix; com. mon in early (jreek art, Aft. v-ri

Lion and Stag on Greek gem, 28, , o

Livia, ligure of, on gem, $6,3,8,3$ : lilock of crystal dedicated by, $1+1$; cameo hual of, on turquirige, 150

Lncust, I mman-headed, Aff. xxii, xxii

Lothaire J., Crystal signet of, 121,122

1.uis 1., Anciont gem nsed as signet by, I 25

Louis IX., Camen given by, 6 t

Luynes, Duc de, Collection of scarah gems maxle by the, it

Lyncurium, variety of amber, I 56

Lysimachus, Ileail of Alexander used on the coins of, fo, 4

Maecenas, lTeal of, 75,77 ; official seal of, 50

Naemals on gems, 24
Magi, Superstitions of the, $\mathbf{I}_{4}$

Masic wheel ("ing), 33

Nagical gems, 123

Nagistrates' names on cuins, 24

Mlagna (iraecia, foll signet-ring flom tombs in, 3 r; ditto signed loy their engravers, 7.3

Magnes, natural loalstone, I

Nagnetite, I5 r, I 52

Han on horseback representel on gem, Aff. ix, $x$

Marc Antony, Device on gold coin struck by, 53; apal coveted by, I $4^{6}$

Marcellus, Dedication of gems in the temple of Apullo l,y, $3^{6}$

Narcus Aurelius, l'ontrait heal of, used as seal by Cliarlemagne, $\mathbf{r} 2 \mathbf{r}$

Maria, Giovansi, gem-engraver, I 26

Narllyorumb gems, 7t note; molern gems among, $12 \mathrm{~S}$

Mars, Representation of, Aff. xv

Massaro, Matteodal, gem-engraver, 126

Maximianus I Terculeus Augustua, Clase cup bearing the name of, 110

Medineral use of ancient gems, 12 I 123: gem-engravers, $124-127$; collections of gems, 124

Medici Family, Wadge of the, 1,3 $\mathrm{r}$

Merlici, Lorenzo de', Name of, on gems, 77 , so; as a gem-collector, $125-126$

Melici, I'iero de', Gems of, 125

Medusa, Iigure of, on cameo, 63 ; hear of, $38,60,64,132,135, A f t, x i v$; Furgel artist's sigmature on gem with head of. 7 ;

Melns, Aphrodite of, +2 noti

Mercury, Figure of, 77,78, iff. xvii; bust of, Aff. xxi

Ietal signets, $17,73,119^{-120}$

Michelangelo, Copy of the signet of, Aft, xxiii, xxiv

Mike, Gem of, $68, A t f$. vii

Mlinerva, Ilead of, on cameo, 86 ; figure of, $4^{8}, 55, A f f$ xiii

Mithradiates, Cullection of Greek gems in kione formerly luelonging to, $3^{6}$; coin portrait of, +1

Mnesarchus the gen-engraver, 70 
Moretti, Mareo, gem-engraver, 126

Moslem signets,, 8

Moulds for paste gems, I I 5

Mune playing on lyre, signed ly Onesas, at Flerence, 80

Mycenae, grems foum in, 17. is; their devices, it.; golul signets from, 17

Naples, latera cames at, 62,63 ; gold signet at, $7, ;$; igneel cameu at, $\delta_{+}$

Naximm, emery, 13.3

Nemesis, Wingeel figure of, $A \beta p$. xvii, aviii

Nero, lortrait of, Asf. xviii; emerald nsed by, in theatre, 134

Veuantos, Coin signed by, 92

Nico, Detication of sem of, in the temple of Aphrodite, $32, .33$

Nicolo, variely of onyx, $1+4$

Nikander, Gem signed ly, it

()bsidian, used for statuces, 1+2; to test gens, 553

Oilo, King of France, Signet used by, 121

Otfa, King of Dircia, Sinnet of, 121

Dnatas, Gem signed by, sy

Ontsas, Gem signed by, so

Opal, The, ${ }_{4} 6$

Onyx, The, $1+6,1+7$

Orestes, Probalite representation of, on gem, Aff, ix

Paconts, fins of Rarhin, Engraved portrait of, on gem, 23

Ialm-branch, iff.xaii

Famphilos, signature of, on amethyst, $79-80$

Pan, Figure of, on com, 92; hearl of, on jasper, $A f f \cdot x x$

Papal rings, 122

raris, Inventory of precious objects in the Sinte Chapelle at, 61 ; gems in the Bibliotherue in, $61,62,7+77$, 79,83 : signet of Nichelangelo in, Anf.xxiii-xxiv

l'aris, Julgment of, cameo signed by Anteros, $8 \mathrm{I}$
Parthenom, fiems deposited in the treasury of, $31-32$

Pasiteles, sculptor and rem-engraver, is

l'uste camens, 64, 65

l'aste gems, The technique of, 114 119; how to distinguish them from real gems, 13.3, I $5+$; materials of, 153; made to imitate crytal, 15.t; Lullules in, it.

l'zul 11., Collection of grems of, 125

Paul I11., I'ofi, Portrait of, 127

l'ebbles, rems shaped like, 18-19; nsed for voting, 107 not

l'egasus, I'robable representati in of, on gum, iff.x

Persephone, llead of, on coin, 91

l'erseus represented on gems, $2+$

l'ersian gems, 6, 7,58

l'eruzzi, a medineval gem-engraver, 124

Pescia, Pitro Maria da, gem-engraver. 126, Aff.xxii

l'halerae cameos, $60,62,6,3,14^{2}$

thanes, Coin of, 67

I'haraoh's signet, 1

l'heilias, Gems of the age of, 28; forged name of, on gems, 93; Atluene of, copiest on gems, Aff. xiii

l'hilemon, signature of, on gem, 80,81

l'hilistion, Coins signed by, 29

l'hiloctctes, Figure of, on cameo, 8

l'huenician gems, 12-16; alevices on scarabs, 1,3-15; scarab figured, 14 ; scaralueoid, Aff iv

Phrygillos, liem and coins with signature of, 9 I

Pisanello, painter and medallist, I27

Piscatoris, Sub annulo, 122

Pistrueci, Benvenuto, 102

Plasma, 145

l'lautus, Passage from, on use of signetimpressions, 22

Pliny on gem-eutting, 106

luison rings, $; 2$

Polish of gens, 114

Polycrates, Signet of, 35, 36, 69, 7o

Pompey, Derices on the signets of, 5.3

Poniatowski collection, Gem from, $A f f$. xxy; its history, ib. 
xisiv

Portland Bane, 11:, 118

Portaits on gense, fo, 4

lottery, disc-stamps used on, 6r: incised lines on, cut with dimond point, 11.3; ormmented with whecl-cut patturns, 119 mot

\section{I'rase, $1+3$}

l'rometheus, leggend of the ring of, so I'rotarchos, Cameo inseribed by, sa

proverlial phrames on gema, ys

"Ptulemies, Cup of the," 62

l'yrgoteles, gentengraver, +1, 70. 7

Pythuloris. Coin signed by, yz

Quartz crystal, $140-1+3$

ka, The Fun-gor, I, 2

kemainance, fiem-engravers of, 126 lings, Giass, ri 7 , Aff. xir: gold, iz, 73,150

lingu, Large numbers of, worn ly ladies of rank. $3, ;$; of the komans described by l'liny, :0

Kock crystal, $\mathbf{I}+\mathbf{I}-\mathbf{I}+3$

kinger, flbf, wignet used by, 122,123

lioma, ligure of. $5.5, .1 \hat{\beta}, x v, x$ vii

lioman denatii, Magistrate inclicated on, 24

— gens, $47-5 ;$; suljects figured on, +4

-. names for rings, : I

use of gems an vignets, fy

loman, kinss selinm worn by the, in ancient timess, 50

_ rignet-gems of the. unew for sealing plaster stoppers of hottles, 37

limi, fios. Ant. de, gem-engraver, 126

lintellim, of sem-engravers, 109

kuby, The, 132, 1,3

Saladin, landge of, I I

Sialus, Fisure of, on gems, st

Samuthrace, the of gold sisnet-rings said to have originated in, 31

Sapor or Shapur, l'ortrat of, on Sasanian genm. 5 sis
INDEX.

Sapphire, The, 1,32; white, 1,3

Sappho, kepresentation of, on Greck gent, $\geq 7$; on vane, il. note

Sapplirus, t 50

Sard uned for ancient engraved gemu, 1 29, $1+3-1+4$

Sarloine, 1+4: gem with Eros cut in, Aft. xi

Sardunyx, The, I 8 , I +9 ; mate up of three stones, 137

Sargun l., Cylinter of, $t$; date of, 5

Samanian gems, st: Aff. xi-xii

Satyr, 1 , represented on gem, 24, Aff. xix; head of a, on cameo, 48

-_ and wine-cup represented on a Greek scarab, 25

Satyreius, gent-engraver, if

Savomarola, Fra Girolamo, Portrait of, by G. delle Carniuble, 126

Saw, used for cutting marlsle. 109

Scarabaeoids in Fitzwilliam Musemm. Aff. iv-viii

Scarabaeus lectle, 1, 2, 2 noti, tho. iv-v

Scaraba, I-16; set as rings. 1, 2; wom round the neck, 2; as charm, 2 note: materials of, z; collection of, in the Fitzwilliam Nusum, 2 wotc; date of the oldest, 2: med as ornament lw the Greek i, 21, 22: uned for sealing planter stoplere of buttles, 37

Scaurus, M. Aenilius, the earlient kinman genr-collecior, 36

Sceptre, Gold, in the liritinh Museum, I $3^{6}$

Scipin Africanms the elder, Sardony worn by, ifs

Scipu, ling of, $+\pi, A$. $x$. xi

Scrpan, Forged name of, on gems, 93

Sculptor ung a drill. represented on Roman relief. 104

Seal, Pasange from Aristophanes on the custom of securing loor with a, 36,37 ; used to secure voting $17 m$, 34 ; ditto wine-jars. 37

Sefficl, Bf, of Chibeste, Alraxay gem ised liy, 123

Selencus 1V., kim of Sprist, lootrait 
hear of, used as a seal ly Ohlo, King of Frantir, 121

Semuter, Cylinder signets used by the, 3 semitic inseription on figured gem. 66 scmom, Inscription on gem of, $6-$ Serapis, Worship of, 55 ; " emerald" statue of, 135 ; bust of, $4 \mathrm{ft}$. xxii

Severus, l'ortrat of, on plasma, $14^{6}$

Sicilian colonies, Early art-rlevelopment of the, 30,31

Sicily, Gems and coins produced hy the engravers of, 29 ; coins of, with artists' names, 89

sigillum, Meaning of, st

Signatures of gem-engravers, $69-y 3$

signet-gems used for sealing plaster stoppers of bottlen, 37

Signet-ring, Names uned for the various parts of a, it

Signets, 1-16; Use of, in wine-cellars, 37; conical, 6; cubical, 1o; circular, I: handled, 9; higured, ro

Silenus, lepresentation of, $A f \hat{A}$.

Silenus mask, Afp. xii

silicon stones, $140-1+9$

Siren, bevice of a, on gem, Att. ix

sirns, IIead of, on grem, हैं

Simaragelus, $134-136$

Socrates, Heal of, (n sems, +1, . Apt. xviii

Silon, Law of, with regard to gems, 22

Solun, Name of, on gुem, is

Sospita, Juno, on coins and gems, t $^{8}$

Suntratos. Cameo nigned by, 87

South Kumington Museum, Waterton collection of rings in the, 53, 5t

sphymx used for a signet, +4

Stanislaus, King of Polund, (jems of, Aff.XXY

Star-apphire, 132

Statues reprenentel on gems, $+2,77$, gy; cut in crystal, obsidian ke. $1+1-1+2$

Steatite, I52; used for earliest scarals, 2 ; and for lingud gemin, 2 I

stelae. Altic, gems with similar designs, $25,-i f t$, vii

suatified itones, $1+1$

II. sulla, rignet uad ly, 5

inrias. Ciem signed lyg, ks, ky

symbolum, Neaning of, 1 : use of, 22

Taghliacarne, gem-engraver, 126

Talimanic inscriptions, gf ; ring . 2.5

Taysetur, Mik, basali from, uncal fir gents, 20; rock crystal from, .tht.

Tests for gems, 153-154; for aldamis, ₹.30; to dintinguibh ancient fronn mulem sems, gí-102

Tenkro, Name of, cut on gem, se

Tharros, ficarals from. It-16

Theles, lleraldic sheld devicen on vane from, it

Theoturus of Samme 35, 60. 70

Theodoton. Coin signet by, 92

Theophrastus on gen-cuting. 1o\%

Thersis. fiem of, 65, 6s

Theneus reprenented on gem, 24, so-si

Threptos, Name of, on gem. Aff. wi

Tooli, inventerl hy Theorlorm, 6g: of gem-engraters, 10,3-120: used ly the Sophline llippias, 114

Topazus, The, I +9; itatues of, w.

Toruss, a gem-engmaer's turl, 10,3 note. 109; a juiner: toul, 69

Trajan, Gems sold hy, $\therefore$

Triton, kepresentation of a. .4h . xit

Trybhon, gem-engraver, $i$ I

Tubular drill, uned for gems, ros

Tukey, Mamner of signing edict by the Uttoman stltans of, 37

Turquoise, The, I +y-1:00

Tympanm of gentcutter, 110

Libses figured on gem. it

Lugrulu-, Meaning of.

Vasari on gem-engraver. 8,3. 126

Vases, Warrior badges on Greek, 24 : artiste names on, y3: incined lines on. $I^{3} 3$

Velia, Coin of, copied on gem, 2y-30

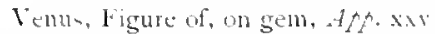

Venus Victrix, Figure of, $13.3,-4 f \hat{f}$. Wi Victory, ligures of $+7.57,87,88,115$ Aft xii, siil. $\mathrm{N}, \mathrm{NH}$ 
Viemna, Great cameo of, 61 ; cames of llerophilus at, $; 6$

Voting-ums sealed up with signets, $3+$

Votive offerings sealed with clay, 37

Vulcan, Representation of, Aff. xvii

Walter, $A b p$. Goid ring of, 123

Waterton collection of rings in the South Kensington Museum, s... it

Westminster Abbey, Ancient gems in, 65

Wheel, The gem-engraver's, son-II I

Wine-cellar, Use of signets $\mathrm{in,}, 37$

Wolf represented on sard, $A$ A . . is
Nerxes, Babylonian cylinders produced under, :

Vouth caressing his log on gem, as on Attic stelae, Atp. vii

Zeus lestroying the fiants, cameo at Naples, $s_{+}$; heal of, on a scarab of the finest style, 27,112

Zeus, Fostering of the infant, Aff. xxi Zeus Lycaeos, llead of, on coin, 92 Zeus Serapis, Ilead of, on gems, 55 , IfA. xxii

FINIS

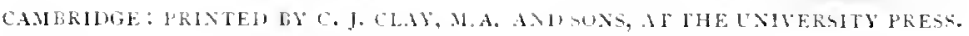




\section{SOME PUBLICATIONS OF \\ THE CAMBRIDGE UNIVERSITY PRESS.}

The Literary Remains of Albrecht Dürer. By IV. M. CoNw.AY. With Transcripts from the British Museum MISS., and Notes by Lind Eckenstein. Royal 8vo. 2ls. (The Edtition is limitid to 500 coptics.)

A Catalogue of Ancient Marbles in Great Britain. By Prof. ADOLF Michaelis. Translated by C. A. Ml. FeNxelt, Litt.I). Royal Sro. Roxburgh (MIorocco back), \&2. $2 s$.

The Types of Greek Coins. By Percy Gardner, Litt.D., F.S.A. With 16 Autotype plates, containing photographs of Coins of all parts of the Greek World. Impl. tto. Cloth extra, fi. IIs.6ul; Roxburgh (Morocco back), f.2. 25 .

Essays on the Art of Pheidias. By C. W.aldstein, Litt.D., Phil.I., Reader in Classical Archrology in the University of Cambridge. Royal Sro. With numerous lllustrations. 16 Plates. Buckram, jos.

An Introduction to Greek Epigraphy. Part I. The Archaic Inscriptions and the Greek Alphabet. By E. S. RonfrTs, il.A., Fellow and Tutor of Gonville and Caius College. Demy Sro. With lllustrations. ISs.

The Woodcutters of the Netherlands during the last quarter of the Fifteenth Century: In 3 parts. 1. History of the Woodcutters. II. Catalogue of their Woodcuts. 111. List of Books containing Woodcuts. By W. M. Coxwar. Demy Sro. ros. Gr.

Euripides. Bacchae. IVith Introduction, Critical Notes, and Archeological lllustrations, by J. E. SANprs, Litt.D., Fellow and Tutor of St John's College, and Public Orator in the University of Cambridge. New and Enlarged Edition. Crown Svo. 12s. 6 .

Ilondon: C. J. CLAY AND SONS, CAMBRIDGE UNIVERSITY PRESS WAREHOUSE.

AVE MARIA LANE. 



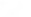


This book is DUE on the last date stamped below. 


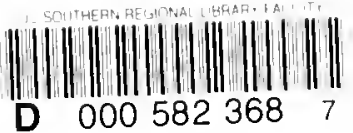

Ai

Librat 
